\title{
PROPOSTA DE INTERLIGAÇÃO DAS GLEBAS DO PARQUE ESTADUAL DE VASSUNUNGA (Santa Rita do Passa Quatro, SP)
}

\author{
VÂNIA KORMAN
}

Dissertação apresentada à Escola Superior de Agricultura "Luis de Queiroz", Universidade de São Paulo, para obtenção do título de Mestre em Ecologia de Agroecossistemas.

PIRACICABA

Estado de São Paulo - Brasil

Fevereiro - 2003 


\section{PROPOSTA DE INTERLIGAÇÃO DAS GLEBAS DO PARQUE ESTADUAL DE VASSUNUNGA (SANTA RITA DO PASSA QUATRO, SP)}

\section{VÂNIA KORMAN}

Engenheiro Agrônomo

Orientadora: Profa. Dra. VÂNIA REGINA PIVELLO

Dissertação apresentada à Escola Superior de Agricultura

“Luis de Queiroz”, Universidade de São Paulo, para obtenção do título de Mestre em Ecologia de

PIRACICABA

Estado de São Paulo - Brasil

Fevereiro - 2003 
Dados Internacionais de Catalogação na Publicação (CIP) DIMSÃO DE BIBLIOTECA E DOCUMENTAÇÃO - ESALQ/USP

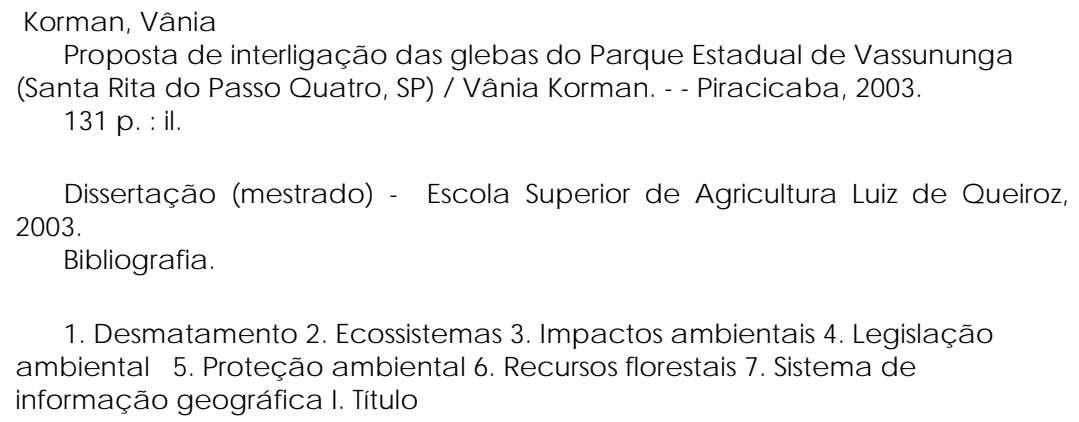

1. Desma ta mento 2. Ec ossistemas 3. Impactos a mbienta is 4. Leg islação a mbiental 5. Proteção a mbiental 6. Recursos floresta is 7. Sistema de informação geográfic a I. Título

CDD 333.75 


\section{Meus agradecimentos}

À FAPESP, pelos recursos concedidos para a realização deste projeto.

À Dra. Vânia Regina Pivello, pela forma profissional e carinhosa com que me orientou e pelos constantes incentivos.

À Dra. Maria Victoria Ramos Bellaster, por ter disponibilizado os recursos do Laboratório de Geoprocessamento do Centro de Energia Nuclear - CENA, USP.

Ao Diretor do Parque Estadual de Vassununga - Engenheiro Heverton José Ribeiro, pelas valiosas sugestões e pelo incentivo à realização deste projeto. Também aos demais funcionários, pelo apoio em campo.

Aos funcionários da Divisão de Dasonomia do Instituto Florestal pela atenção e por terem prontamente disponibilizado fotografias aéreas, imagem de satélite e a carta do IBGE (1971) - Folha Luis Antônio.

À Bióloga Claudia Shida por ter disponibilizado, sem restrições, o banco de dados de sua dissertação de mestrado.

Aos colegas e amigos do Laboratório de Geoprocessamento do Departamento de Ecologia Isotópica, CENA/USP, pelo apoio constante.

A todos os funcionários da ESALQ e CENA.

Ao amigo José Maurício Sforcin por ter se disponibilizado em ler e corrigir a versão final da dissertação e por ser um grande amigo; à Maria Rita Micalli pelo apoio e à Valesca Zipparo pela ajuda de campo.

Aos estudantes de graduação do Departamento de Ecologia do Instituto de Biociências da USP, campus São Paulo: Wenddi P. Burger, Caio F.T. Gadel e Rodrigo Cassola, pelo apoio nos levantamentos em campo.

Agradecimentos Especiais à minha família (minha mãe Adayr S. Korman, minhas tias, irmãos, cunhadas, sobrinhos) e a todos os meus amigos pelo apoio emocional e financeiro. Também, a meu pai Itze Korman, meus avós, tio José Fregonezi e à “Dna.Tuniquinha” (in memorian). A oportunidade de conviver ou ter convivido com vocês sempre fez e faz o meu viver mais suave e feliz. 


\section{SUMÁRIO}

Página

RESUMO …................................................................................... vi

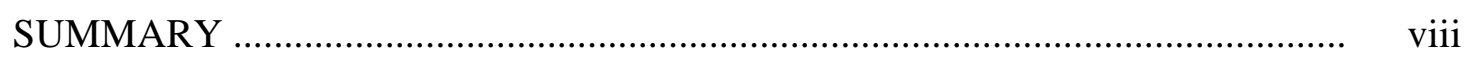

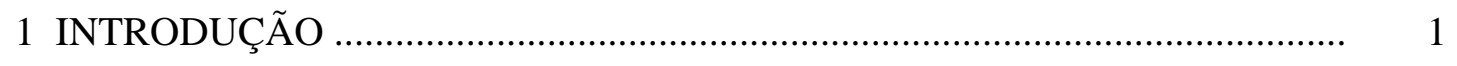

2 REVISÃO DE LITERATURA........................................................................... 4

2.1 A fragmentação de ecossistemas naturais ............................................................ 4

2.2 Estrutura e componentes da paisagem fragmentada ......................................... 12

2.3 Unidades de Conservação e a manutenção da biodiversidade ........................... 21

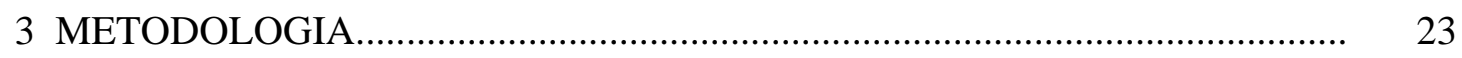

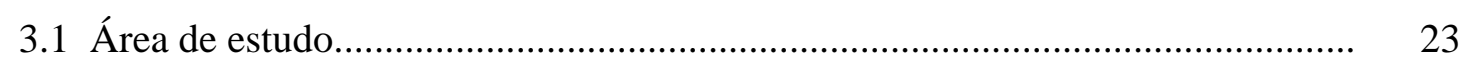

3.2 Diagnóstico ambiental da área de estudo....................................................... 27

3.2.1 Índices da paisagem............................................................................. 28

3.2.2 Diagnóstico de campo dos problemas ambientais decorrentes do uso das

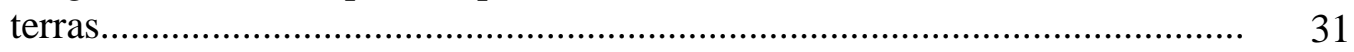

3.2.3 Análise das áreas de preservação permanente dos corpos d’água................... 36

3.2.4 Mapeamento das áreas de risco de erosão no entorno do Parque Estadual de Vassununga........................................................................................... 38

3.3 Propostas de interligação das glebas do Parque Estadual de Vassununga......... 47

3.3.1 Primeira Etapa.......................................................................................... 4

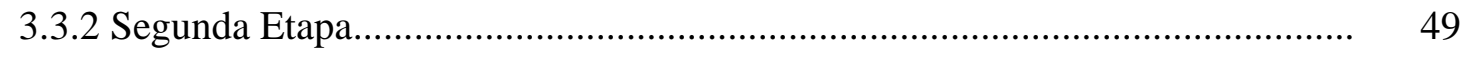

3.4 Propostas para a matriz............................................................................. 51 
4 RESULTADOS E DISCUSSÃO _.................................................................. 53

4.1 Diagnóstico ambiental da área de estudo.......................................................... 53

4.1.1 Índices da paisagem................................................................................. 57

4.1.2 Diagnóstico de campo dos problemas ambientais decorrentes do uso das

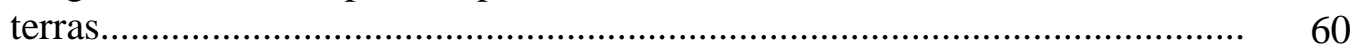

4.1.3 Análise das áreas de preservação permanente dos corpos d’água .................. 75

4.1.4 Mapeamento das áreas de risco de erosão no entorno do Parque Estadual de Vassununga........................................................................................... 78

4.2. Propostas de interligação das glebas do Parque Estadual de Vassununga.......... 83

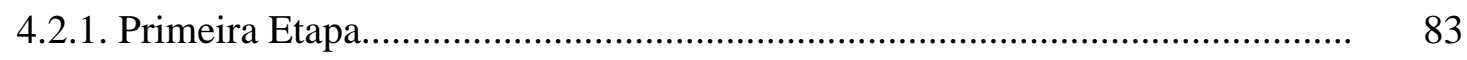

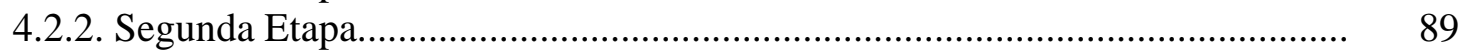

4.2.3. Propostas para a matriz ….................................................................. 109

5. CONCLUSÕES

REFERÊNCIAS BIBLIOGRÁFICAS …....................................................... 122 


\section{PROPOSTA DE INTERLIGAÇÃO DAS GLEBAS DO PARQUE ESTADUAL DE VASSUNUNGA (Santa Rita do Passa Quatro, SP)}

Autora: Vânia Korman

Orientadora: Prof. Dra. Vânia Regina Pivello

\section{RESUMO}

O fato dos ecossistemas nativos do estado de São Paulo estarem fragmentados faz com que as unidades de conservação públicas desempenhem papel vital na conservação da biodiversidade.

O Parque Estadual de Vassununga (PEV), localizado em Santa Rita do Passa Quatro, SP, possui área total de 2069,24 ha, porém, dividido em seis glebas distintas. A gleba Pé-de-Gigante é a única composta por fisionomias de cerrado, desde campo cerrado até cerradão, e uma pequena área composta por floresta estacional semidecidual. As demais glebas (Praxedes, Maravilha, Capetinga Leste, Capetinga Oeste e Capão da Várzea) são compostas por floresta estacional semidecidual. Esta unidade de conservação, sob a administração do Instituto Florestal/SMA, abriga alta diversidade de espécies da fauna e flora silvestres, incluindo os mais belos exemplares de jequitibá-rosa (Cariniana legalis) e várias espécies da fauna silvestre ameaçadas de extinção, como o lobo guará (Chrysocyon brachyurus) e a onça parda (Puma concolor). Sua contribuição também se faz pela recarga de aquífero, em uma região dependente de água subterrânea. 
O presente estudo visou identificar as áreas potenciais de interligação das glebas do PEV, utilizando recursos de um sistema de informação geográfica, bem como indicar propostas e procedimentos para o uso e a ocupação das terras no entorno, considerando os elementos estruturais da paisagem (matriz, fragmentos de habitat e corredores).

Diagnósticos em campo foram realizados com o objetivo de verificar alguns dos impactos ambientais que ocorrem no entorno do PEV, confrontando o uso atual das terras com a legislação ambiental brasileira. Análises de métricas da paisagem e um mapa de risco potencial de erosão, utilizando a Equação Universal do Solo (EUPS), também foram desenvolvidos.

A análise da área de estudo revelou que o Parque Estadual de Vassununga localiza-se em uma paisagem bastante fragmentada, com uma baixa porcentagem de habitats naturais, e tem sido pressionado pelas atividades antrópicas que ocorrem no entorno. A aplicação da EUPS indicou que as áreas de maior risco potencial de erosão localizam-se próximas aos mananciais e ao longo dos cursos d'água.

Estes resultados foram importantes no direcionamento das propostas para o aumento da conectividade da matriz e de interligação das glebas do Parque. As propostas foram divididas em duas etapas: 1. a adequação ambiental das áreas de preservação permanente previstas na legislação e, 2. a interligação das glebas entre si e a outros fragmentos remanescentes por meio de corredores e pontos de ligação, restaurando-se áreas degradadas, protegendo os recursos hídricos, acompanhadas com propostas de manejo para a proteção dos ecossistemas do PEV e de mudanças no uso das terras.

A interligação das seis glebas do Parque Estadual de Vassununga, por meio de corredores e stepping stones, bem como o uso racional das terras em seu entorno, são medidas fundamentais para a manutenção e conservação de seus ecossistemas e da biodiversidade de toda a região.

Palavras chave: conectividade, corredor, conservação, paisagem fragmentada 


\section{PROPOSAL FOR THE INTERCONNECTION OF THE VASSUNUNGA STATE PARK FRAGMENTS, STATE OF SÃO PAULO, BRAZIL}

Author: Vânia Korman

Adviser: Prof. Dr. Vânia Regina Pivello

\section{SUMMARY}

The native ecosystems in the São Paulo State are very fragmented, therefore, the network of natural preserves becomes essential for the conservation of the remaining biodiversity.

The total area of the Vassununga Park, in Santa Rita do Passa Quatro municipality, São Paulo, Brazil, is 2069,24 hectares, but divided in six independent fragments - one of them covered mostly by savannah and the others of seasonal forest.

These 6 fragments of Vassununga Park, shelter a high diversity of species, including the most beautiful and old jequitibá trees (Cariniana legalis) and several threatened species of animals, such as maned wolf (Chrysocyon brachyurus) and cougar (Puma concolor). This Park also holds an important contribution towards recharging the aquifer, in a region very dependent on underground water.

The aim of this study was to identify potential areas to link the fragments of the Park, using Geographic Information System, as well as to indicate proposals for a better use of the lands around the Park considering the structural elements of landscape (matrix, habitat fragments and corridors). 
Field diagnoses were carried out, in order to detect the main impacts in the surrounded matrix and to confront the actual land use with Brazilian environmental legislation. Some spatial indices of the landscape were calculated and a potential soil loss map, using the Universal Soil Loss Equation (USLE), were also developed.

The analysis of the studied area revealed that Vassununga Park is located in a very fragmented landscape, with a low percentage of native ecosystems and it has been submitted to pressures caused by human activities in the surrounding areas. The application of the USLE showed that the highest risk of potential erosion is close to the watershed and rivers. These results were important to direct proposals for the interconnection of the Park fragments, first by the regularization of the preserved areas according to the Brazilian legislation and secondly by indicating the most adequate sites to install corridors and stepping stones, restoring damaged areas and protecting water resources and the ecosystems of Vassununga Park, followed by suggestion of land use changes.

The connection of the six fragments of the Vassununga Park, through corridors or stepping stones, and also the sustainable use of land surrounding it, are very important procedures for the biodiversity maintenance of this Park and region.

Key words: connectivity, corridor, conservation, fragmented landscape 


\section{INTRODUÇÃo}

Em decorrência do aumento da fragmentação e degradação da cobertura florestal nativa do estado de São Paulo, o desenvolvimento de estudos e de novas tecnologias visando o manejo e a conservação dos ecossistemas nativos é crucial. Dados da Secretaria Estadual do Meio Ambiente revelam que restam apenas $9 \%$ da extensão original dos ecossistemas do domínio da Mata Atlântica (incluindo as Florestas Estacionais). Em relação às fisionomias do Cerrado, estas ocupam extensão de apenas 1,17\% de sua área original (São Paulo a, b, 1997).

A excessiva fragmentação submete os ecossistemas nativos aos efeitos de borda, ocasiona perda de espécies e altera fatores ambientais, como o clima regional e regimes hidrológicos (Viana, 1990; Ogata 1997).

$O$ estímulo às pesquisas sobre atividades humanas adequadas para as áreas tampão, reintrodução de espécies, estabelecimento do traçado de corredores de conexão, principalmente em áreas com a presença de obstáculos antropogênicos, são algumas das medidas para vencer a fragmentação e obter a conectividade dos habitats, a diversidade genética, a viabilidade de espécies nativas e o controle de espécies exóticas (Foreman et al., 1993).

No Brasil, as unidades de conservação públicas são as que mais têm representado o papel fundamental na conservação e preservação dos recursos naturais. Mas estas unidades também encontram-se isoladas em paisagens fragmentadas e sofrendo pressão das áreas de entorno, comprometendo a integridade de seus ecossistemas e de suas funções ambientais. Um exemplo desta realidade é o Parque Estadual de Vassununga (PEV), localizado no 
município de Santa Rita do Passa Quatro, região noroeste do estado de São Paulo. Mesmo exercendo papel fundamental na conservação de ecossistemas ameaçados, o PEV vem sofrendo, ao longo dos anos, forte pressão antropogênica.

Diante de um processo acelerado de degradação e inserido em uma paisagem fragmentada, a interligação de suas glebas, com a implantação de corredores e pontos de ligação e propostas de manejo para o uso das terras do seu entorno, é fundamental para reverter os efeitos negativos decorrentes da fragmentação e do uso inadequado dos recursos naturais.

Com o objetivo principal de indicar propostas para aumentar a permeabilidade entre as glebas do PEV e a conservação de seus ecossistemas e dos recursos naturais da área de estudo, este trabalho foi dividido em duas etapas.

A primeira delas consiste em conhecer as áreas do entorno do Parque, com o objetivo de subsidiar as propostas de interligação das glebas e de proteção dos recursos naturais da área de estudo. Após o conhecimento e caracterização da área de estudo, desenvolveu-se a segunda fase, com indicação de propostas de interligação das glebas do PEV e manejo da matriz circundante.

O conhecimento do entorno das glebas do PEV (primeira fase), foi obtido por meio de: a) diagnóstico em campo dos problemas ambientais decorrentes do uso das terras, verificando-se as atividades que estão em desacordo com a legislação ambiental e/ou as atividades que contribuem para a degradação das glebas do PEV e dos ecossistemas naturais da área de estudo; b) quantificação das áreas de preservação permanente (APPs) dos corpos d'água que estão degradadas e/ou estão sendo irregularmente ocupadas com atividades agropecuárias, por meio de imagens de satélite e sistema de informação geográfica; c) cálculo de índices da paisagem para avaliar o grau de fragmentação da vegetação nativa e isolamento dos fragmentos remanescentes; d) mapeamento das áreas de risco potencial de erosão, 
visando a recuperação ou restauração dessas áreas para serem incorporadas aos corredores de interligação ou às áreas do PEV.

Após caracterização e diagnóstico da área de estudo, realizou-se a segunda fase deste trabalho: o mapeamento das propostas de interligação das glebas do PEV, acompanhadas de propostas de manejo ou de alteração do uso das terras para as áreas de entorno.

As propostas de interligação foram divididas em duas etapas:

Primeira Etapa: Interligação das glebas do PEV, considerando apenas o cumprimento da legislação ambiental. Esta etapa propõe o aumento da conectividade da paisagem e a proteção aos mananciais e corpos d'água, por meio da restauração de áreas legalmente protegidas - áreas íngremes, topos de morro e zonas ripárias.

Segunda Etapa: Proposta de interligação das glebas do PEV por meio da restauração de áreas degradadas e manejo de elementos estruturais da paisagem, entre os quais: as próprias glebas do PEV, com indicação de propostas para diminuir os efeitos de borda e a conservação de seus ecossistemas; corredores ripários, outros corredores entre fragmentos de fisionomias de vegetação natural e pontos de ligação (stepping stones).

Propostas de manejo da matriz que possam adequar os usos das terras ao redor das glebas e interromper ou alterar as atividades que, direta ou indiretamente, contribuem para a degradação dos ecossistemas naturais da área de estudo, também fizeram parte desta etapa. 


\section{REVISÃO DE LITERATURA}

\subsection{Fragmentação de Ecossistemas Naturais}

No contexto da conservação biológica, a fragmentação florestal é definida como uma separação ou desligamento não natural de áreas amplas em fragmentos espacialmente segregados, promovendo a redução dos tipos de habitat e a divisão dos habitats remanescentes em unidades menores e isoladas (Harris \& Silva-Lopez, 1992).

Collinge (1996) concluiu que as conseqüências primárias da fragmentação dos habitats naturais são: a perda de espécies de plantas e animais nativos, a invasão por espécies exóticas, o incremento da erosão do solo e a perda de qualidade dos recursos hídricos. Para a autora, a magnitude e extensão dessas alterações na paisagem são influenciadas pelo tamanho, conectividade, forma, contexto e heterogeneidade dos fragmentos de habitat.

Pesquisas realizadas na Amazônia Central revelam que a fragmentação interfere nas variáveis microclimáticas das vegetações nativas. Estas, por sua vez, alteram a distribuição das espécies, como mostram estudos conduzidos em fragmentos florestais com espécies de aves e pequenos mamíferos (Laurance \& Bierregaard Junior, 1997; Bierregaard Junior \& Stouffer, 1997).

Apesar da fragmentação não atingir a fauna de maneira homogênea, pelo fato dos animais utilizarem os recursos ambientais de forma diferenciada, Zanzini (2001) cita dois efeitos interativos que podem incidir sobre os animais: 
(i) a dificuldade das espécies em manter populações mínimas viáveis, e (ii) a inclusão de algumas populações em vórtices de extinção. O autor define vórtice de extinção como sendo a diminuição progressiva do tamanho de uma população, cujo destino é a extinção, relacionada à variação demográfica, fragmentação, depressão endogâmica e habilidade de adaptação.

Duas teorias básicas têm norteado pesquisas sobre fragmentação e fornecido hipóteses passíveis de serem testadas em estudos aplicados: a teoria de biogeografia de ilhas e a dinâmica de metapopulações. Estas teorias foram a base para muitos dos atuais princípios da conservação biológica, incluindo o uso de corredores para aumentar o fluxo da flora e fauna (Forman, 1997).

No contexto da fragmentação de habitats, a teoria da biogeografia de ilhas tem guiado estudos sobre a influência do tamanho do fragmento de habitat e o seu isolamento. Esta teoria postulou que o tamanho de uma ilha oceânica e sua distância de uma fonte continental de espécies colonizadoras determinaria o número de espécies presentes na mesma. Consequentemente, ilhas pequenas tendem a conter menos espécies que ilhas grandes, apresentando taxas de extinção mais elevadas. Ilhas mais próximas de uma fonte de colonizadores podem ser capazes de abrigar um número maior de espécies devido às taxas mais altas de imigração. Com base nesta teoria, pressupõe-se que, otimizando a habilidade das espécies de movimentarem-se por entre as "ilhas", aumentarse-ia a taxa de imigração destas espécies e, por fim, o número de espécies ocupando esta ilha (MacArthur \& Wilson, 1967; Collinge, 1996; Forman, 1997; Louzada et al., 2001; Zanzini, 2001).

A Teoria de Metapopulações tem focalizado a atenção na conectividade e intercâmbio entre populações espacialmente distribuídas. Metapopulação pode ser definida como a série de populações de organismos co-específicos (populações vizinhas), existindo ao mesmo tempo e ocupando, cada uma, áreas diferentes. Algumas dessas populações estariam em declínio, extinguindo-se local e temporariamente, enquanto outras aumentariam demograficamente, realimentando as primeiras. Esta teoria foi originalmente 
concebida para descrever e predizer a dinâmica de populações de espécies ocupando naturalmente fragmentos de habitat (Collinge, 1996; Gustafson \& Gardner, 1996; Forman, 1997).

Um questionamento comum em relação à aplicação terrestre da teoria de biogeografia de ilhas é o fato de a matriz entre ilhas de habitat não ser tão hostil como a água do mar e, também, as diferenças de escalas das distâncias entre as ilhas oceânicas e terrestres. Além deste fato, a matriz da paisagem entre as ilhas de habitat não é homogênea e há pouco conhecimento sobre a dinâmica de movimento dos organismos entre estas ilhas (Gustafson \& Gardner, 1996; Forman, 1997). A dificuldade na aplicação de modelos com base na teoria de metapopulações reside no fato de diferentes organismos perceberem a escala e o grau de heterogeneidade dentro de uma mesma paisagem de diferentes formas; por exemplo, alguns habitats podem parecer, para determinadas espécies, hostis ao movimento, enquanto que outras espécies podem ser favorecidas por estes mesmos habitats (Gustafson \& Gardner, 1996).

Alguns dos impactos da fragmentação de habitats, que podem contribuir para a redução das populações, são: redução no tamanho do fragmento e alteração em sua forma, efeito de borda e o isolamento e perda de habitats. Estes impactos estão descritos abaixo, lembrando que essa divisão em itens é apenas didática, uma vez que os impactos da fragmentação são interativos:

a) Efeitos de borda: o limite entre duas ou mais comunidades vegetais distintas pode ser definido como sendo a borda, e a área de transição entre as comunidades vegetais que faz fronteira é o ecótono (Murcia, 1995; Zanzini, 2001). As mudanças que ocorrem no ecótono, como alteração na composição de espécies e nas condições ambientais, são os chamados efeitos de borda (Odum, 1986).

A borda natural é formada pelo encontro de comunidades vegetais naturais distintas e pode refletir efeitos positivos sobre a diversidade de animais silvestres na paisagem (Odum, 1986; Zanzini, 2001). Porém, a borda antrópica 
geralmente apresenta as seguintes características: é um ecótono induzido, formado por pastoreio excessivo, manejo da vegetação, plantio de culturas, incêndios, erosão, desmatamentos e outras atividades humanas, promovendo efeitos negativos no ecossistema, como a extinção de determinadas espécies e o favorecimento de outras mais generalistas (Zanzini, 2001). A criação de muitos fragmentos pequenos e com muitas bordas leva à homogeneidade da paisagem, promovendo a diminuição na diversidade de espécies, podendo afetar a dinâmica de plantas e animais, com reflexos na sustentabilidade dos ecossistemas naturais (Odum, 1986; Ogata, 1997).

Murcia (1995) classifica três tipos de efeito de borda em fragmentos:

- efeitos abióticos: são alterações físicas ou microclimáticas decorrentes da criação de uma borda. O aparecimento de uma borda aumenta a incidência de luz e, consequentemente, a temperatura aumenta e a umidade relativa diminui; além da velocidade do vento ser superior.

- efeitos biológicos diretos: são alterações na abundância e distribuição de espécies, causadas diretamente pelas alterações físicas próximas à borda (efeitos abióticos). Estas alterações na quantidade de luz, umidade, temperatura e vento podem afetar de forma significativa as comunidades de plantas e animais (Murcia, 1995; Collinge, 1996);

- efeitos biológicos indiretos: os efeitos acima descritos envolvem, por sua vez, mudanças nas interações entre espécies, como a predação, aumento nos níveis de parasitismo, de herbivoria e na dispersão de sementes.

Em regiões tropicais, os efeitos de borda decorrentes da fragmentação dos habitats naturais têm promovido impactos negativos sobre muitas espécies. Por exemplo, logo após a abertura de áreas de pastagem na Amazônia Central e conseqüente fragmentação florestal, ocorreu um rápido desenvolvimento de espécies pioneiras, como a Cecropia spp, nas bordas dos fragmentos de floresta, alterando a composição e diversidades de espécies no fragmento (Sizer \& Tanner, 1999). 
Laurance \& Bierregaard Junior (1997) demonstraram em estudos realizados em florestas tropicais (Amazônia Central e Queensland, Austrália) que os efeitos de borda podem operar em diferentes extensões: mudanças microclimáticas parecem influenciar uma zona de 15 a 60 metros de largura a partir da borda da floresta. Os autores enfatizam que uma implicação chave destas pesquisas é que zonas tampão ao redor das reservas naturais devem ser largas o suficiente para absorver ao máximo os efeitos de borda e, apesar dos avanços nos estudos sobre os efeitos de borda, muito há que ser aprendido, especialmente nos trópicos.

b) Redução no tamanho e alterações na forma do fragmento. Quando analisamos estes aspectos, duas perguntas devem ser respondidas acerca do que seria melhor: 1) Fragmentos de vegetação nativa pequenos ou grandes? 2) Um único fragmento grande na paisagem ou vários pequenos fragmentos? Forman (1997) conclui que pequenos fragmentos propiciam benefícios diferentes dos fragmentos grandes e deveriam ser analisados como um suplemento (e não um substituto) dos grandes fragmentos. É possível supor que uma "paisagem ótima" possui fragmentos grandes, suplementada com pequenos fragmentos dispersos por toda a matriz. Alguns dos valores ambientais dos fragmentos grandes e pequenos são relatados pelo autor:

$\Rightarrow$ Fragmento grande: fornece proteção da qualidade da água para aqüíferos e lagos; mantém conectividade para a rede hidrográfica de pequena ordem; mantém habitat para manter populações de espécies de interior; mantém área central e área de refúgio para vertebrados que requerem grandes áreas de vida e "buffer" (zona tampão) contra a extinção durante processos de mudanças ambientais.

$\Rightarrow$ Fragmento pequeno: fornece habitat e ponto de ligação para espécies dispersoras e para a recolonização após a extinção de espécies de interior; aumenta a densidade de espécies; aumenta o número de populações de espécies de borda; promove a heterogeneidade da matriz; contribui para a 
diminuição de processos de erosão e propicia cobertura para fuga de predadores e habitat para espécies restritas a pequenos fragmentos (espécies que não sobrevivem em fragmentos grandes).

Metzger (1999), revisando vários autores, enfatiza que a área do fragmento é, em geral, o parâmetro mais importante para explicar as variações de riqueza das espécies. A riqueza diminui quando a área do fragmento é menor que a área mínima necessária para a sobrevivência das populações (sendo que esta área mínima irá variar em função da espécie). O autor descreve alguns dos impactos causados pela redução da área do habitat para a fauna, a saber: (i) efeito de borda e a consequente alteração na composição das espécies; (ii) desaparecimento de recursos, refletindo no aumento da competição intra e entre-espécies; (iii) desaparecimento de espécies-chave, aumentando a probabilidade de espécies dependentes também serem extintas (como o mutualismo planta-animal); (iv) diminuição na riqueza de espécies, quando a área do fragmento reduzido ultrapassa a área mínima necessária para a sobrevivência das populações.

De acordo com Collinge (1996), a forma de um fragmento pode ser descrita de maneira simplificada, por meio do cálculo da taxa perímetro/área. Como exemplo, um fragmento de habitat quadrado de 100 ha apresentará uma taxa perímetro/área e proporção de área nuclear maiores do que um fragmento retangular de mesma área. Fragmentos com bordas altamente irregulares e alteradas terão, provavelmente, uma maior troca de nutrientes, materiais e organismos com os habitats adjacentes, comparando-se com aqueles que apresentam bordas menos alteradas.

Quanto ao tamanho do fragmento, Collinge (1996) considera que fragmentos grandes são mais heterogêneos do que pequenos fragmentos, por possuírem maior variedade de tipos de solo, variações topográficas e um número maior de tipos de habitats. Pesquisas revelam a importância do tamanho dos habitats para a avifauna das florestas temperadas e tropicais. $O$ número de espécies remanescentes em fragmentos florestais isolados diminui 
com o decréscimo de área desses fragmentos, e as espécies mais vulneráveis ou sensíveis a esta diminuição no tamanho do habitat são mais especializadas em seus habitats do que as generalistas. Em relação à flora, a autora cita como exemplo espécies de plantas que se reproduzem de forma vegetativa e, desta forma, movimentam-se gradualmente ao longo da paisagem. Estas espécies são, provavelmente, mais aptas a persistirem em fragmentos maiores do que em pequenos fragmentos, onde a colonização será limitada pela fragmentação do habitat.

Comparando fragmentos da floresta Atlântica de diferentes tamanhos (5 a 7.900 ha), Tabarelli et al. (1998; 1999) verificaram que fragmentos menores (< 20 ha) diferem significativamente de fragmentos maiores na diversidade de espécies da flora e fauna. A proporção de árvores com frutos dispersos por aves ou mamíferos diminui em pequenos fragmentos $e$ isto pode refletir no desaparecimento de muitos vertebrados. Os pequenos fragmentos são também mais perturbados, apresentando alta densidade de cipós, lianas e bambus.

Segundo Chiarello (2000), na região de Ribeirão Preto, SP, que teve a sua vegetação natural fragmentada principalmente pelo cultivo intensivo de canade-açúcar, a manutenção de pequenos fragmentos de vegetação natural representa refúgio indispensável à fauna silvestre. Em um fragmento de 150 hectares de floresta estacional semidecídua, foram registradas 20 espécies de mamíferos, incluindo espécies raras e ameaçadas de extinção, como a onça parda (Puma concolor) e o lobo-guará (Chrysoicyon brachyurus), e 49 espécies de aves, sendo a maioria das espécies típicas de ocorrência em áreas abertas e em bordas de florestas. Estes resultados demonstram que fragmentos com esta magnitude (150 ha) são refúgios para a fauna nativa da região.

c) Isolamento e perda de habitat: o isolamento e a perda de habitat representam, talvez, a ameaça mais severa para a diversidade biológica do planeta. Para fragmentos florestais, o grau de isolamento determinará, em parte, o rigor das mudanças na composição da comunidade ao longo do tempo, 
após a fragmentação (Laurance, 1991; Lima \& Gascon, 1999). Segundo Metzger (1999), o isolamento interfere na riqueza das espécies por diminuir o potencial de imigração, dependendo do arranjo espacial dos fragmentos de habitat e das características do ambiente entre os fragmentos.

Zanzini (2001), revisando alguns autores, lista algumas das razões que podem levar ao declínio ou à extinção local de populações que residem em fragmentos isolados, entre as quais: (i) determinadas espécies necessitam de mais de um local para desenvolver suas atividades, como a busca de alimento, cuidados com a prole; (ii) os recursos (alimento e água) não estão disponíveis em um só local dentro da paisagem, variando de local para local, durante as diferentes estações do ano; (iii) as espécies necessitam de diferentes locais para sobreviverem às variações climáticas que ocorrem durante o ano; (iv) a capacidade de movimentação dos animais entre diferentes locais dentro da paisagem é dificultada, comprometendo a viabilidade das metapopulações.

Uma conseqüência imediata da perda de habitats pode ser a extinção de espécies endêmicas (Meffe \& Carroll, 1994). Outra conseqüência, mais generalizada, é o desaparecimento de espécies que mantêm grandes áreas de vida e territórios (áreas defendidas contra competidores ou invasores) (Zanzini, 2001). O desaparecimento de certos animais pode favorecer a presença de outros, como ocorre no sistema presa-predador, onde a ausência do predador pode permitir a proliferação da presa. 


\subsection{Estrutura e componentes da paisagem fragmentada}

Sob o ponto de vista ecológico, a paisagem é definida como uma unidade ambiental heterogênea, constituída por um mosaico de unidades ou partes interativas de habitat (Forman, 1997; Zanzini, 2001). A estrutura da paisagem pode ser definida pela área, forma e a disposição espacial das diferentes unidades da paisagem que a constituem. A estrutura interfere na permanência das populações na paisagem, uma vez que a sobrevivência dessas populações não depende unicamente dos processos que ocorrem dentro de cada unidade da paisagem, mas também, da intensidade de movimentação dos organismos entre as unidades, a qual pode ser influenciada pelo tamanho e proximidade das unidades da paisagem (Metzger, 1999; Zanzini, 2001).

Uma paisagem fragmentada possui elementos básicos - a matriz, as unidades de habitat e os corredores de vegetação entre as unidades (ou corredores de ligação) - que podem ter importância relativa e diferente para a conservação da biota e possibilitar graus variados de interação:

MATRIZ: a matriz é uma área heterogênea, contendo uma variedade de unidades de não-habitat, que apresentam condições mais ou menos favoráveis às espécies do habitat estudado (Metzger, 1999).

Em muitas regiões tropicais, já utilizadas pelo homem, a matriz é composta de áreas agrícolas e pastagens. Em regiões naturais, livres da ação humana, normalmente a matriz pode ser representada por grandes extensões de formações vegetais contínuas, como florestas, cerrados ou campos (Louzada et al., 2001; Zanzini, 2001).

A matriz inter-habitat inibe, em geral, os deslocamentos dos organismos, sendo esta ação mais ou menos intensa em função da permeabilidade da matriz e da capacidade de deslocamento das espécies. A permeabilidade é, portanto, influenciada pela presença de pequenas unidades de habitat naturais que se encontram dispersas na matriz, promovendo a permanência ou o 
deslocamento de algumas espécies silvestres (pontos de ligação, de parada ou stepping stones) e o grau de resistência que as unidades constituintes da paisagem oferecem ao deslocamento das espécies (Metzger, 1999).

Estudos sobre a influência da vegetação de entorno em fragmentos florestais na Amazônia sugerem que a regeneração da floresta propicia uma zona tampão mais eficiente contra o efeito de borda do que pastagens. Este efeito de borda pode penetrar mais no interior dos fragmentos que fazem divisa com estas áreas de pasto (Laurance, 1999; Mesquita et al., 1999).

O fato de a matriz exercer papel importante na dinâmica das comunidades da fauna, a avaliação na conservação de reservas e remanescentes florestais será determinada não apenas por fatores intrínsecos, como o tamanho e forma do fragmento, mas também, pela matriz de entorno, o qual determina sua conectividade com outras áreas florestais (Laurance \& Laurance, 1999).

A matriz determinará, em grande parte, o grau de isolamento das populações nativas nas manchas de vegetação, pois a movimentação da fauna dependerá, em grande escala, de quão abruptas são as diferenças entre a matriz e as porções de habitat isoladas. A fauna que consegue colonizar a matriz apresenta, geralmente, adaptações especiais e amplos limites de tolerância (Gascon et al., 1999).

UNIDADES DE HABITAT: as unidades ou porções de habitat são áreas inseridas na matriz e podem ser desde fragmentos de floresta (em uma matriz de áreas agrícolas) até clareiras (em uma matriz de floresta). As unidades de habitat podem ser ordenadas de acordo com sua origem e fatores determinantes da sua presença, como por exemplo: (i) Porções de habitat natural: fragmentos de vegetação que foram deixados como remanescentes no processo de ocupação e uso das terras (Forman, 1997; Zanzini; 2001). Laurance \& Bierregaard Junior (1997) relatam que estes fragmentos são importantes para os estudos relativos ao melhor desenho dos fragmentos (área e forma), implantação de reservas ecológicas e conservação das espécies; (ii) Porções de distúrbio: áreas que sofreram alterações, em paisagens cuja matriz 
é constituída por ecossistemas naturais (Zanzini, 2001). Pode-se formar porções de distúrbios em função de quedas de árvores, queimadas, erosão, desmatamentos. Estas porções podem representar habitat para as espécies oportunistas e a colonização por espécies vindas de outros ecossistemas; (iii) Porções de habitat introduzido: são áreas de culturas agrícolas, culturas de espécies florestais exóticas, gramíneas exóticas e outros tipos de áreas introduzidas, inseridas em uma paisagem (Zanzini, 2001). O papel ou a influência dessas porções de habitat introduzidos para a manutenção da biota original em regiões tropicais é ainda pouco conhecido (Laurance \& Bierregaard Junior, 1997; Louzada et al., 2001).

- CORREDORES E PONTOS DE LIGAÇÃO (“Stepping Stones”): Utilizados como estratégia conservacionista desde o início do séc. $X X$, particularmente para aves, os corredores têm sido ferramentas usuais na conservação da biodiversidade e nos esforços para mitigar a fragmentação (Hess \& Fischer, 2001).

Conforme a Lei 9985/00, que institui o Sistema Nacional de Unidades de Conservação da Natureza, os corredores ecológicos são "porções de ecossistemas naturais ou seminaturais, ligando unidades de conservação, que possibilitam o fluxo de genes e o movimento da biota, facilitando a dispersão de espécies e a recolonização de áreas degradadas, bem como a manutenção de populações que demandam, para sua sobrevivência, áreas com extensão maior do que aquela das unidades individuais" (Ministério do Meio Ambiente, 2000).

Jordán (2000) considera como corredor ecológico uma área que conecta ou interliga fragmentos, possibilitando, para uma determinada espécie, a migração entre estes fragmentos. $O$ autor acrescenta que os corredores são componentes básicos das paisagens de metapopulações, uma vez que conectam populações locais e podem reduzir as taxas de extinção.

Pontos de ligação (stepping stones) são pequenas áreas de habitat dispersas na matriz (Metzger, 1999), que ajudam nos processos de migração, 
mas não oferecem recursos suficientes para a sobrevivência das espécies em longo prazo. Cercas vivas, faixas de quebra-ventos e árvores isoladas que fornecem alimento, abrigo ou locais de pouso e nidificação são alguns exemplos de pontos de ligação na paisagem (Jordán, 2000).

No Brasil, o Programa Piloto para a Conservação das Florestas Tropicais Brasileiras (IBAMA, 2002b), em fase inicial, definiu cinco corredores na região Amazônica e dois na área da Mata Atlântica. Com a assistência técnica e financeira dos países do G-7, da Comissão das Comunidades Européias e dos Países Baixos, extensas áreas foram mapeadas e classificadas de acordo com os valores biológicos, grau de ameaça e cenários sociais e institucionais que indicariam o grau de sucesso e retorno do investimento na conservação. Os critérios utilizados para selecionar os sete corredores incluíram: (i) riqueza das espécies nos corredores, considerando os números absolutos e relativos das espécies presentes na área do corredor em relação à biodiversidade regional; (ii) diversidade de comunidades e de ecossistemas nos corredores e nas áreas que interligam; (iii) grau de conectividade; (iv) integridade e tamanho das áreas de apoio e (v) espécies endêmicas presentes nos corredores.

Devido ao fato da migração ser fundamental para a maioria das espécies, em ambientes alterados ou não, estudos sobre corredores são importantes para o entendimento dos processos ecológicos e para os objetivos conservacionistas (Jordán, 2000). Autores como Hess \& Fischer (2001), Jordán (2000) e Collinge (1996), enfatizam que o uso dos corredores por animais silvestres pode variar de acordo com os padrões de forrageamento das espécies, com o tamanho de seu corpo, o tamanho da área de vida útil, a mobilidade e o comportamento social. Hess \& Fischer (2001) enfatizam que um corredor, quando planejado para uma função específica, pode servir, muitas vezes, também para outras funções de forma não intencional.

Laurance \& Laurance (1999), observando seis espécies de mamíferos arbóreos em remanescentes de floresta tropical, em Queensland, Austrália, sugerem que remanescentes lineares, floristicamente diversificados e 
apresentando pelo menos de 30 a 40 metros de largura, podem funcionar como habitat e, provavelmente, como corredores de movimento para a maioria dos mamíferos arbóreos daquela região.

As faixas de vegetação nativa são designadas, muitas vezes, como sendo elementos lineares da paisagem ou corredores, geralmente ao longo de cursos d'água. Neste caso, o traçado dos corredores ripários sempre considera importantes funções ecológicas, como a proteção da qualidade da água, e o provimento de habitat para a fauna, facilitando o movimento de organismos entre unidades remanescentes de habitats nativos (Collinge, 1998).

Em regiões em desenvolvimento, como algumas regiões da bacia Amazônica, a retenção de faixas de floresta ao longo dos córregos e rios pode ser uma estratégia-chave para ajudar a manter a conectividade dos ecossistemas em paisagens dominadas pelo homem (Laurance \& Laurance, 1999; Lima \& Gascon, 1999).

De acordo com Tiebout III \& Anderson (1997), o uso de corredores não será uma solução geral para o problema da redução antropogênica da conectividade enquanto alguns problemas-chave de desenho logístico não forem resolvidos, como a geometria dos fragmentos, produzindo variações na conectividade, e o número de fragmentos vizinhos, ou seja, a quantidade ou porcentagem de habitat natural necessária para a manutenção da biodiversidade. Os autores acrescentam ainda que organismos de baixa dispersão que se especializam em habitats sucessionais transitórios podem depender essencialmente da conectividade do habitat para manter a viabilidade populacional. Animais especialistas, que vivem em paisagens mal conectadas, apresentam uma menor probabilidade de colonizar um novo local quando o seu habitat deixa de ser adequado. Em contraste, os generalistas, que vivem em paisagens bem conectadas, geralmente colonizam uma nova área quando necessário.

Uma crítica contra os corredores é a relativa falta de trabalhos aplicados que demonstrem a sua eficiência no aumento da conectividade. Porém, segundo Lima \& Gascon (1999), estudos recentes têm se direcionado a este aspecto. 
Os corredores podem ser descritos de acordo com suas funções ambientais (Forman, 1997; Hess \& Fischer, 2001), entre as quais:

a) Habitat. Exercendo a função de habitat, o corredor é uma área com a combinação apropriada de recursos (alimento, abrigo) e condições ambientais para a reprodução e sobrevivência das espécies. Se um corredor propicia um habitat apropriado, facilitará também a dispersão. No contexto da conectividade regional, diversos autores enfatizam que os corredores devem ser mais largos, podendo sustentar uma ampla gama de espécies em uma escala de tempo anual ou mesmo por décadas ou séculos, cumprindo, desta forma, a função de habitat. Porém, verifica-se a escassez de pesquisas que apontem o quão largos devem ser os corredores.

b) Condutor ou "Dispersor" (Conduit): a habilidade dos animais em moverem-se através de um corredor de um local para outro é básica em todas as definições de corredores. Esta é a função de "condutor", que inclui o fluxo para a migração sazonal de determinadas espécies, para o forrageamento, a exploração e a procura de parceiro para a reprodução. Alguns autores, como Clergeau \& Burel (1997) e Hess \& Fischer (2001) utilizam o termo link ou conectividade (linkage) ao invés de "corredor" para tornar claro seu foco na função de condução (conduit function) e no aumento da conectividade da paisagem.

A função de conectividade de um corredor, fundamentada nas Teorias da Biogeografia de Ilhas e de Metapopulações, está relacionada à facilidade com que as plantas e animais se movimentam em ambientes fragmentados. Segundo Hess \& Fischer (2001), a complexidade está no fato de que uma paisagem linear, com perspectiva humana de conectar fragmentos, não aumentará, necessariamente, a conectividade para outras espécies, pois cada espécie possui histórias de vida e necessidades de habitat diferentes. Para os autores, a maioria dos corredores exerce mais de uma função, mesmo que tenham sido planejados apenas para exercer uma função. Em decorrência das múltiplas e complexas funções que um corredor pode exibir, é extremamente difícil descrevê-las de forma sucinta. A função do corredor como condutor para 
uma espécie, pode ser habitat para outra e uma barreira para uma terceira espécie.

c) Filtro e Barreira: o termo filtro implica em algum nível de permeabilidade e geralmente está associado com zonas ripárias e qualidade da água. Uma "faixa filtro" ou "zona tampão" é, por exemplo, a vegetação ripária adjacente aos cursos d'água, ou outros sistemas aquáticos, destinados à remoção de nutrientes, sedimentos e poluentes, provenientes do escoamento superficial, antes de atingirem os ecossistemas aquáticos.

O termo "barreira" implica praticamente em impedir, bloquear. Como exemplo, temos as rodovias, que geralmente são barreiras para o fluxo da fauna silvestre. Segundo Collinge (1996), há estudos objetivando mitigar este efeito, utilizando túneis, passagens subterrâneas, pontes e outros.

d) Fonte e Sumidouro: a dinâmica das populações de animais silvestres na paisagem pode depender de unidades de habitat adequadas e inadequadas. $O$ destino de uma população na paisagem pode depender do sucesso reprodutivo dos indivíduos que ocupam unidades de habitat de boa qualidade em sobrepujar o fracasso reprodutivo dos indivíduos que ocupam unidades de habitat de má qualidade. Este conceito é chamado de dinâmica de fontes e sumidouros (Zanzini, 2001; Meffe \& Carroll, 1994). Determinados autores consideram que corredores precariamente projetados, podem agir como sumidouros de determinadas populações devido à ampla exposição dos animais nas bordas, deixando-os suscetíveis aos predadores residentes na matriz e à competição com espécies generalistas. Um exemplo de corredor com a função de sumidouro seriam aqueles que exercem a função de filtragem de poluentes e sedimentos, protegendo os ecossistemas aquáticos (Zanzini, 2001). A Figura 1 ilustra, resumidamente, as seis funções do corredor: 


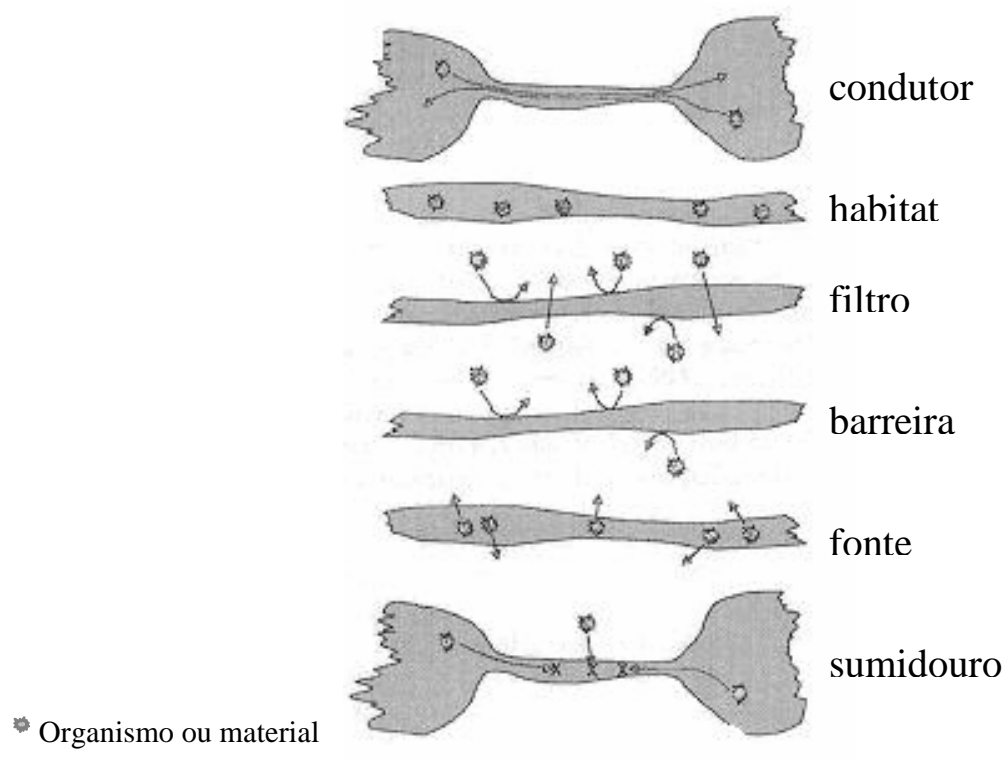

Figura 1 - Funções dos corredores: Condutor - organismos passam de um lugar para outro, mas não residem dentro do corredor; Habitat - Organismos podem sobreviver e reproduzir-se no corredor; Filtro - somente alguns organismos ou materiais podem passar pelo corredor; Barreira - Organismos ou materiais não podem atravessar o corredor; Fonte - Organismos ou materiais provem do corredor. Sumidouro: organismos ou materiais entram no corredor e são destruídos (Adaptado de Hess \& Fischer, 2001).

As opiniões sobre os corredores são diversas, havendo argumentos a favor e contra o seu uso. Alguns dos aspectos negativos e positivos relacionados por Nohlgren \& Gustafsson (1995), são: (i) aspectos negativos: risco de disseminarem incêndios, doenças, espécies exóticas; exposição da fauna e flora a fatores abióticos (efeitos de borda); exposição da fauna silvestre aos caçadores, além de atuarem como barreiras ou filtros para algumas espécies e (ii) aspectos positivos: aumentam a taxa de imigração para fragmentos isolados, permitindo o re-estabelecimento de populações extintas localmente e, desta forma, podem prevenir a depressão endogâmica; propiciam o aumento na área de forrageamento para espécies que possuem ampla área de vida útil; aumentam a variedade de habitats e de estágios sucessionais acessíveis às espécies que requerem esta maior variedade para os diferentes estágios ou 
atividades de seus ciclos de vida; promovem benefícios para a qualidade da água e para a diminuição da erosão do solo; podem ser utilizados para fins educacionais e como reservas de espécies, enquanto a matriz está se regenerando (por exemplo, no corte de florestas plantadas).

Embora estudos revelem que os corredores podem permitir o deslocamento de organismos, pólen e sementes entre áreas ecologicamente isoladas dentro da paisagem, suas funções e importância relativa para a manutenção da biota são ainda pouco conhecidas (Beier \& Noss, 1998).

Analisando os elementos da paisagem acima descritos (matriz, unidades de habitat e corredores), conclui-se que estes elementos influenciam na conectividade da paisagem, ou seja, na capacidade desta em facilitar o movimento dos organismos. Aumentando-se ou mantendo-se a conectividade da paisagem, é possível reduzir a extinção de espécies e prevenir a depressão endogâmica em fragmentos isolados (Lima \& Gascon, 1999; Noss, 1987; Bennett, 1990; Henein \& Merriam, 1990; Meffe \& Carrol, 1994).

Para Metzger (1999), o manejo dos elementos estruturais da paisagem, com o aumento da permeabilidade de suas unidades, é uma estratégia importante para o aumento da conectividade estrutural. A conectividade estrutural ou espacial relaciona-se ao arranjo espacial dos fragmentos, densidade e complexidade dos corredores e à permeabilidade da matriz (grau de resistência das unidades da matriz aos fluxos biológicos). Por outro lado, a conectividade funcional é avaliada pelos fluxos de disseminação ou pela intensidade de movimento inter-habitat dos organismos. Ainda, a conectividade estrutural pode ser utilizada para inferir a conectividade funcional. Portanto, em alguns casos, em função do tipo de deslocamento das espécies, a estrutura espacial tem pouca relação com a conectividade funcional. $O$ conceito de conectividade é essencial na medida em que a sobrevivência das espécies em habitats fragmentados depende da capacidade destas espécies em atravessarem as unidades da matriz. 


\subsection{Unidades de Conservação e a manutenção da biodiversidade}

A perda de áreas naturais e a consequente fragmentação da paisagem afetam seriamente a manutenção da biodiversidade. A biodiversidade refere-se não somente ao número de espécies existentes, mas também à variedade de formas de vida, à diversidade genética, incluindo a diversidade de ecossistemas e de funções ecológicas, fornecendo benefícios econômicos diretos, em termos de alimentação e medicamentos, e ingredientes funcionais para os ecossistemas naturais (Forman, 1997; Fontes, 2001).

Outro importante valor da biodiversidade e de sua conservação para usos futuros é a própria reabilitação de ambientes degradados pelo uso inadequado do solo, construção de barragens e rodovias, e a exploração mineral (Rosado \& Carvalho, 2001).

A criação de unidades de conservação (UCs) tem sido uma das principais estratégias mundiais de conservação da natureza e, consequentemente, da biodiversidade. Um dos principais objetivos da criação destas unidades é assegurar a conservação ou a preservação dos ecossistemas nativos (dependendo da categoria na qual está inserida a unidade - reserva biológica, parque, área de proteção ambiental, etc) (Lei Federal 9.985, de 18 de julho de 2000).

O Brasil possui atualmente 248 Unidades de Conservação Federais (lista atualizada em 06/01/2003), administradas pelo IBAMA - Instituto Brasileiro de Proteção dos Recursos Naturais (IBAMA a, 2002). No Estado de São Paulo, há 56 UCs, administradas pelo Instituto Florestal/Secretaria do Meio Ambiente (Instituto Florestal, 2002).

A maioria das UCs encontra-se sob forte pressão das áreas de entorno. Pires et al. (2000) relatam que, nas áreas problemáticas para o Estado de São Paulo, o componente vegetacional natural encontra-se na forma de fragmentos, isolados por atividades humanas que aceleram os processos de degradação dos recursos naturais. De acordo com os autores, essa situação torna-se mais 
preocupante quando se analisa a integridade dos fragmentos representados por estas Unidades, em função de seus tamanhos reduzidos e das várias pressões desenvolvimentistas às quais as mesmas estão sujeitas.

A criação e proteção das Unidades de Conservação por leis e decretos, desconsiderando os problemas e situações da região às quais estão inseridas, como o grau de isolamento, o desenvolvimento urbano-industrial, a expansão agrícola e a poluição da região, faz com que a maioria destas UCs esteja protegida na forma de um decreto ou lei, mas sem cumprir de maneira efetiva o objetivo para o qual foram criadas: a manutenção da biodiversidade. 


\section{METODOLOGIA}

\section{1 Área de Estudo}

Foi estudado o entorno das glebas do Parque Estadual de Vassununga (PEV), na região nordeste do estado de São Paulo, município de Santa Rita do Passa Quatro, SP, e abrange as microbacias hidrográficas do ribeirão Vassununga, dos córregos Rico e Paulicéia e parte da microbacia do córrego Bebedouro - todos afluentes da margem direita do rio Mogi-Guaçu - totalizando 53.203 ha (Figura 2). A delimitação desta área considerou o fato das glebas do Parque Estadual de Vassununga estarem inseridas nestas microbacias.

De acordo com levantamentos topográficos, realizados pelo Instituto Florestal, nos anos de 1998, 1999 e 2000, o Parque Estadual de Vassununga (PEV) apresenta área total de 2.069,24 ha, distribuídos em seis glebas: Capão da Várzea (12,10 ha), Capetinga Oeste (327,83 ha), Praxedes (152,75 ha), Maravilha (127,08 ha), Capetinga Leste (236,56 ha) e Pé-de-Gigante $(1.212,92$ ha) (Ribeiro, H.J. com. pes.). 


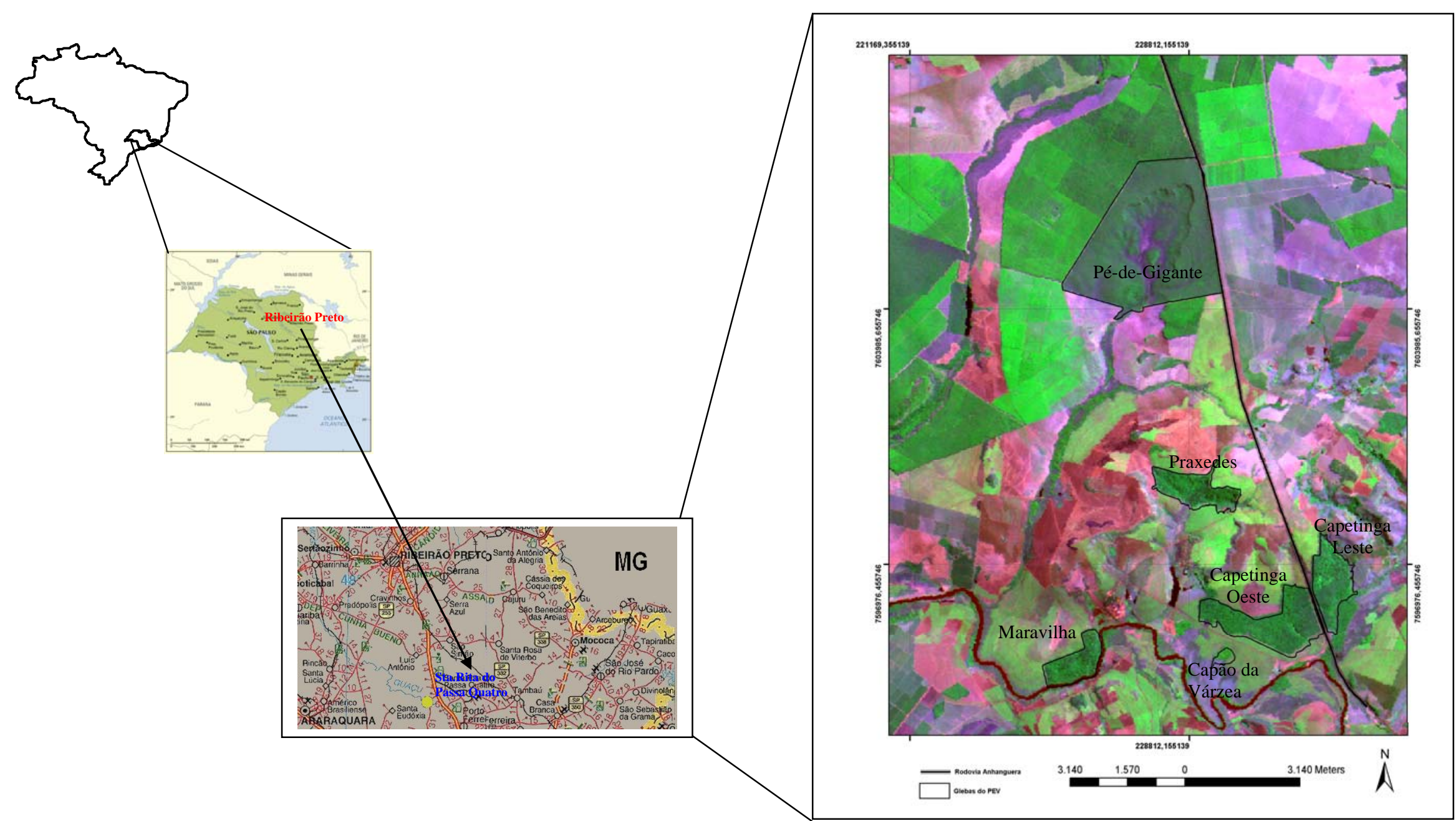

Figura 2 - Localização regional e municipal do Parque Estadual de Vassununga e a delimitação de suas glebas em imagem de satélite Landsat $7 \mathrm{ETM}^{+}$(2001). 
O PEV foi criado em 26 de outubro de 1970, pelo Decreto Estadual $52.546 / 70$, abrigando em suas glebas diversas formações de vegetação. A gleba Pé-de-Gigante é a única composta por fisionomias de cerrado, desde campo cerrado até cerradão, e uma pequena área composta por floresta estacional semidecidual. As demais glebas são todas compostas por floresta estacional semidecidual, sendo que, as glebas Praxedes, Capetinga Leste e Oeste e gleba Maravilha são famosas por possuírem jequitibás rosa milenares (Cariniana legalis [Mart.] O. Kuntze, Lecythidaceae). Estudos demonstram que estas florestas apresentam altos índices de diversidade de espécies vegetais, muitas raras (Martins, 1979; Batalha, 1997), porém, encontram-se muito degradadas.

O clima da região, segundo a classificação de Köeppen, é do tipo Cwag', temperado macrotérmico, moderadamente chuvoso, com inverno seco não rigoroso. A temperatura média anual é de $20,8^{\circ} \mathrm{C}$. O período de chuvas vai de dezembro a fevereiro, com média de $254 \mathrm{~mm}$ e o de estiagem de junho a agosto, com média de 30,8 mm (Setzer, 1966 in Shida, 2000; Instituto Florestal, $\mathrm{s} / \mathrm{d})$.

A área de estudo está situada na província geomorfológica das Cuestas Basálticas, onde predominam rochas sedimentares mesozóicas, caracterizadas como pertencentes às formações Botucatu e Pirambóia, e de rochas intrusivas básicas tabulares. As altitudes da região variam entre 600 a 780 m (IPT, 1981; Martins, 1979; IBGE, 1971; Instituto Florestal, s/d).

A vegetação predominante na região são as fisionomias savânicas, como o campo cerrado, campo "sujo", cerrado sensu stricto, fisionomias florestais, como a floresta estacional semidecidual, floresta ribeirinha (ripária ou mata ciliar), além de campos úmidos (em áreas de várzea) (Martins, 1979; 1993; Batalha, 1997). Segundo Kronka (1998), as formações de cerrado no estado de São Paulo não são contínuas, ocorrendo como encraves em meio à floresta mesófila (Mata Atlântica). 
Em relação à fauna existente na região, um levantamento preliminar realizado no PEV e Estação Ecológica Jataí - que se encontra apenas 3,0 km distante e possui, predominantemente, fisionomias de cerrado - foram encontradas 172 espécies de aves e 19 mamíferos (Martuscelli \& Olmos, 1993). Os pesquisadores responsáveis por este levantamento, deram destaque para o registro de algumas espécies, entre as quais: Sarcoramphus papa (urubu-rei); Leptodon cayannensis (gavião de cabeça cinza) - espécie com poucos registros para São Paulo; Oryzoborus angolensis (curió) - encontrado em locais brejosos, esta espécie está praticamente extinta devido à perseguição por criadores de aves; Callicebus personatus (guigó ou sauá) - macaco restrito ao leste brasileiro e considerado ameaçado de extinção; Chrysocyon brachyurus (lobo-guará) - segundo os pesquisadores, todos os registros desta espécie foram feitos nas divisas das unidades de conservação com reflorestamentos e canaviais, "um sintoma da necessidade do manejo do habitat tanto nas unidades como no entorno, visto que o lobo-guará procura seu alimento em áreas abertas, de vegetação baixa, utilizando o cerradão apenas para abrigo"; Felis concolor (onça-parda, sussuarana) - que devido à destruição e fragmentação de seu habitat, este predador está se tornando raro em todo o estado de São Paulo; Chrysolampis mosquitus (beija-flor-vermelho) - com apenas um único registro anterior no estado de São Paulo (em Anhembi Paulista); Nyctiblus grandis (mãe-da-lua-gigante) - ave noturna com poucos registros em toda a América do Sul.

Jorge et al. (2001) avaliaram a riqueza e abundância de pequenos mamíferos em ambientes de cerrado e floresta na gleba Pé-de-Gigante, bem como em cultura de Eucalyptus grandis vizinha à gleba Pé-de-Gigante, em um período de 12 meses. Em 126 capturas de indivíduos e um avistamento, totalizaram-se 13 gêneros e espécies, sendo 8 de roedores e 5 de marsupiais.

Em levantamento faunístico recente, Munari et al. (2001) verificaram a ocorrência e intensidade de uso por mamíferos de médio e grande porte em um eucaliptal próximo à gleba Pé-de-Gigante e registraram a presença de várias 
espécies, entre as quais, tamanduá mirim (Myrmecophaga tridactyla), tamanduá bandeira (Tamandua tetradactyla), cachorro do mato (Cerdocyon thous), loboguará (Cerdocyon brachyurus), quati (Nasua nasua), jaritataca (Conepatus chinga), irara (Eira barbara), onça parda (Puma concolor), jaguatirica (Felis pardalis), cutia (Dasyprocta azarae), veado campeiro (Ozotoceros bezoarcticus), entre outras.

\subsection{Diagnóstico Ambiental da Área de Estudo}

O diagnóstico ambiental das áreas do entorno do Parque teve como principal objetivo subsidiar as propostas de interligação das glebas e de proteção dos recursos naturais da área de estudo.

Para atender aos objetivos deste estudo, fez-se alterações no mapa de uso e cobertura das terras de Shida (2000), com a inserção de algumas classes de uso e cobertura, como a delimitação das várzeas e as atividades que utilizam fogo para colheita e manejo. Para a realização das alterações e inserções das classes de interesse, utilizou-se de análises das seguintes imagens de satélite: 1. inicialmente uma imagem Landstat 5 , sensor TM, Bandas 3, 4, e 5, órbita ponto 220-075, de data 24/08/1996, obtida junto ao INPE; 2. posteriormente, uma imagem Landstat 7, $\mathrm{ETM}^{+}$, Bandas 3, 4, e 5, órbita ponto 220-075, de data 12/05/2001, obtida junto ao INPE, e 3. duas cenas de imagem de satélite

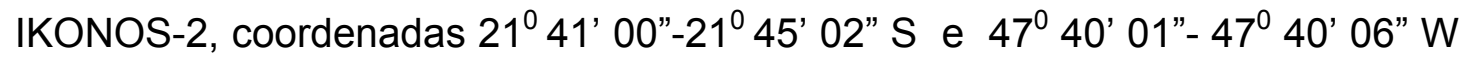
e coordenadas $21^{0} 41^{\prime} 06^{\prime \prime}-21^{0} 45^{\prime} 08^{\prime \prime}$ S e $47^{0} 33^{\prime} 55^{\prime \prime}$ e $47^{0} 34^{\prime} 01^{\prime \prime} \mathrm{W}$ ), de data $11 / 02 / 2002$.

Finalizadas as alterações no mapa original de Shida (2000), realizou-se o diagnóstico e conhecimento da área de estudo, por meio da análise de índices da paisagem, levantamentos em campo, diagnóstico das áreas de preservação permanente dos corpos d'água (utilizando a imagem de satélite Ikonos) e o 
mapeamento das áreas de maior risco potencial de erosão, que terão as metodologias descritas nos subitens a seguir.

\subsection{1 Îndices da Paisagem:}

Os índices da paisagem são instrumentos de análise importantes para subsidiar propostas para o aumento da conectividade de uma paisagem fragmentada. A análise dos índices de área, abundância, área nuclear, forma ou vizinhança, por exemplo, possibilita diagnosticar não apenas o grau de fragmentação da paisagem e o isolamento da vegetação nativa, mas prever alterações físicas e biológicas ao longo do tempo (McGarigal \& Marks, 1995).

Utilizando o programa FRAGSTATS (versão 3.01.02), foram selecionados os descritores da paisagem, para as classes de vegetação nativa - vegetação florestal de interflúvio, cerrado e vegetação ripária.

A escolha dos índices objetivou auxiliar no conhecimento da paisagem e subsidiar a escolha de áreas para a interligação das glebas e áreas prioritárias para serem recuperadas ou restauradas. Os critérios estabelecidos foram:

- quantificar a porcentagem de vegetação nativa existente na área de estudo e identificar as classes de vegetação nativa mais fragmentadas e isoladas na paisagem;

- analisar o tamanho e forma dos fragmentos e a influência dos efeitos de borda;

- verificar as classes de vegetação nativa que estão mais isoladas na paisagem.

Os índices analisados foram:

a) Número de Manchas ou Fragmentos (NM): é o número de manchas ou fragmentos de uma determinada classe na matriz. No presente estudo, foi feita análise das classes de vegetação florestal de interflúvio, cerrado e vegetação natural. Este índice é representado por: 
$\mathrm{NM}=\mathrm{ni}$

Onde, ni é número de manchas de uma determinada classe na paisagem.

b) Porcentagem de Vegetação Nativa na Paisagem (PVN): expressa o quanto a classe analisada representa a paisagem. Neste estudo, representa a porcentagem da vegetação nativa na paisagem.

$P V N=\frac{\sum_{j=1}^{n} a_{i j}}{100}$.

Onde, $\mathrm{i}=$ número de classes de fragmento (de 1 a $n$ ); $j$ = número de fragmentos (de 1 a $n$ ); $a_{i j}=$ área do fragmento i na classe $\mathrm{j} ; \mathrm{A}=$ área total da paisagem $\left(\mathrm{m}^{2}\right)$.

c) Tamanho Médio da Mancha (TMM): representa o tamanho médio das manchas de uma determinada classe. TMM > 0, sem limite. É obtido por:

$\mathrm{TMM}=\frac{\sum_{\mathrm{j}=1}^{\mathrm{n}} \text { aij }}{\mathrm{ni}} \times \frac{1}{10.000}$

onde, aij = área $\left(\mathrm{m}^{2}\right)$ da mancha (manchas da classe $\mathrm{i}$ ); $\mathrm{j}=$ número de manchas, de $1 \mathrm{a} \mathrm{n}$; $\mathrm{ni}=$ número de manchas de uma determinada classe na paisagem.

d) Desvio Padrão do Tamanho das Manchas (DPTM): é o desvio padrão do conjunto de manchas de uma mesma classe.

$D P T M=\sqrt{\frac{\sum_{j=1}^{n}\left[\text { aij- }\left[\frac{\sum_{j=1}^{n} \text { aij }}{n i}\right]^{2}\right.}{n i} \times \frac{1}{10.000}}$

onde, aij = área $\left(\mathrm{m}^{2}\right)$ da mancha (manchas da classe $\mathrm{i}$ ); $\mathrm{j}=$ número de manchas, de 1 a $\mathrm{n} ; \mathrm{Ni}=$ número de manchas de uma determinada classe na paisagem. 
e) Índice Médio de Forma: mensura a forma média dos fragmentos da(s) classe(s) de vegetação de interesse. Valores de índice médio de forma maiores que 1 significam que, em média, os fragmentos de vegetação nativa possuem formato irregular e alongado.

IMF $=\frac{\sum_{\mathrm{i}=1}^{\mathrm{n}}\left(\frac{0,25 \mathrm{p}_{i j}}{\sqrt{\mathrm{a}_{i j}}}\right)}{n i}$

Onde, $p_{i j}=$ perímetro do fragmento $\mathrm{ij} ; \mathrm{i}, \mathrm{j}, \mathrm{n}, \mathrm{a}_{\mathrm{ij}}$ e $\mathrm{ni}=$ já definidos anteriormente.

f) Porcentagem da Área Nuclear da Paisagem (\%AN ou \%CLAND): representa a porcentagem da paisagem compreendida pela área nuclear de cada classe. Entende-se como área nuclear a área do fragmento de vegetação nativa que não está sob influência dos efeitos negativos de borda.

Com base em informações obtidas na literatura, foi considerado, para o cálculo de áreas nucleares, um efeito de borda de 60 metros (Pivello et al., 1999; Rodrigues, 1998; Murcia, 1995).

$\% A N=\frac{\sum_{i=1}^{n} \text { aij } c}{A} \times 100$

onde, aij ${ }^{c}=$ área nuclear ou central $\left(\mathrm{m}^{2}\right)$ das manchas da classe $\mathrm{i}$, dentro de uma distância específica da mancha de uma determinada classe i; A = área total da paisagem.

g) Índice da Proximidade Média (IPM): relaciona cada mancha àquelas mais próximas que pertençam a uma classe, em um raio pré-determinado de $1 \mathrm{Km}$. IPM $\geq 0$, sem limite. IPM=0 se todas as manchas de determinada classe não possuem vizinhos mais próximos dentro do raio pré-estabelecido de $1 \mathrm{~km}$. IPM aumenta com a diminuição do isolamento e da fragmentação das manchas da mesma classe. 
$I P M=\frac{\sum_{j=1 s=1}^{n} \sum_{s i j}^{n} \frac{\text { aijs }}{h i}}{n i}$

onde, hij = distância $(\mathrm{m})$ da mancha de uma determinada classe à mancha vizinha mais próxima; $\mathrm{j}$ = número de manchas, de 1 a $\mathrm{n}$; aijs = área $(\mathrm{m} 2)$ das manchas de uma determinada classe i dentro da distância determinada $(1 \mathrm{~km})$ de uma mancha; ni = número de manchas de uma determinada classe na paisagem.

3.2.2. Diagnóstico de campo dos problemas ambientais decorrentes do uso das terras

Dois levantamentos de campo foram realizados na área de estudo para registrar as irregularidades ambientais decorrentes do não-cumprimento da legislação ambiental, sendo o primeiro, realizado em setembro de 2001 e, o segundo, em outubro de 2002.

Foram amostrados pontos aleatórios, utilizando um receptor de GPS (Global Positioning System - Garmin GPSMA 76), a Carta do Brasil - Folha Luiz Antônio, escala 1:50.000 (IBGE, 1971) e o mapa de uso das terras elaborado por Shida (2000, modificado).

Em etapa anterior, as principais leis ambientais utilizadas para avaliar o uso do solo foram analisadas, dentre as quais:

- Lei no 4.771, de 15 de setembro de 1965 (institui o Código Florestal; já com alterações da Lei $n^{0} 7.803$, de 18 de julho de 1989).

"Art. $2^{\circ}$ - Consideram-se de preservação permanente, ..., as florestas e demais formas de vegetação natural situadas:

- ao longo dos rios ou de qualquer curso d'água desde o seu nível mais alto em faixa marginal cuja largura mínima seja ${ }^{1}$ :

\footnotetext{
${ }^{1}$ Alínea com redação determinada pela Lei nº 7.803, de 18 de julho de 1989.
} 
1) de 30 (trinta) metros para os cursos d'água de menos de 10 (dez) metros de largura;

2) de 100 (cem) metros para os cursos d'água que tenham de 50 (cinqüenta) a 200 (duzentos) metros de largura;

3) ao redor das lagoas, lagos ou reservatórios d'água naturais ou artificiais;

4) nas nascentes, ainda que intermitentes e nos chamados "olhos d'água", qualquer que seja a sua situação topográfica, num raio mínimo de cinqüenta metros de largura ${ }^{2}$;

Artigo $3^{\circ}$ - Consideram-se, ainda, de preservação permanente, ..., as florestas e demais formas de vegetação natural destinadas: a) a atenuar a erosão das terras;

- Medida Provisória n 2.166-65, de 28 de Junho de 2001.

Art. $1^{\circ}$ Os arts. 1ำ 4ํㅜ 14,16 e 44, da Lei no 4.771 , de 15 de setembro de 1965, passam a vigorar com as seguintes redações:

Artigo $1^{\circ}$ - As florestas existentes no território nacional e as demais formas de vegetação, reconhecidas de utilidade às terras que revestem, são bens de interesse comum a todos os habitantes do País, .....

$\S 2^{\circ}$ Para os efeitos deste Código, entende-se por:

II - Área de preservação permanente: área protegida nos termos dos arts. $2^{\circ} \mathrm{e}$ $3^{\circ}$ desta Lei, coberta ou não por vegetação nativa, com a função ambiental de preservar os recursos hídricos, a paisagem, a estabilidade geológica, a biodiversidade, o fluxo gênico de fauna e flora, proteger o solo ...

V - Interesse social: a) as atividades imprescindíveis à proteção da integridade da vegetação nativa, tais como: prevenção, combate e controle do fogo, controle da erosão, erradicação de invasoras e proteção de plantios com espécies nativas, ...;

\footnotetext{
${ }^{2}$ Alínea com redação determinada pela Lei nº 7.803, de 18 de julho de 1989.
} 
- Resolução CONAMA 303, de 2002.

Art. $1^{\circ}$ Constitui Área de Preservação Permanente a área situada: ao redor de lagos e lagoas naturais (50 metros);

- Lei n 9.605, de 12 de fevereiro de 1998 (dispõe sobre as sanções penais e administrativas derivadas de condutas e atividades lesivas ao meio ambiente...). - "Seção II - Dos Crimes contra a Flora".

Art. 38. Destruir ou danificar floresta considerada de preservação permanente, mesmo que em formação, ou utilizá-la com infringência das normas de proteção:

Art. 39. Cortar árvores em floresta considerada de preservação permanente, ... Art.40. Causar dano direto ou indireto às Unidades de Conservação...."

Art.41 - Provocar incêndio em mata ou floresta

Art.48 - Impedir ou dificultar a regeneração natural de florestas ...

Art.52 - Penetrar em Unidades de Conservação conduzindo substâncias ou instrumentos próprios para a caça..., sem licença da autoridade competente.

Art.53 - Dos crimes previstos nesta Seção, a pena é aumentada de um sexto a um terço se: I. do fato resultar diminuição de águas naturais, a erosão do solo,

- Lei Federal 9985, de 18 de julho de 2000 - Regulamenta o art.225, § $1^{0}$, incisos I, II, III e VIII da Constituição Federal, institui o Sistema Nacional de Unidades de Conservação da Natureza e dá outras providências. Cap. I - das Disposições preliminares:

Art. $2^{0}$ Para os fins previstos nesta Lei, entende-se por:

XVIII - zona de amortecimento: o entorno de uma unidade de conservação, onde as atividades humanas estão sujeitas as normas e restrições específicas, com o propósito de minimizar os impactos negativos sobre a unidade;

XIX - corredores ecológicos: porções de ecossistemas naturais ou seminaturais, ligando unidades de conservação, que possibilitam entre elas o fluxo de genes 
e o movimento da biota, facilitando a disposição de espécies e a recolonização de áreas degradadas, bem como a manutenção de populações que demandam para sua sobrevivência áreas com extensão maior do que aquela das unidades individuais.

Cap.IV - da Criação, Implantação e Gestão das Unidades de Conservação Art. 25 - As unidades de conservação, ...., devem possuir uma zona de amortecimento e, quando conveniente, corredores ecológicos.

$\S 1^{0} \mathrm{O}$ órgão responsável pela administração da unidade estabelecerá normas específicas regulamentando a ocupação e o uso dos recursos da zona de amortecimento e dos corredores ecológicos de uma unidade de conservação.

$\S$ Os limites da zona de amortecimento e dos corredores ecológicos e as respectivas normas de que dispõe o $\S 1^{0}$ poderão ser definidos no ato da criação da unidade ou posteriormente.

Art.27 - As unidades de conservação devem dispor de um Plano de Manejo

$\S 1^{0} \mathrm{O}$ Plano de Manejo deve abranger a área da unidade de conservação, sua zona de amortecimento e os corredores ecológicos, incluindo medidas com o fim de promover sua integração à vida econômica e social das comunidades vizinhas.

- Lei Estadual 10.547/00 - "Capítulo I - Da Proibição do Emprego do Fogo".

Artigo $1^{\circ}$ - É vedado o emprego do fogo:

I - nas florestas e demais formas de vegetação;

III - numa faixa de:

d) cinqüenta metros a partir do aceiro, que deve ser preparado, mantido limpo e não cultivado, de dez metros de largura ao redor das Unidades de Conservação;

e) quinze metros de cada lado de rodovias estaduais e federais e de ferrovias medidos a partir da faixa de domínio". 
- Portaria do IBAMA 94/98-N, de 09 de julho de 1998 e Decreto Estadual 45.869, de 22 de junho de 2001 - estabelece medidas iguais as da Lei Estadual acima citada.

Em campo, realizou-se amostragem aleatória das áreas de preservação permanente (APPs) dos córregos Rico e Paulicéia (e seus afluentes), parte da microbacia do córrego Bebedouro e a margem direita do rio Mogi-Guaçu.

Nos pontos amostrados, verificou-se não apenas a adequação do local frente à legislação ambiental, mas também o grau de conservação da área, caracterizando o estado da vegetação, sinais de incêndio e indícios de ocorrência de caça de animais silvestres (presença de cevas e armadilhas).

Foram diagnosticadas, também, as áreas com ocorrência de erosão. Os critérios estabelecidos para este levantamento foram: presença de sinais evidentes de erosão acentuada, como ocorrência de voçoroca, sulcos e solos expostos em áreas de pastagem e o assoreamento dos corpos d'água superficiais. Neste estudo, considerou-se assoreamento o processo de arraste de solo, decorrente, principalmente, das águas da chuva, promovendo o acúmulo e enchimento dos leitos dos corpos d'água.

Práticas ou atividades que contribuem ou são responsáveis pela degradação dos recursos naturais da área de estudo também foram registrados, como: o uso de fogo na colheita da cana-de-açúcar e no "manejo" do pasto, presença de lixo e restos de culturas nas bordas das glebas do PEV, ausência de aceiros ou de zonas de proteção ao redor das glebas, caça de animais silvestres, problemas ambientais decorrentes da implantação do sistema viário e outras atividades. 
3.2.3 Análise das Áreas de Preservação Permanente dos corpos d'água.

Mediante o uso de duas cenas de imagem de satélite IKONOS-2, com resolução de $1 \mathrm{~m}$, foi possível quantificar o uso e cobertura das áreas de preservação permanente (APPs) dos corpos d'água (100 m da margem direita do rio Mogi-Guaçu, a partir do leito maior sazonal, faixas de $30 \mathrm{~m}$ de cada lado dos demais cursos d'água e $50 \mathrm{~m}$ ao redor de represas e lagos).

A hidrografia da área foi digitalizada sobre esta imagem de satélite, utilizando o programa Arc View - versão 8.1 (ESRI, 2001). Aferições e correções da hidrografia foram feitas por meio de verificações em campo e confrontando com a hidrografia da Carta do Brasil - Folha Luiz Antônio, esc.1:50.000 (IBGE, 1971), também em formato digital.

Os buffers (tampões) correspondentes às larguras das APPs, definidas no Código Florestal (Lei 4771/65), foram gerados a partir da hidrografia, utilizando o programa Arc GIS - Arc Map versão 8.1 (ESRI, 2002). Estes buffers foram sobrepostos à imagem de satélite e feita a classificação do uso e cobertura das terras.

Realizou-se classificação visual, definindo-se três classes:

1. vegetação ripária preservada: estão inseridas nesta classe as áreas com vegetação ripária nativa que não sofreram interferência antrópica.

2. vegetação ripária alterada: áreas que, provavelmente, sofreram interferência antrópica (cultivo agrícola, fogo, corte seletivo de árvores, desmatamentos, pastoreio) e foram abandonadas. Nestas áreas há predomínio de espécies invasoras, principalmente de gramíneas exóticas e restos de cultura, como a cana de açúcar.

3. agropecuária: áreas com ocupação irregular e que estão sendo cultivadas (cana-de-açúcar e outras culturas) ou utilizadas para pastoreio intensivo (com práticas de roçadas). Nas várzeas próximas, verifica-se a presença de drenos. 
A acurácia e a qualidade desta classificação foi avaliada com base na matriz de erros (ou de confusão), por meio de pontos de controle obtidos em campo (verdade terrestre), com o auxílio de um receptor GPS e pelo índice de concordância de Kappa. Após verificar a acurácia na matriz de erros, calculouse a acurácia temática, utilizando o coeficiente Kappa (Rosenfield \& FitzpatrickLins, 1986), que determina a concordância esperada através da fórmula:

$$
K=\frac{P_{0}-P_{c}}{1-P_{c}}
$$

onde:

$$
\begin{aligned}
& P_{0}=\sum_{i-1}^{m} X_{i i}=\text { concordância observada. } \\
& P_{c}=\sum_{i-1}^{m} X_{i}+X_{+i}=\text { concordância esperada }
\end{aligned}
$$

$\mathrm{m}=$ número de linhas na matriz de erros; $X_{\mathrm{ii}}=$ número de combinações ao longo da diagonal; $\mathrm{X}_{i_{+}}=$total de observações na linha $i ; X_{+i}=$ total de observações na coluna $i$.

O coeficiente Kappa pode apresentar valores entre -1 e +1. A interpretação dos coeficientes de concordância possui a seguinte classificação: $<0=$ péssimo; $0<\mathrm{K}<0,2=$ ruim; $0,4<\mathrm{K}<0,4=$ razoável; $0,4<\mathrm{K}<0,6=$ bom; $0,6<$ $\mathrm{K}<0,8=$ muito bom; $0,8<\mathrm{K}<1,0=$ excelente.

Concluída a avaliação da acurácia e da qualidade da classificação, quantificou-se as APPs que estão regulares frente à legislação ambiental e as que estão sendo irregularmente ocupadas ou que foram abandonadas, mas não foram recuperadas. 
3.2.4 Mapeamento das áreas de risco de erosão no entorno das glebas do Parque Estadual de Vassununga

Por meio de técnicas de geoprocessamento, o método para gerar o mapa das áreas de risco potencial de erosão teve como base a Equação Universal de Perda de Solos (EUPS ou USLE - Universal Soil Loss Equation) e a manipulação de dados, entre os quais erosividade, erodibilidade, comprimento do declive, declividade, uso e cobertura do solo e práticas conservacionistas (Cerri, 1999).

A EUPS é uma equação empírica, utilizada para computar erosão laminar e linear, em função de fatores que representam o clima, o solo, a topografia e o uso e cobertura do solo. A equação original evoluiu, após anos, para o modelo revisado por Wischmeier \& Smith (1978) (Equação 11):

$A=$ R.K.L.S.C.P

Onde:

$\mathrm{A}=$ perda média anual de solo por unidade de área ( $\left.\mathrm{mg} \cdot \mathrm{ha}^{-1} \mathrm{ano}\right)$;

$\mathrm{R}=$ erosividade das chuvas $\left(\mathrm{mJ} \mathrm{ha} \mathrm{H}^{-1} \mathrm{~mm} . \mathrm{h}^{-1}\right)$;

$\mathrm{K}=$ erodibilidade do solo $\left(\mathrm{mg} \mathrm{ha}^{-1}\left(\mathrm{~mJ} \mathrm{ha}^{-1} \mathrm{~mm} \mathrm{~h}^{-1}\right)^{-1}\right)$. ano ${ }^{-1}$;

$\mathrm{L}$ e $\mathrm{S}$ = fatores comprimento da encosta (dimensional) e declive (adimensional);

$C=$ fator uso e manejo (adimensional);

$\mathrm{P}=$ fator práticas conservacionistas (adimensional).

- Os fatores da EUPS utilizados neste estudo foram:

a) Erosividade (R):

Este índice numérico representa a capacidade da chuva em causar erosão em uma área sem proteção. As perdas de solo pelas chuvas são diretamente 
proporcionais ao valor de um parâmetro da precipitação: o "índice de erosão (EI)". O El é definido como o produto da energia cinética da chuva (E) pela sua intensidade máxima em 30 minutos $\left(I_{30}\right)$. A soma dos valores de $\mathrm{El}$ de cada evento de chuva, isoladamente, em determinado período, representa a erosividade da chuva dentro daquele período. $\mathrm{O}$ valor $\mathrm{R}$ da equação é a média dos valores anuais de El de um período longo de tempo (Bertoni \& Lombardi Neto, 1990; Wischmeier \& Smith, 1978; Ranieri, 2000). Cerri (1999) utilizou a Equação 12 para a obtenção do índice de erosão:

$E I=68,730\left(r^{2} / P\right)^{0,841}$

Sendo:

$\mathrm{El}=$ média mensal do índice de erosão em $\mathrm{mJ} \mathrm{mm} \mathrm{ha}^{-1} \mathrm{~h}^{-1}$; $r$ = precipitação média mensal em milímetros;

$\mathrm{P}=$ precipitação média anual em milímetros.

Os dados de precipitação $(\mathrm{mm})$ de um período de 29 anos (1971 a 1999), referente à estação C4-095 - Usina Santa Rita (Bacia Turvo, Santa Rita do Passa Quatro, SP) foram obtidos no Banco de Dados Pluviométricos do Estado de São Paulo - Departamento de Águas, Esgoto e Energia Elétrica (DAEE, 2001). Utilizou-se apenas uma estação pluviométrica, devido ao fato da área de estudo estar totalmente inserida nesta estação. A erosividade calculada foi:

$\mathrm{R}$ (ou El) 29 anos $=826,2 \mathrm{~mJ} \mathrm{~mm} \mathrm{ha}{ }^{-1} \mathrm{~h}^{-1}$ 
b) Erodibilidade $(\mathrm{K})$ :

A erodibilidade é um fator inerente ao solo. Alguns tipos de solo são mais facilmente erodidos do que outros, mesmo que o declive, a precipitação, a cobertura vegetal e as práticas de conservação sejam as mesmas (Wischmeier et al., 1971; Ranieri, 2000). A erodibilidade tende a aumentar com o aumento do teor de silte.

No presente estudo, adotou-se os valores de erodibilidade $(K)$ utilizados por Cerri (1999). O autor utilizou o modelo matemático aplicado para os solos existentes na bacia do rio Piracicaba, desenvolvido por Denardin (1990) e adaptado por Levy (1995). O fato dos solos de ocorrência na área de estudo serem semelhantes aos existentes na bacia do rio Piracicaba, permitiu que o mapa de solos (Shida, 2000; Figura 3), fosse reclassificado com os valores de erodibilidade da Tabela 1, resultando no mapa de erodibilidade dos solos. As classes pedológicas deste Mapa, conforme a nova classificação da EMBRAPA (1999), são as seguintes:

- solos mais argilosos, que abrangem o Latossolo Vermelho distroférrico, textura argilosa ou muito argilosa, pertencente à Unidade Barão Geraldo; e o Latossolo Vermelho, álico textura média, pertencentes às Unidades Dois Córregos e Hortolândia;

- solos mais arenosos, abrangendo o Latossolo Vermelho-Amarelo, álico, textura média da Unidade Coqueiro; e Neossolo Quartzarênico, álico e excessivamente drenados;

- Neossolo, eutrófico, textura argilosa, substrato basalto ou diabásico;

- Gleissolo ou Neossolo Quartzarênico hidromórfico. 


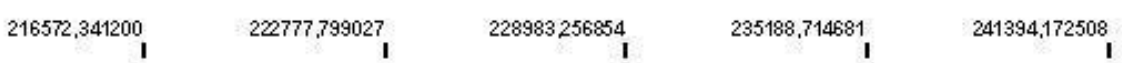

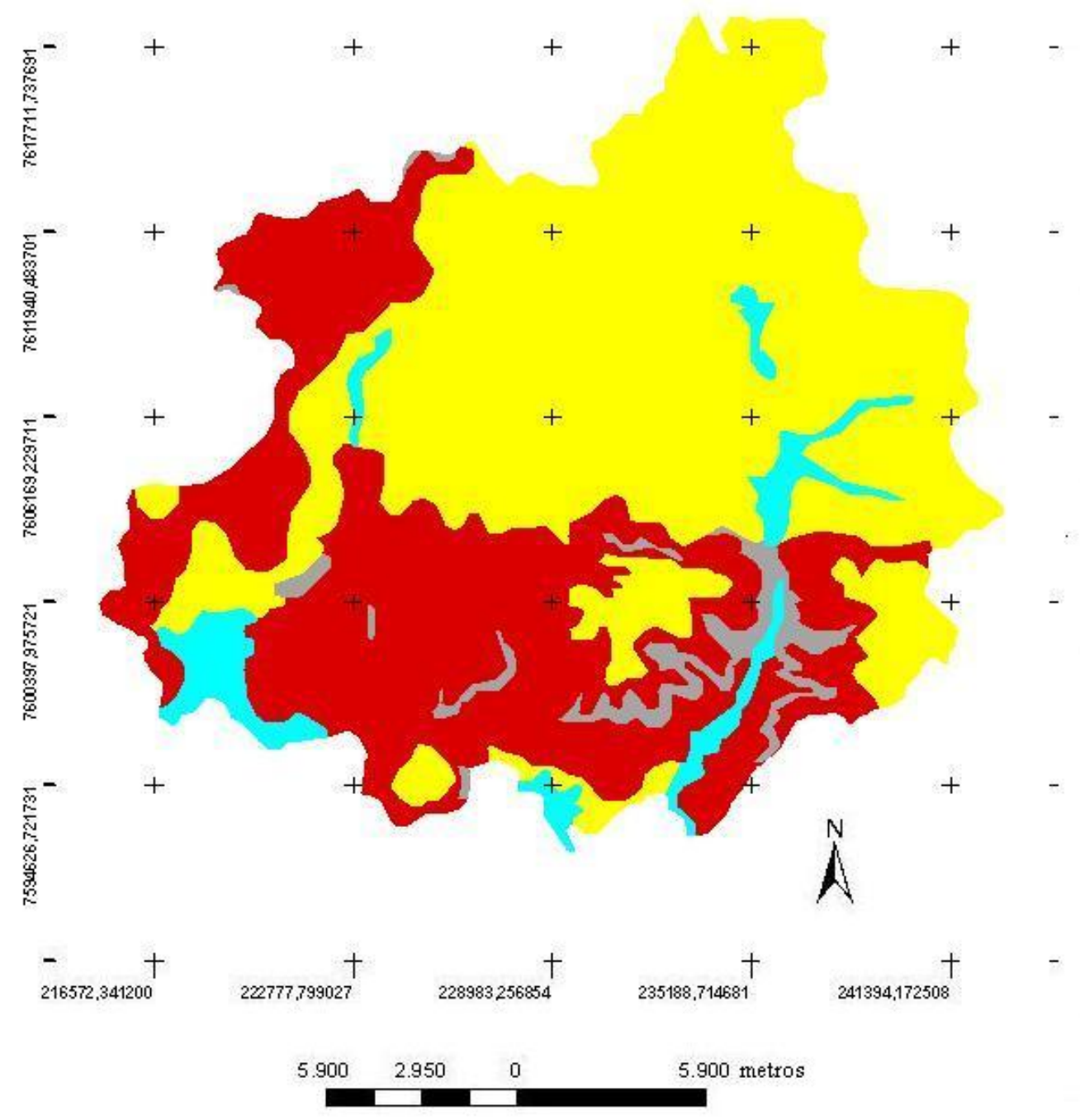

Latossolo Vermelho distroférrico / Latossolo Vermelho

Neossolo Quartzarênico / Latossolo Vermelho-Amarelo

Neossolo

Gleissolo ou Neossolo Quartzarênico hidromórfico

Figura 3 - Mapa de Solos (Shida, 2000) com a delimitação da região de estudo. 
Tabela 1. Valores de erodibilidade relativos aos solos da área de estudo, extraídos de Cerri (1999).

\begin{tabular}{lc}
\hline \multicolumn{1}{c}{ Unidades de Solo } & Fator K \\
\hline Latossolo Vermelho distroférrico / Latossolo Vermelho & 0.0156 \\
Neossolo Quartzarênico / Latossolo Vermelho-Amarelo & 0.0163 \\
Neossolo & 0.0411 \\
Gleissolo ou Neossolo Quartzarênico hidromórfico & 0.0681 \\
\hline
\end{tabular}

c) Fator topográfico (LS)

O fator LS é obtido através da multiplicação do comprimento do declive (fator L) pela declividade (fator S). Estes parâmetros foram obtidos utilizando a metodologia descrita por Hickey et al. (1994) e modificada por Cerri (1999). A fórmula em que o fator topográfico LS é calculado a partir do Modelo Digital de Elevação do Terreno (MDET), utilizando o programa ARC INFO GRID (Cerri et al., 2002), é expressa pela equação 14:

Fator LS $=(\lambda / 22,3)^{t}\left(65,41 \operatorname{sen}^{2} \beta+4,56 \operatorname{sen} \beta+0,065\right)$

Onde,

$\mathrm{T}=0,5$ se declive $\beta>3^{0} ; \mathrm{t}=0,4$ se declive $1,7^{0}<\beta<3^{0} ; \mathrm{t}=0,3$ se declive $0,6^{0}$.

Sendo:

$\lambda=$ comprimento de declive acumulado;

$\beta=$ ângulo da declividade morro abaixo;

$\mathrm{t}=$ inclinação da variável contingencial. 
O MDET foi gerado a partir da interpolação das curvas de nível, eqüidistantes 20 metros, extraídas do mapa topográfico do Instituto Brasileiro de Geografia e Estatística, folha Luiz Antônio (IBGE, 1971), escala de 1:50.000, por meio da rede de triangulação irregular.

O fator topográfico é adimensional e, neste estudo, os valores obtidos foram reclassificados em quatro grupos, seguindo a metodologia utilizada por Cerri (1999).

d) Fator Cultural ou Fator Uso-Manejo do Solo (C):

Este fator é a relação esperada entre as perdas de solo de um terreno cultivado em dadas condições e as perdas correspondentes de um terreno mantido continuamente descoberto. A redução das perdas de solo, se a área estiver cultivada, depende de combinações, como: tipo da cobertura vegetal, seqüência de culturas e práticas de manejo e o estádio de crescimento e desenvolvimento da cultura durante o período das chuvas (Bertoni \& Lombardi Neto, 1985).

Após a análise dos padrões de uso e ocupação do solo, foram estabelecidos os valores de C (Tabela 2), seguindo Bertoni \& Lombardi Neto (1990) e Castro (1992). 
Tabela 2. Valores do fator cultural, segundo Bertoni \& Lombardi Neto (1990) e Castro (1992)

\begin{tabular}{lc}
\hline \multicolumn{1}{c}{ Uso e Cobertura das Terras } & Fator C \\
\hline Cana-de-açúcar & 0.1124 \\
Silvicultura & 0.0470 \\
Vegetação florestal de interflúvio & 0.0004 \\
Pastagem/gramíneas/campo sujo & 0.0100 \\
Cerrado & 0.0004 \\
Vegetação ripária & 0.0004 \\
Corpos d'água & 0.0000 \\
Várzeas & 0.0100 \\
Edificações/urbanização & 0.0300 \\
Área de expansão urbana & 0.0300 \\
Cítricos & 0.1350 \\
\hline
\end{tabular}

e) Práticas Conservacionistas $(P)$

É a relação entre a intensidade de perdas de solo com determinada prática conservacionista e àquelas quando a cultura está plantada no sentido do declive (morro abaixo). Este fator representa o efeito das práticas conservacionistas, tais como plantio em nível, terraceamento e plantio em faixas (Cerri, 1999; Ranieri, 2000), conforme a Tabela 3. O valor de P adotado foi 0.5 , observando-se que em toda a área de estudo o plantio das culturas é em contorno. 
Tabela 3. Fator $\mathrm{P}$ das diferentes práticas conservacionistas, conforme Bertoni \& Lombardi Neto (1990).

\begin{tabular}{lc}
\hline \multicolumn{1}{c}{ Práticas conservacionistas } & Valor de P \\
\hline Plantio morro abaixo & 1,0 \\
Plantio em contorno & 0,5 \\
Alternância de capinas + plantio em contorno & 0,4 \\
Cordões de vegetação permanente & 0,2 \\
\hline
\end{tabular}

No programa ARCVIEW GIS versão 3.1 (ESRI, 1998), utilizando recursos do Map Calculator, todos os mapas e valores acima descritos foram multiplicados, obtendo-se o Mapa de Perda de Solo por Erosão. Este mapa expressa a perda de solo em toneladas por ano e por hectare.

Por sua vez, este mapa foi reclassificado em três categorias de riscos de erosão, tendo como parâmetro considerações de alguns autores sobre limites de tolerância de perda de solo (Bertoni \& Lombardi Neto, 1985; Cerri, 1999; INPE, 2002). As categorias de risco de ocorrência de erosão adotadas foram: baixo $=0-2$ t.ha $^{-1} ;$ médio $=2-4 \mathrm{t} \cdot \mathrm{ha}^{-1}$; alto $=>4 \mathrm{t} \cdot \mathrm{ha}^{-1}$.

O conceito sobre limites de tolerância de perda de solo foi introduzido por Wischmeier \& Smith (1978) e considera a quantidade de terra que pode ser perdida por erosão (em t.ha ${ }^{-1}$.ano ${ }^{-1}$ ) mantendo o solo com níveis elevados de produtividade agrícola, por um longo período de tempo (Bertoni \& Lombardi Neto, 1985). É importante destacar, portanto, a falta de pesquisas que determinem níveis aceitáveis de perda de solo sob uma perspectiva ambiental, considerando a preservação dos recursos naturais, principalmente a preservação dos mananciais e corpos d'água, quanto aos aspectos de assoreamento e contaminação. Lal (1998) considera apropriado ampliar os parâmetros desta análise, com o objetivo de determinar a maior taxa de erosão 
de solo permitida, sem ameaçar a produtividade dos solos, mas também, sem contaminar os recursos hídricos e sem comprometer a qualidade do ar. Para o autor, parâmetros ambientais devem ser incorporados no conceito de tolerância de perda de solo e novas pesquisas devem concentrar-se nesta questão.

A verificação do mapa de risco de erosão foi feita por meio de observações em campo, em locais onde já ocorre erosão acentuada, como grandes voçorocas, ravinas, "falhas" em áreas de pastagem (erosão em sulco, com solo exposto) e mananciais assoreados, sendo utilizado um receptor GPS para o registro das coordenadas.

Os dados observados em campo foram espacializados, gerando um novo plano de informação, que foi sobreposto ao mapa de risco de erosão, permitindo verificar se os locais de erosão existentes coincidiam com as áreas que apresentavam riscos altos de erosão. 


\subsection{Propostas de Interligação das glebas do Parque Estadual de Vassununga}

Após a finalização do diagnóstico e caracterização ambiental da área de estudo, foram desenvolvidas propostas de interligação das glebas, em duas etapas:

3.3.1 Primeira Etapa: Interligação das glebas do PEV por meio da aplicação da legislação ambiental estadual e federal.

Foram gerados planos de informações das áreas de preservação permanente previstas no Código Florestal, bem como as áreas com restrição de uso previstas na legislação ambiental, por meio do programa ArcView versões 3.1 e 8.1 (ESRI, 1998; 2002, respectivamente). Estes planos de informação foram posteriormente sobrepostos ao mapa de uso das terras (modificado de Shida, 2000), para gerar o mapa final da Primeira Etapa: "mapa de interligação das glebas do PEV, com base na legislação ambiental".

As leis, decretos e normas utilizados para gerar os planos de informação foram:

- Lei 4771/65: foram criadas zonas tampão de 30 metros para os cursos d'água de até 10 metros de largura; de 100 metros para o rio Mogi-Guaçu; de 50 metros ao redor de lagos e represas. As áreas de preservação permanente dos mananciais foram delimitadas a partir do leito maior sazonal, ou seja, o limite de inundação que o curso d'água atinge todos os anos e não nas cheias excepcionais. Ao redor de represas, nascentes e lagos, as zonas tampão foram de 50 metros, conforme a Resolução CONAMA 303/02, publicada no Diário Oficial da União, em 13/05/2002. 
- Lei 9985/2000 - Sistema Nacional de Unidades de Conservação (SNUC): esta Lei prevê em seu Artigo 25 que as unidades de conservação, exceto Área de Proteção Ambiental e Reserva Particular do Patrimônio Natural, devem possuir uma zona de amortecimento e, quando conveniente, corredores ecológicos; porém não definindo larguras específicas e quais atividades antrópicas podem ser exercidas nestas áreas. No Artigo 27 , está determinado que as unidades de conservação devem dispor de um Plano de Manejo, devendo este abranger sua zona de amortecimento e os corredores ecológicos.

- Resolução CONAMA $n^{0}$ 13/90, anterior ao SNUC, define que "o Órgão responsável por cada Unidade de Conservação, juntamente com os órgãos licenciadores e de meio ambiente, definirá as atividades que possam afetar a biota da Unidade de Conservação..." "num raio de dez quilômetros".

- Portaria IBAMA 94-N/1998; Lei Estadual 10.547/2000; Decreto Estadual 45869/2001: estabelecem a proibição de queimadas numa faixa de 50 metros ao redor das unidades de conservação e de 15 metros em cada lado das rodovias, tanto estaduais como federais.

Os buffers gerados no Programa Arc View 3.1 e 8.1 (ESRI, 1998; 2002) buffers das APPs foram integrados para gerar o mapa final da Primeira Etapa, ou seja, a representação temática do cumprimento da legislação ambiental, principalmente, o artigo $2^{0}$ do Código Florestal (Lei 4771/65). 
3.3.2 Segunda Etapa: Proposta de interligação e conservação das glebas do PEV por meio do manejo dos elementos estruturais da paisagem.

Esta etapa contempla a escolha de áreas visando ao aumento da conectividade da paisagem, por meio da recuperação e restauração de áreas degradadas para a implantação de corredores e pontos de ligação e propostas de manejo para as glebas do PEV.

Para gerar os corredores, pontos de ligação e passagens para a fauna silvestre, utilizou-se os resultados obtidos no diagnóstico de campo e na caracterização da área de estudo.

Os parâmetros utilizados para a escolha de áreas prioritárias dos corredores e pontos de ligação foram:

a) Aumento da porcentagem de habitat (porcentagem de vegetação nativa) na área de estudo, recuperando ou restaurando a vegetação nativa nas áreas dos corredores e implantando "ilhas de biodiversidade" em meio às áreas cultivadas. Neste estudo, considera-se como ilhas de biodiversidade as porções de vegetação nativa, implantadas entre talhões de eucalipto e servindo, principalmente, de pontos de ligação para a avifauna;

b) incorporação das áreas de maior risco de erosão, também visando a restauração destas áreas, principalmente às localizadas no entorno próximo às glebas ou próximas dos mananciais e corpos d'água;

c) áreas onde a vegetação nativa foi suprimida e atualmente encontram-se abandonadas, estando em processo de regeneração natural;

d) proximidade de fragmentos de vegetação nativa. A escolha de rotas de corredores, procurando interligar fragmentos remanescentes de vegetação nativa, considerou três aspectos: o aumento da área efetiva dos fragmentos, promover áreas de refúgio e de locomoção mais seguras para determinadas espécies da fauna, principalmente espécies generalistas e/ou que necessitam de amplas áreas de vida para sobreviver; 
e) informações encontradas relativas à fauna silvestre, principalmente o hábito de locomoção e forrageamento de determinadas espécies;

f) distância de estradas, edificações e áreas de expansão urbana - as áreas com edificações, como sede de propriedades agrícolas e de usinas, e a proximidade com áreas de expansão urbana, foram consideradas áreas inaptas para a implantação de corredores e pontos de ligação;

g) custo de implantação: uma breve análise de custo considerou apenas o custo do reflorestamento com espécies arbóreas nativas, não levando em conta o valor da terra para fins de desapropriação ou o valor de benfeitorias existentes na área. A análise de custo serviu para subsidiar a tomada de decisão entre áreas com benefícios ambientais semelhantes; neste caso, áreas com menor custo de implantação foram prioritárias.

Também foram avaliados aspectos socio-econômicos, relativos às áreas que estejam sendo utilizadas de forma compatível com a conservação dos recursos naturais, como, por exemplo, áreas com práticas adequadas de conservação do solo, com a construção de terraços bem dimensionados, a manutenção de aceiros entre as áreas agrícolas e os fragmentos de vegetação nativa e outras medidas conservacionistas, evitando-se estes locais na escolha das rotas dos corredores.

Com exceção do item "análise preliminar de custo", os parâmetros acima descritos foram transformados em planos de informação (mapas temáticos) e integrados no programa Arc View versão 8.1 (ESRI, 2001), para gerar o mapa preliminar da segunda etapa.

As propostas para a implantação de dispositivos de proteção da fauna silvestre, como túneis, pontes e grades de proteção consideraram as áreas de maior ocorrência de atropelamentos da fauna silvestre.

Além da interligação das glebas do PEV, foram feitas propostas relacionadas ao aumento de suas áreas e à proteção dos efeitos de borda (como a implantação de faixas de amortecimento ou zonas tampão). A 
metodologia para gerar as faixas de amortecimento foi a mesma utilizada para gerar as APPs dos corpos d'água - geração de "buffers" utilizando o programa Arc View versão 8.1 (Esri, 2001). Para o aumento do tamanho das glebas, também foram considerados parâmetros de restauração de áreas degradadas, incorporação de áreas de risco potencial de erosão contíguas às glebas, proximidade de outros fragmentos de fisionomias de vegetação semelhantes, proteção dos recursos hídricos superficiais e a ausência de estradas e edificações.

A sobreposição dos planos de informação, entre os quais o mapa topográfico (Shida, 2000), a imagem de satélite Ikonos, o mapa de uso e cobertura das terras (Shida, 2000, modificado), o mapa preliminar dos corredores e pontos de ligação e o mapa de erosão potencial foram sobrepostos e analisados de forma integrada, permitindo a digitalização das áreas a serem incorporadas às glebas do PEV. Por fim, essas áreas foram incorporadas ao mapa preliminar - mapa dos corredores e pontos de ligação, para gerar o mapa final da etapa 2, ou seja, o mapa indicativo das áreas de interligação das glebas por corredores e pontos de ligação, dos locais de implantação de túneis e pontes para a fauna silvestre e as áreas a serem incorporadas ao PEV, para o aumento efetivo do tamanho de suas glebas.

\subsection{Propostas para a matriz}

Indicou-se propostas de alteração do uso das terras com o objetivo de cessar ou alterar as atividades que, direta ou indiretamente, têm promovido a degradação do Parque Estadual de Vassununga, diagnosticadas em campo e por meio de análise de imagens de satélite.

A influência dos tipos de atividades humanas do entorno (matriz) sobre a integridade ecológica das áreas destinadas à conservação e o grau de 
heterogeneidade dos tipos de habitat, podem influenciar significativamente no fluxo de nutrientes e sedimentos, bem como na persistência de espécies de plantas e animais. Uma unidade de conservação pode sofrer influências positivas ou negativas de seu entorno (Collinge, 1996; Pires, 1999; R.R. Rodrigues, com. pessoal).

A paisagem em que o Parque Estadual de Vassununga está inserida é um exemplo de como a baixa permeabilidade da paisagem, ou seja, o desmatamento desordenado (principalmente nas décadas de 70 e 80), a construção de rodovias (incluindo a Rodovia Anhangüera, que cortou ao meio uma das glebas do PEV - dando origem as Glebas Capetinga Leste e Oeste), o uso de fogo na colheita da cana-de-açúcar (muitas vezes, fogo simultâneo nas quatro faces do talhão, causando a morte de muitos animais silvestres), além da caça e outros fatores, são exemplos da baixa permeabilidade dessa matriz. 


\section{RESULTADOS E DISCUSSÃO}

\subsection{Diagnóstico Ambiental da Área de Estudo}

A reclassificação do mapa de uso e cobertura das terras de Shida (2000) resultou em alterações nas classes 1, 2, 6, e a inserção de duas novas classes. As principais alterações nas classes de uso e cobertura estão descritas na Tabela 4.

Tabela 4. Alterações nas classes de uso e cobertura das terras no mapa original de Shida (2000).

\section{Classes de uso e cobertura das terras}

Reclassificação do mapa original (Shida, 2000)

1. uso antrópico: incluindo a agricultura permanente, temporária, de subsistência e outras áreas com padrões de uso antrópico, que incluem pasto antrópico e áreas desmatadas.
1. cana-de-açúcar e pasto antrópico: este agrupamento foi feito pelo fato de se utilizar fogo, tanto para o "manejo" do pasto, como para a colheita da cana-de-açúcar. A proximidade destas áreas em que se utiliza fogo, coloca em risco a integridade do PEV, deixando as suas glebas suscetíveis a incêndios. 
Tabela 4. Alterações nas classes de uso e cobertura do solo no mapa original de Shida (2000) (...continuação)

2. silvicultura: inclui monoculturas de Eucalyptus spp. e Pinus spp.

3. vegetação florestal de interflúvio: constitui-se de vegetação arbórea formando um dossel, principalmente floresta estacional semidecídua, cerradão e capoeira. O critério de inclusão utilizado foi a presença dessas fisionomias em solos vermelhos com drenagem livre (Furley, 1996), utilizando o mapa pedológico (IAC, 1982) (escala 1:100.000).

4. campo sujo/ pasto natural: vegetação natural, com estrato herbáceo contínuo e árvores esparsas e porções de solo exposto, onde não foram observadas claramente atividades antrópicas;

5. cerrado: inclui as fisionomias de cerrado sensu stricto e campo cerrado.
2. cultura perene: inclui neste estudo Eucalyptus grandis e Citrus spp.

3. Sem alterações.
4. Sem alterações. É importante ressaltar que, na área de estudo, esta classe aparece apenas no interior da gleba Pé-de-Gigante. Como as análises e propostas consideram as áreas de entorno (a partir do limite das glebas do PEV), esta classe não foi considerada nas análises realizadas neste estudo (índices da paisagem, por exemplo).

5. Sem alterações 
Tabela 4. Alterações nas classes de uso e cobertura do solo no mapa original de Shida (2000) (...continuação)

6. vegetação ripária: vegetação natural que acompanha os rios e córregos, degradada ou não. Engloba tanto florestas perenifólias quanto vegetação brejosa. Foi considerada vegetação ripária aquela que se apresentava em Solos Hidromórficos e planícies e terraços aluviais (IAC, 1982; Furley, 1996).
6. vegetação ripária: a única alteração nesta classe, foi a delimitação e separação das planícies de inundação em uma classe distinta.

7. Planícies de Inundação (várzeas): estas áreas foram delimitadas através da análise de imagens de satélite IKONOS e de acordo com a topografia (IBGE, 1971).

Esta categoria foi inserida no mapa de uso e cobertura das terras com o objetivo de se demarcar as áreas de preservação permanente dos cursos d'água a partir do leito maior sazonal, seguindo especificações do Código Florestal (Lei 4771/65), além da importância das áreas de várzea para a manutenção da qualidade da água e para a fauna como área de reprodução e habitat.

8. Áreas de expansão urbana e edificações: conglomerados de construções, como por exemplo, sedes de fazendas, pátio industrial de usina de cana-deaçúcar e áreas próximas a centros urbanos.

A figura 4 representa o mapa de uso das terras utilizado neste estudo, já com as modificações descritas na Tabela 4. 
$218885,629700, \quad 225091,087527, \quad 231296,545354, \quad 237502,003181$,

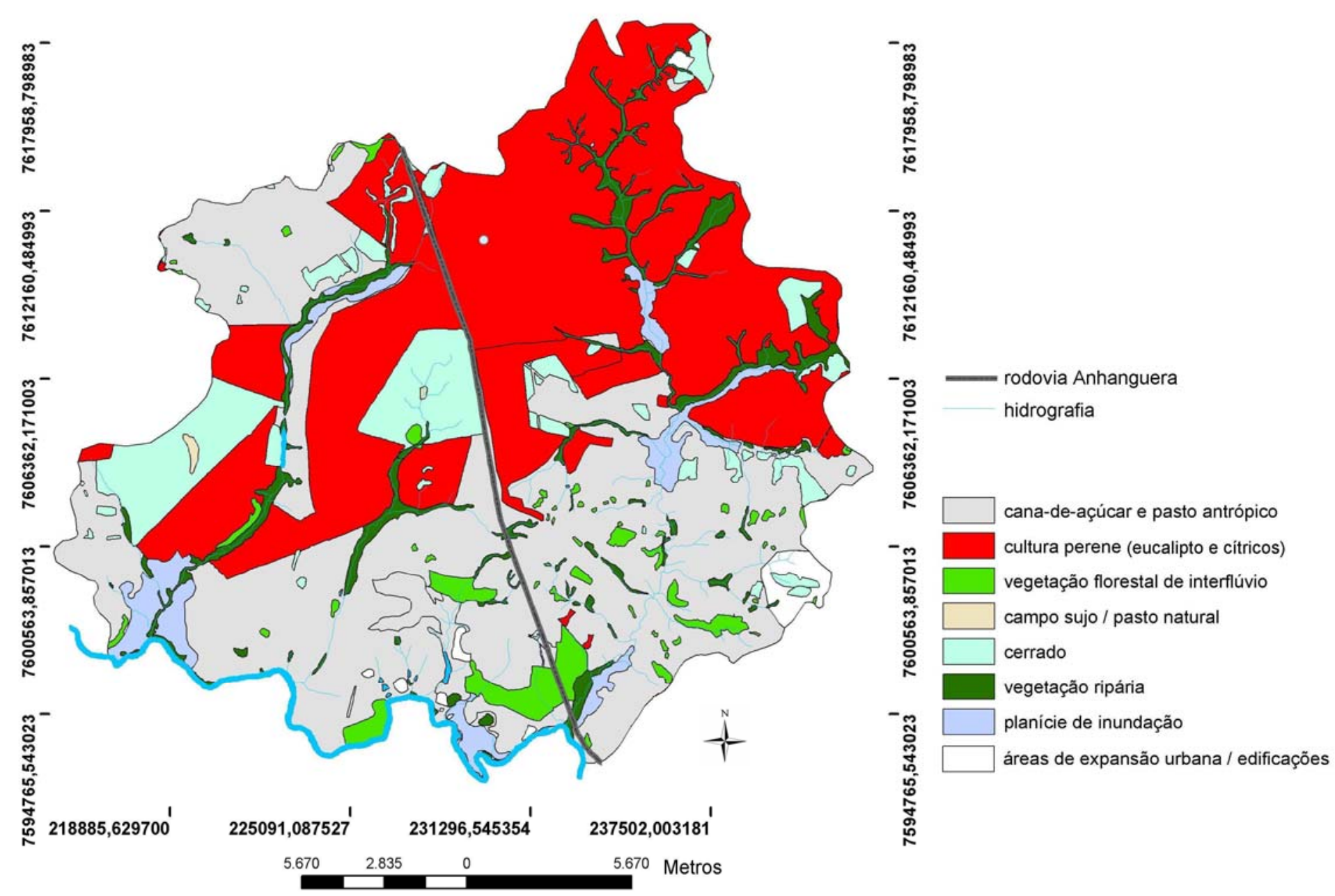

Figura 4 - Uso e Coberturas das Terras modificado a partir do mapa original de Shida (2000), conforme a tabela 4. 


\subsection{1 Índices da Paisagem}

A tabela 5 apresenta os valores dos índices da paisagem obtidos para as classes: vegetação florestal de interflúvio, cerrado e vegetação ripária.

Tabela 5. Índices da paisagem obtidos para as classes de vegetação nativa

\begin{tabular}{|c|c|}
\hline Índices & Valores / unidades \\
\hline Área Total da Paisagem (ATP) & 53.203 ha \\
\hline $\begin{array}{l}\text { Número de Manchas ou Fragmento (NM) } \\
\text { - cerrado } \\
\text { - vegetação florestal de interflúvio } \\
\text { - vegetação ripária }\end{array}$ & $\begin{array}{l}165 \\
48 \\
57 \\
60\end{array}$ \\
\hline $\begin{array}{l}\text { Porcentagem de vegetação nativa na paisagem (PVN) } \\
\text { - cerrado } \\
\text { - vegetação florestal de interflúvio } \\
\text { - vegetação ripária }\end{array}$ & $\begin{array}{l}16,10 \% \\
8,62 \% \\
3,35 \% \\
4,13 \%\end{array}$ \\
\hline $\begin{array}{l}\text { Tamanho Médio da Mancha (TMM) } \\
\text { - cerrado } \\
\text { - vegetação florestal de interflúvio } \\
\text { - vegetação ripária }\end{array}$ & $\begin{array}{l}81,60 \text { ha } \\
22,81 \text { ha } \\
33,30 \text { ha }\end{array}$ \\
\hline $\begin{array}{l}\text { Desvio Padrão do Tamanho das Manchas (DPTM) } \\
\text { - cerrado } \\
\text { - vegetação florestal de interflúvio } \\
\text { - vegetação ripária }\end{array}$ & $\begin{array}{c}247,91 \text { ha } \\
86,00 \text { ha } \\
67,96 \text { ha }\end{array}$ \\
\hline $\begin{array}{l}\text { Índice Médio de Forma (IMF) } \\
\text { - cerrado } \\
\text { - vegetação florestal de interflúvio } \\
\text { - vegetação ripária }\end{array}$ & $\begin{array}{l}1,65 \\
1,49 \\
2,23\end{array}$ \\
\hline $\begin{array}{l}\text { Porcentagem de Área Nuclear } \\
\text { - cerrado } \\
\text { - vegetação florestal de interflúvio } \\
\text { - vegetação ripária }\end{array}$ & $\begin{array}{l}41,4 \% \\
10,7 \% \\
10,2 \%\end{array}$ \\
\hline $\begin{array}{l}\text { Índice de Proximidade Média }(1 \text { km) } \\
\text { - cerrado } \\
\text { - vegetação florestal de interflúvio } \\
\text { - vegetação ripária }\end{array}$ & $\begin{array}{l}81,52 \\
22,06 \\
17,42\end{array}$ \\
\hline
\end{tabular}


As métricas da paisagem apresentadas na Tabela 5 indicam a fragmentação e o isolamento da vegetação nativa na paisagem.

$\mathrm{Na}$ área de estudo, existem 173 fragmentos de vegetação nativa; sendo apenas $6,2 \%$ da paisagem composta por vegetação nativa. As porcentagens mais baixas são para a vegetação florestal de interflúvio e vegetação ripária $1,1 \%$ e $1,8 \%$, respectivamente. Estes dados são importantes para subsidiar as propostas de implantação de corredores e restauração de áreas degradadas (principalmente através do reflorestamento de áreas anteriormente desmatadas), aumentando-se o número de habitats, principalmente das classes vegetação florestal de interflúvio e vegetação ripária. Forman \& Collinge (1997), após conduzirem estudos utilizando um modelo espacial para avaliar mudanças na paisagem e as consequências ecológicas provocadas por estas alterações, concluem que o planejamento espacial é importante quando 10 a $40 \%$ da vegetação natural é removida. De acordo com Shida (2000), no caso dos cerrados da região, houve uma redução de 33\% da vegetação em 35 anos, indicando a urgente necessidade de se implantar na área de estudo projetos de restauração dos ecossistemas nativos que foram ao longo dos anos degradados.

Analisando-se o tamanho médio dos fragmentos, verifica-se que o cerrado apresenta tamanho médio de apenas 81,60 ha, porém, com desvio padrão elevado. Este alto desvio padrão pode ser explicado pela presença de dois fragmentos maiores que a média dos fragmentos de cerrado presentes na paisagem: a gleba Pé-de-Gigante, com área aproximada um pouco superior a 1200 ha, e parte do fragmento, também pertencente ao Intituto Florestal - a Estação Experimental de Luíz Antônio - com 1.550 ha.

A área média dos fragmentos de vegetação florestal de interflúvio é de 22,81 ha e da vegetação ripária, 33,30 ha. Estes valores indicam que, em média, os fragmentos de vegetação nativa na área de estudo são pequenos para muitas espécies da fauna silvestre, principalmente aquelas que requerem grandes áreas de vida. 
O tamanho reduzido dos fragmentos agrava-se com a análise conjunta do índice de densidade de forma. Este índice analisa o formato dos fragmentos: para valores maiores que 1 , os fragmentos apresentam formato retangular, ou não circular. A proporção de área nuclear, ou seja, a área do fragmento sem influência de efeitos de borda, é maior em fragmentos circulares do que em fragmentos com formato retangular (Murcia, 1995; Collinge, 1996). Os valores de densidade de borda obtidos indicam formato irregular dos fragmentos de vegetação nativa, uma vez que todos os índices foram maiores que 1 , sendo 2,23 para a vegetação ripária, 1,65 para as fisionomias de cerrado e 1,49 para a vegetação florestal de interflúvio. O maior valor para a vegetação ripária explica-se pelo fato desta vegetação apresentar-se naturalmente em faixas lineares, acompanhando os cursos d'água.

Os fragmentos de vegetação nativa remanescentes na paisagem são, portanto, pequenos e sob grande influência da borda. $O$ índice de porcentagem de área nuclear confirma este fato. A porcentagem de área dos fragmentos sem influência dos efeitos de borda foi inferior a $50 \%$ nas três classes, sendo $41,4 \%$ para o cerrado e apenas 10,7\% e 10,2\% para a vegetação florestal de interflúvio e vegetação ripária, respectivamente. Estes resultados indicam que mais da metade das classes de vegetação nativa sofre influência dos efeitos de borda, sendo a situação mais crítica para as classes vegetação florestal de interflúvio e vegetação ripária.

Analisando-se o grau de isolamento das classes de vegetação nativa, através do índice de proximidade média, dentro do raio estabelecido de $1 \mathrm{~km}$, as que apresentaram maior grau de isolamento foram: vegetação ripária, com índice de 17,42 e vegetação florestal de interflúvio, 22,06.

As métricas da paisagem obtidas indicam a importância de se implantar procedimentos que aumentem a conectividade da paisagem e o tamanho dos fragmentos de vegetação nativa remanescentes. Algumas alternativas seriam o aumento das glebas do PEV (principalmente as glebas compostas por 
vegetação florestal de interflúvio) e a restauração de áreas para a implantação de corredores (utilizando espécies dos ecossistemas a serem recuperados), além de procedimentos mitigadores da influência dos efeitos de borda.

4.1.2 Diagnóstico de campo dos problemas ambientais decorrentes do uso do terras

Analisando-se somente os pontos localizados nas áreas de entorno e não considerando os locais visitados no interior das glebas do PEV, verifica-se que a totalidade $(100 \%)$ dos pontos visitados está em desacordo com a legislação ambiental ou apresentam problemas decorrentes do uso das terras.

Os principais problemas ambientais verificados em campo, estão descritos a seguir:

a) assoreamento dos mananciais e dos corpos d'água, principalmente em locais com declive acentuado, terraços ausentes ou rompidos e com plantio de cana-de-açúcar; 


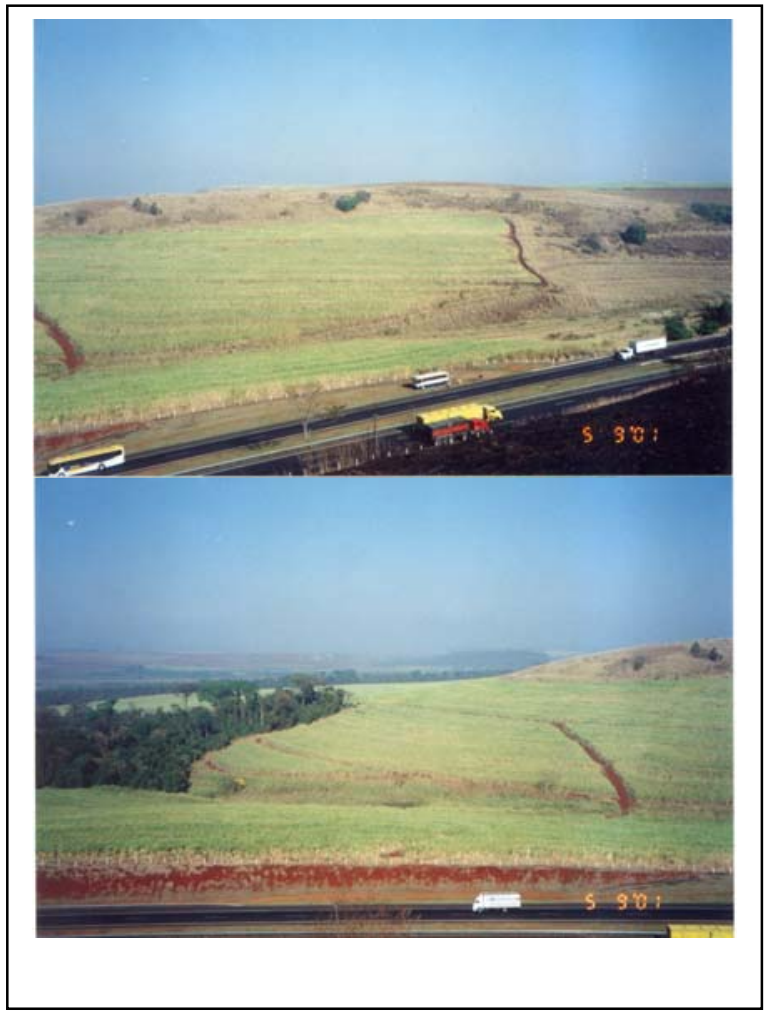

Figura 5 - Córrego assoreado sendo utilizado como área de pastagem.

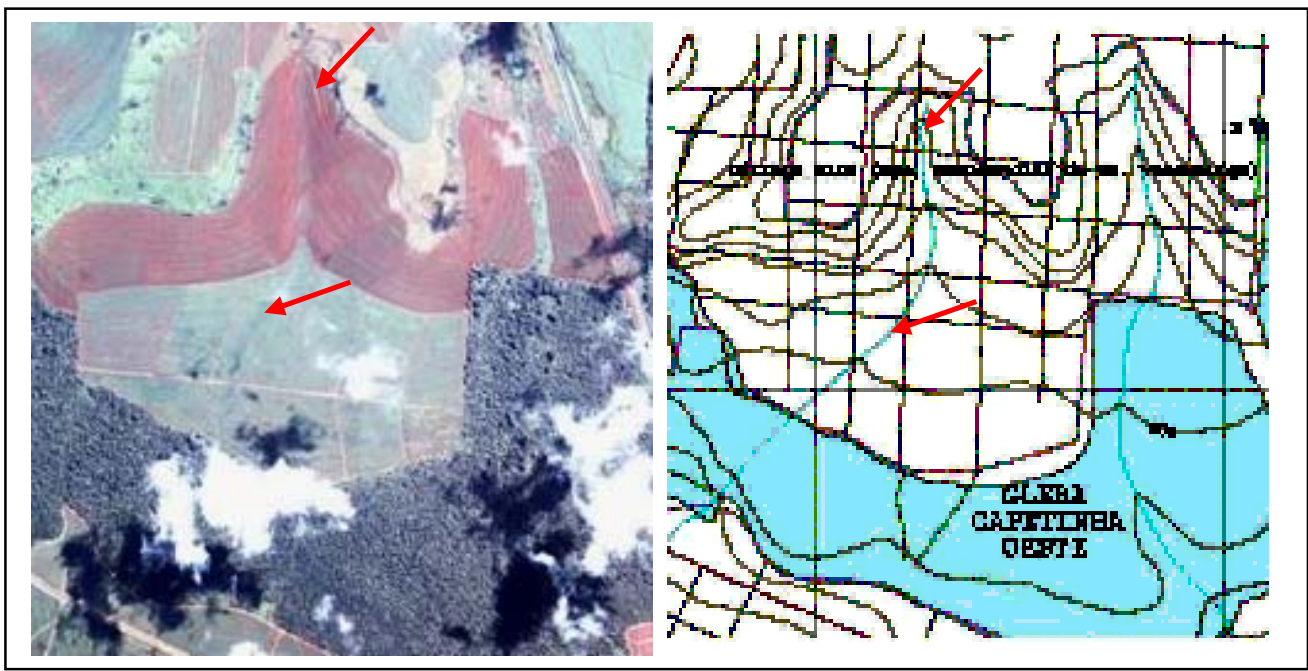

Figura 6 - Comparação entre a imagem de satélite Ikonos (2002) e a carta do IBGE (1971) digitalizada. Esta comparação permite identificar o curso d'água que desapareceu com o represamento de sua nascente (setas). 
b) Plantio de culturas agrícolas, roçadas em pastagens e outros usos dentro das faixas de preservação permanentes dos cursos d'água ou o abandono dessas áreas após o uso, sem que ocorra a recuperação.

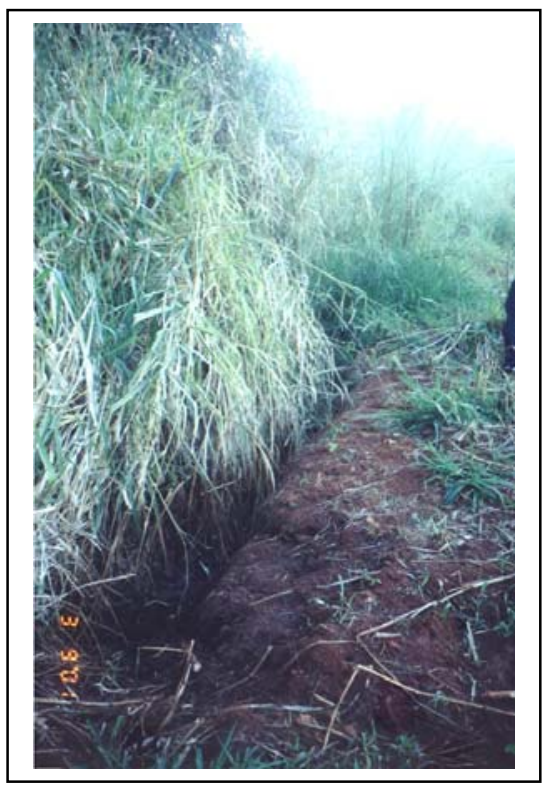

Figura 7 - Desvio do leito do córrego próximo à gleba Maravilha e tanques de decantação da Usina.

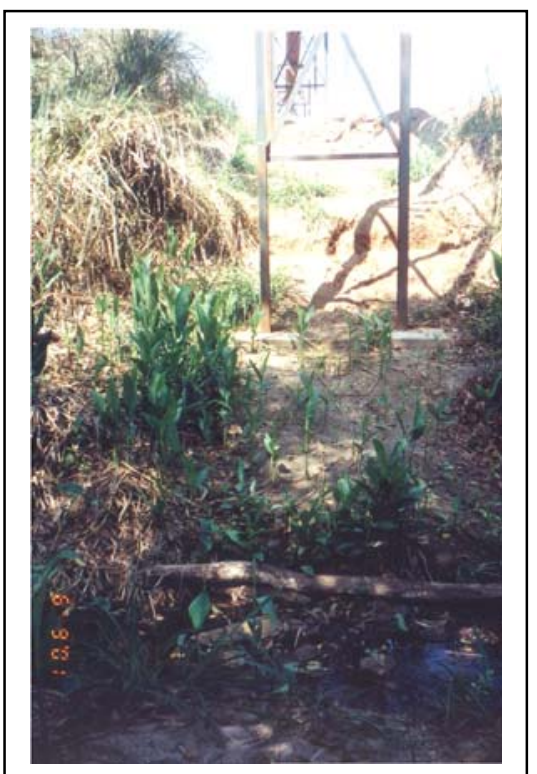

Figura 8- Aterro da APP do córrego da Água Santa para passar tubulação de vinhaça.

c) Depósito de lixo e restos de culturas agrícolas nas bordas das glebas e de outros fragmentos de vegetação nativa;

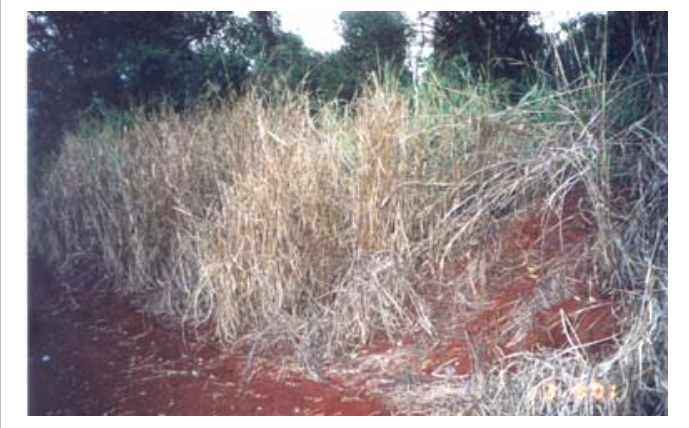

Figura 9 - Terra e restos de cultura empurrados em direção ao Pé-de-Gigante.

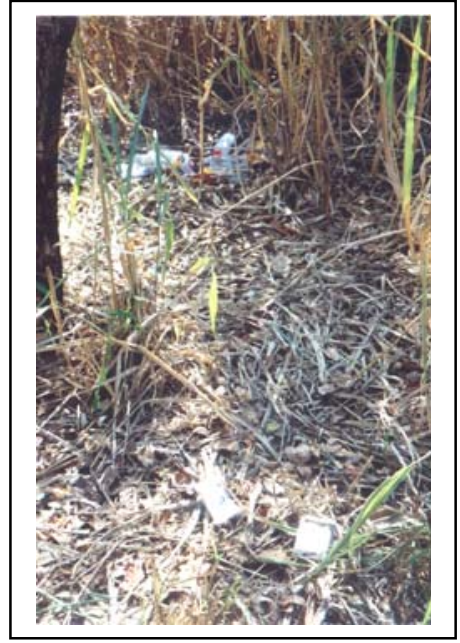

Figura 10 - Lixo na APP do rio Mogi Guaçu. 
d) Ausência de aceiros com larguras igual ou superior a dez metros;

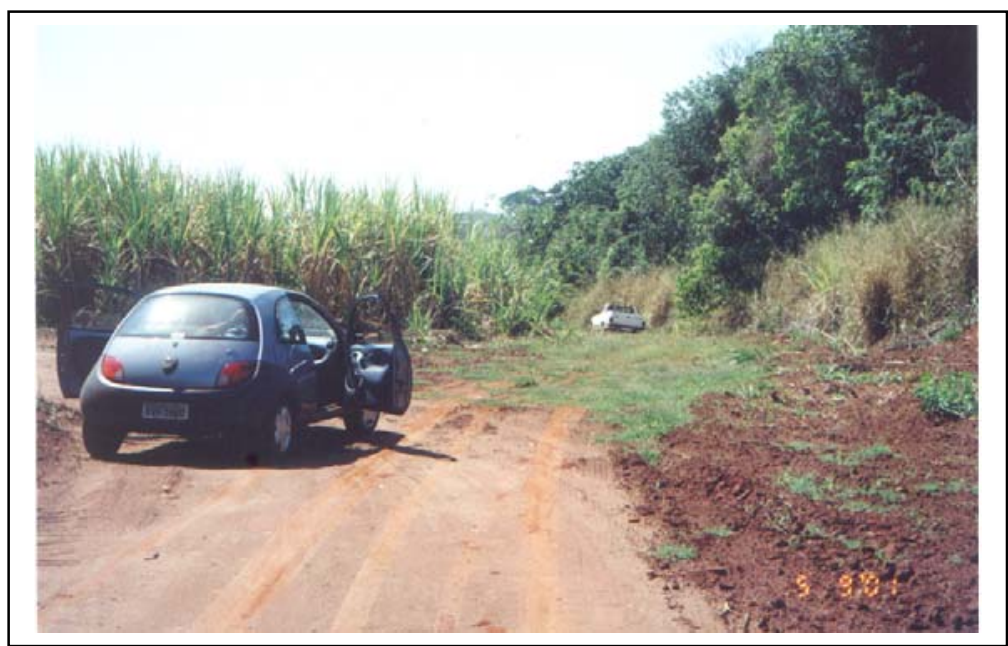

Figura 11 - Implantação de aceiro pela Usina da região apenas até o limite da área autuada.

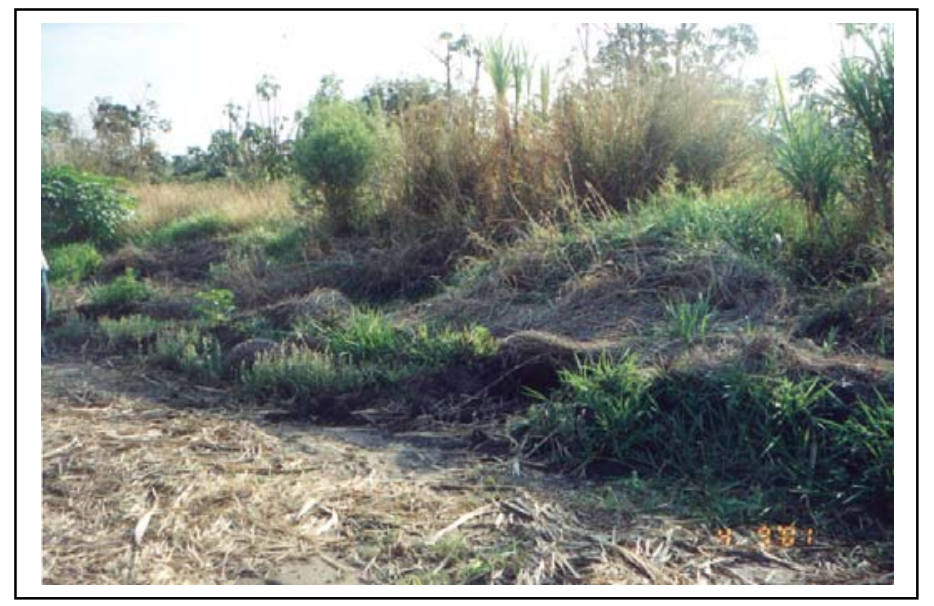

Figura 12 - Exemplo da ausência de aceiro entre a cultura da cana-de-açúcar e a APP do curso d'água e a prática de se empurrar restos de cultura em direção a APP. 
e) Uso de fogo para a colheita da cana-de-açúcar e/ou a queima da palha no chão e a queima no manejo do pasto;

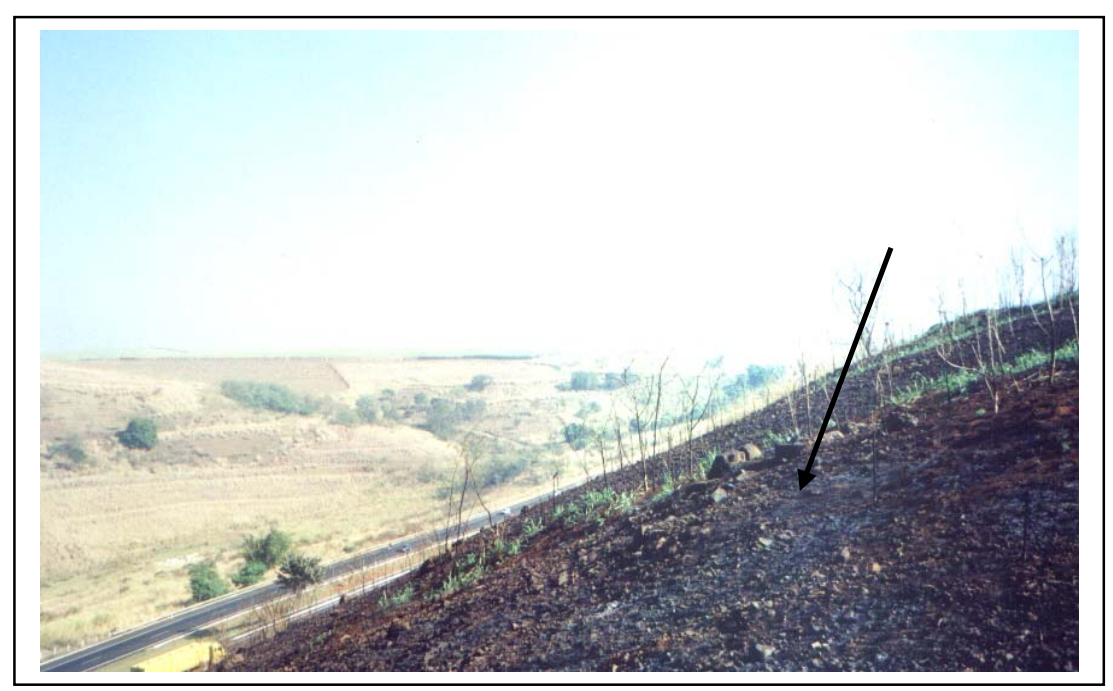

Figura 13 - Uso de fogo nas proximidades. Este morro faz divisa com a gleba Capetinga Leste.

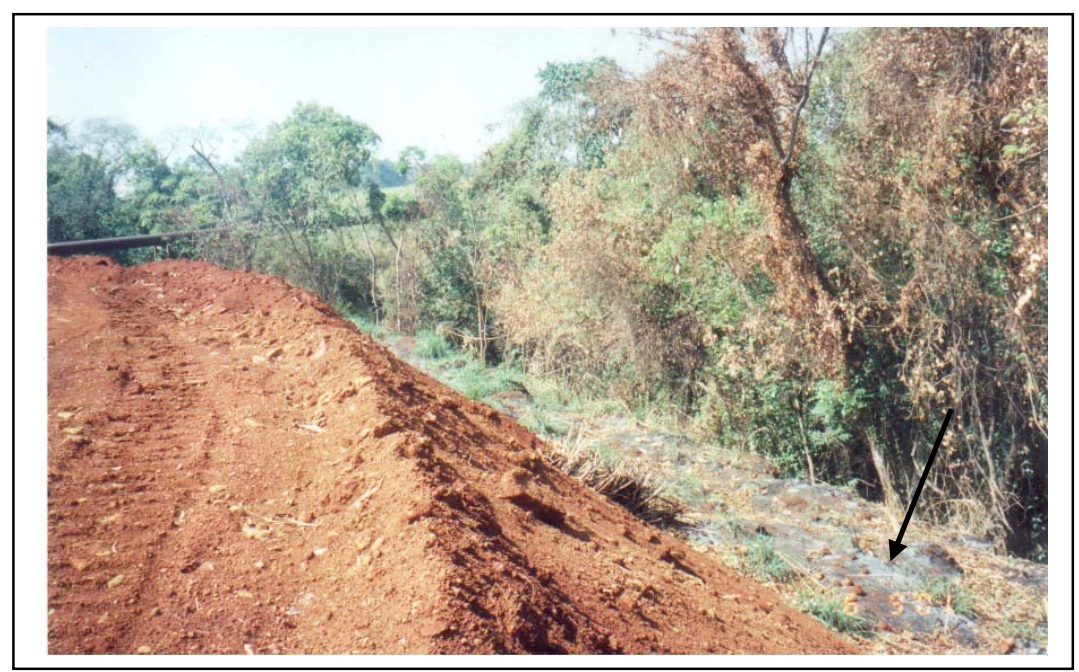

Figura 14 - Mesmo local da Fig. 8. Além do aterro na APP do córrego, a "limpeza" da área está sendo realizada com fogo. 
f) Presença de cevas e armadilhas nos fragmentos de vegetação nativa e indícios de cevas no interior das glebas. Estes indícios de caça encontrados no decorrer dos levantamentos de campo vão de encontro com os resultados obtidos por Jorge (1999), que entrevistou moradores da região do entorno da gleba Pé-de-Gigante. Segundo a autora, grande parte dos entrevistados vê com frequência caçadores na região e a maneira mais utilizada para praticar esta caça é com o uso de espingarda, seguida por cachorros e armadilhas. Entre os animais preferidos dos caçadores, estão o cateto, veado, capivara e tatu.
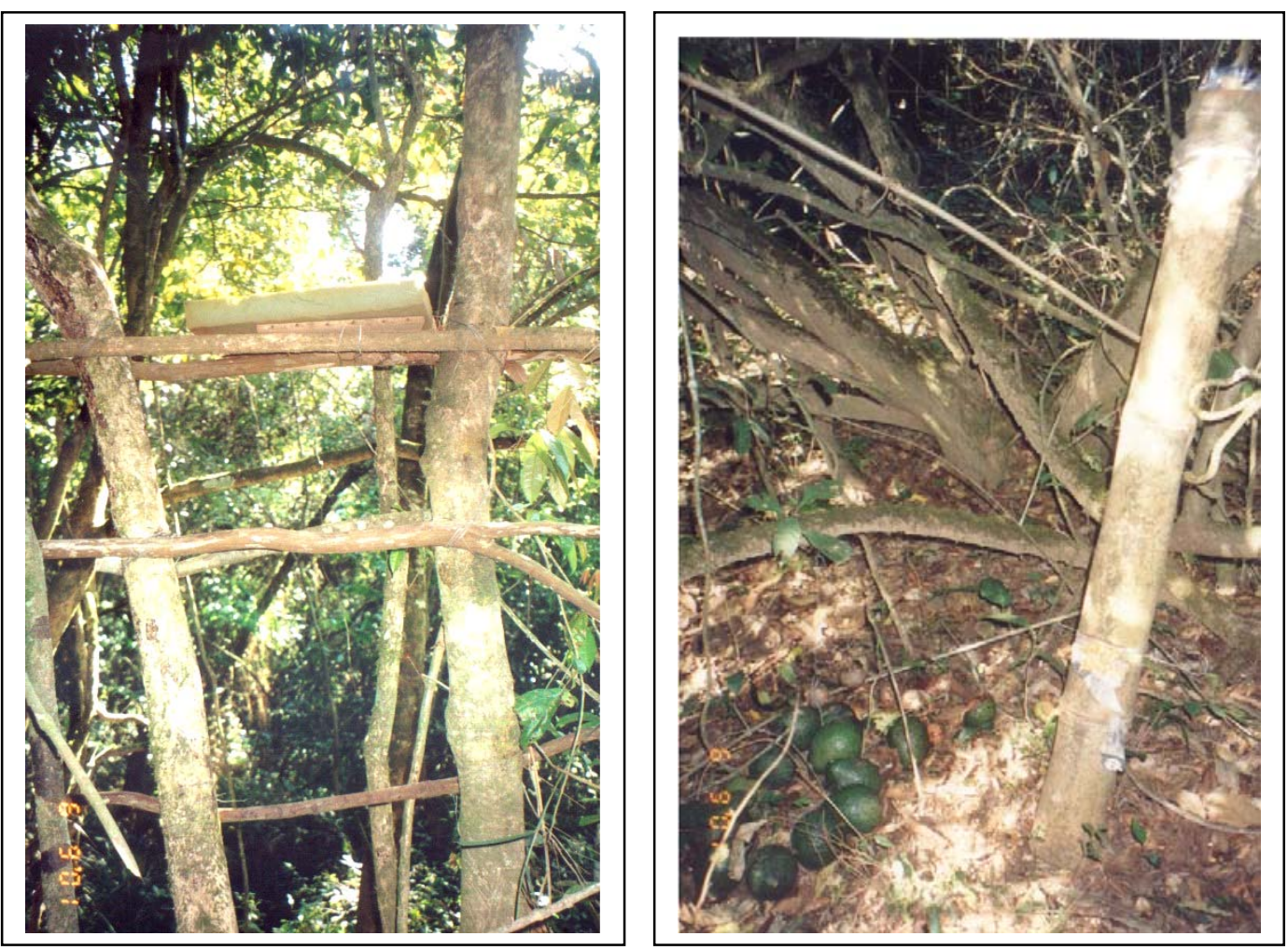

Figuras 15 e 16 - Uso de ceva para a caça de animais silvestres. Nesta estrutura construída em cima de uma árvore - no interior da APP do rio Mogi-Guaçu - o caçador espera a sua presa que irá se alimentar da ceva colocada no chão (à direita). 
g) Dimensionamento inadequado do sistema de galerias pluviais das rodovias, direcionados diretamente e sem dissipadores de energia, em direção às glebas e fragmentos de vegetação nativa;

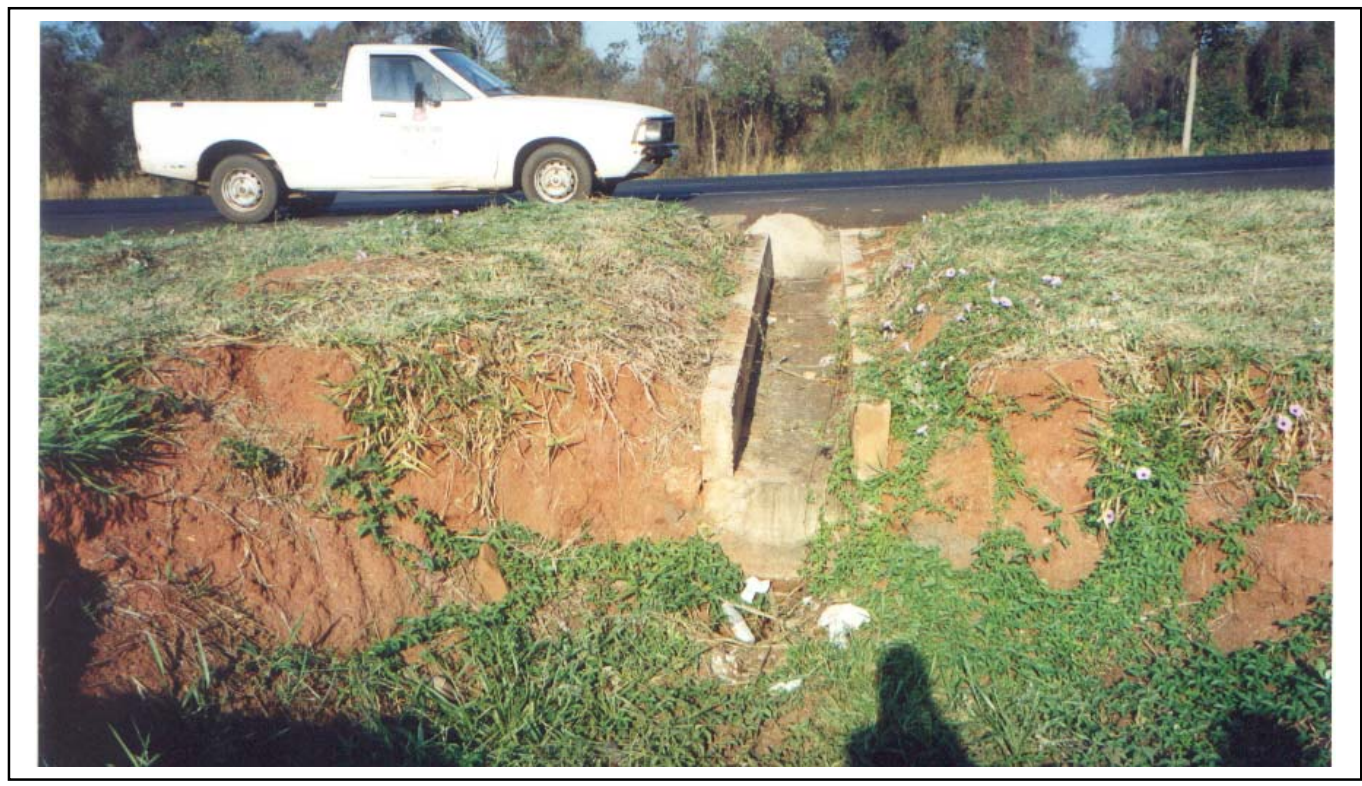

Figura 17 - Condução das águas pluviais da Rodovia Anhanguera em direção a gleba Capetinga Leste.

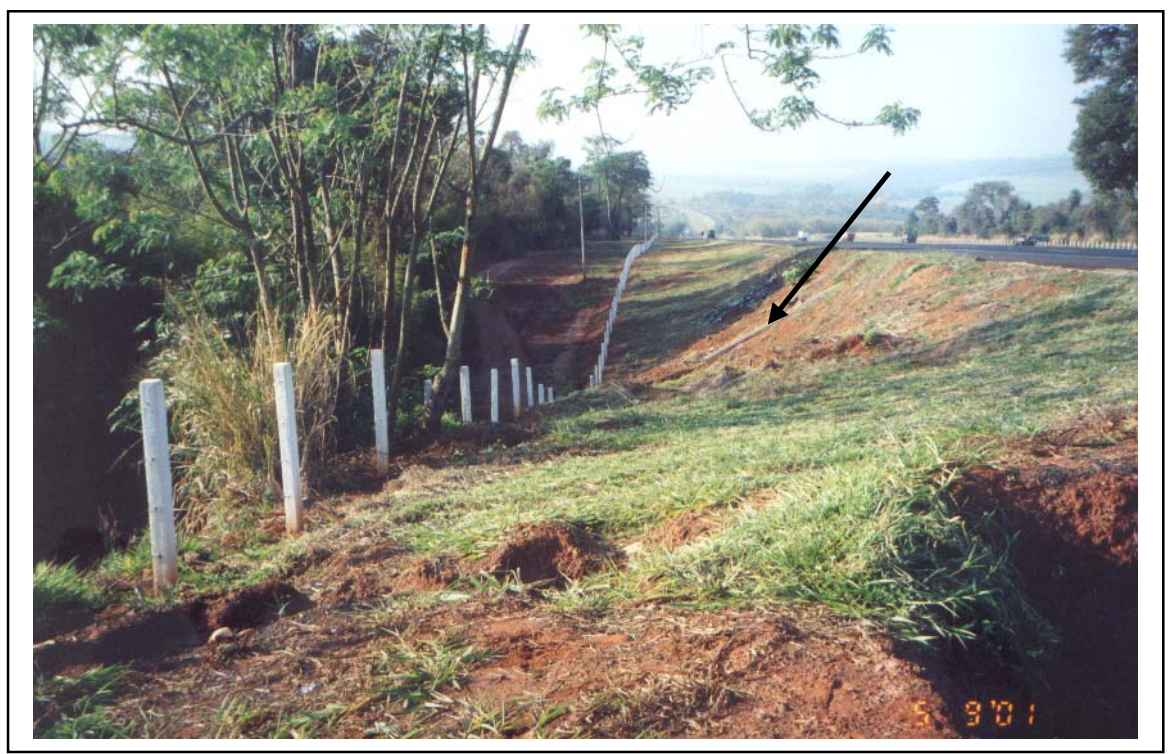

Figura 18 - Galeria sem dissipador de energia, direcionando a água para a gleba do PEV. 
h) Ausência de dispositivos de proteção para a fauna silvestre na rede viária. No decorrer dos levantamentos de campo, verificou-se a alta velocidade dos veículos (caminhões e automóveis), tanto na rodovia Anhangüera, como nas vicinais e carreadores. A ocorrência de atropelamentos de animais silvestres na região é freqüente (Jorge,1999; Ribeiro, H.J. com. pess.). Jorge (1999) registrou a ocorrência de atropelamentos de alguns animais no entorno da gleba Pé-de-Gigante, incluindo um exemplar de lobo-guará (Chrysocyon brachyurus) na via Anhanguera (em frente à gleba), um tamanduá-bandeira atropelado também nesta rodovia e um tatu, que foi atropelado na estrada asfaltada que ligava a cidade de Luiz Antônio à Rodovia Anhanguera.
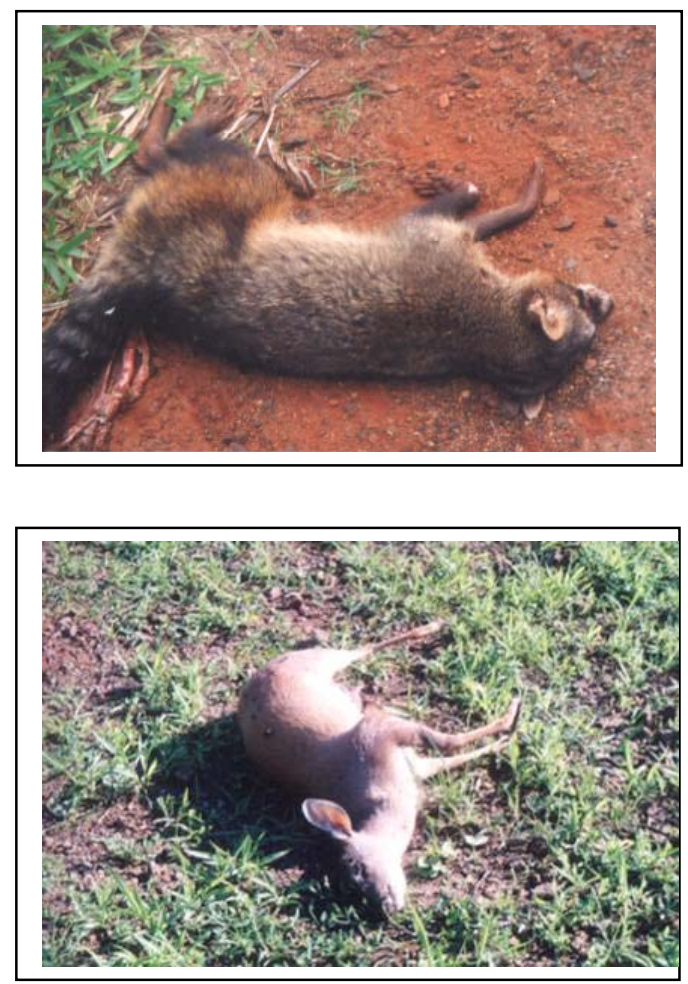

Figuras 19 e 20 - Animais atropelados nas rodovias e estradas vicinais da região. 
Outros procedimentos de ocorrência na área de estudo se relacionam às práticas de pulverizações aéreas de defensivos agrícolas e treinos e acrobacias realizados pela Academia da Força Aérea de Pirassununga sobre as glebas do PEV.

Os pontos amostrados em campo com um receptor de GPS estão espacializados na Figura 21 e descritos em detalhe na Tabela 6. 


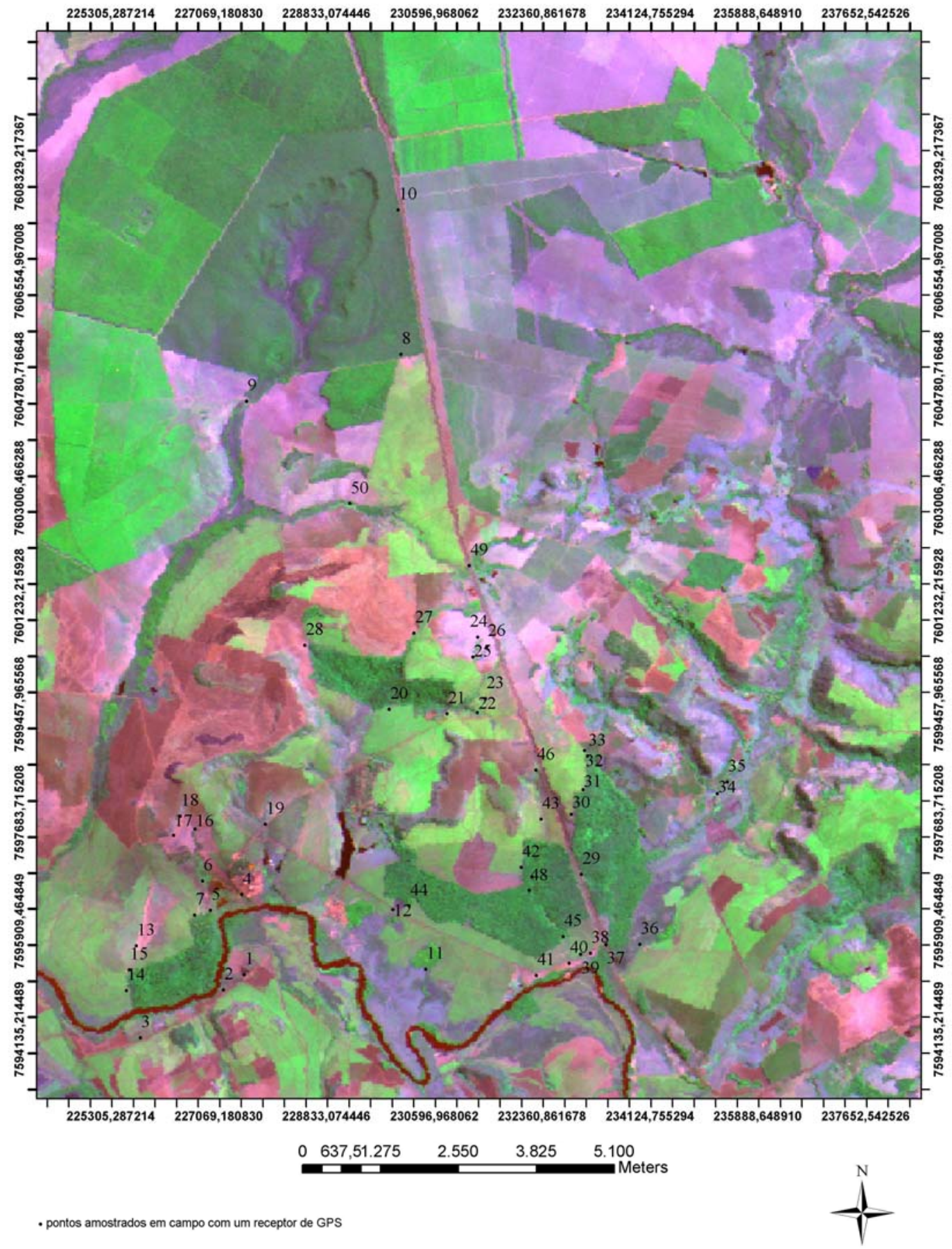

Figura 21 - Sobreposição em uma imagem de satélite Landstat $7 \mathrm{ETM}^{+}(2001)$ dos pontos amostrados em campo e descritos na Tabela 6. 
Tabela 6. Pontos amostrados na área de estudo e a descrição das irregularidades ambientais frente à legislação ambiental, decorrentes dos tipos de uso das terras.

\begin{tabular}{|c|c|c|}
\hline Ponto & Coordenadas (UTM) & Descrição \\
\hline 1 & $226769 / 7594245$ & $\begin{array}{l}\text { Margem esquerda do rio Mogi-Guaçu: aceiro ausente; } \\
\text { culturas agrícolas nas APPs próximas. }\end{array}$ \\
\hline 2 & $226428 / 7593995$ & $\begin{array}{l}\text { Próximo à gleba Maravilha: pasto dentro da área de } \\
\text { preservação permanente de } 100 \mathrm{~m} \text { do rio Mogi-Guaçu. }\end{array}$ \\
\hline 3 & $225071 / 7593206$ & $\begin{array}{l}\text { Extremidade oeste da gleba Maravilha. Neste local é } \\
\text { possível visualizar o aceiro estreito entre a cana e a } \\
\text { gleba e o efeito de borda e restos de cultura empurrados } \\
\text { em direção à gleba, formando um "cordão compacto" de } \\
\text { terra e gramíneas. }\end{array}$ \\
\hline 4 & $226730 / 7595550$ & $\begin{array}{l}\text { Tanques de decantação da Usina Santa Rita S/A. Açúcar } \\
\text { e Álcool: erosão e o carreamento de solo e particulados } \\
\text { que se acumulam na cota mais baixa do terreno. }\end{array}$ \\
\hline 5 & 226212 / 7595293 & Desvio de curso d'água próximo à gleba Maravilha \\
\hline 6 & 226085 / 7595783 & $\begin{array}{l}\text { Idem ao ponto 5: desvio do leito do córrego próximo à } \\
\text { gleba Maravilha e tanques de decantação da Usina } \\
\text { Santa Rita S/A. }\end{array}$ \\
\hline 7 & 225954 / 7595214 & $\begin{array}{l}\text { Face norte da gleba Maravilha: o aceiro possui largura } \\
\text { média entre } 4-5 \text { metros; capim com altura aproximada de } \\
4 \text { metros na borda da gleba. }\end{array}$ \\
\hline \multirow[t]{2}{*}{8} & 229329 / 7604407 & $\begin{array}{l}\text { Divisa com a gleba Pé-de-Gigante (face sul): restos da } \\
\text { cultura da cana-de-açúcar empurrados em direção à } \\
\text { gleba após a colheita. }\end{array}$ \\
\hline & & $\begin{array}{l}\text { Em trecho à jusante, entre a gleba e um eucaliptal, } \\
\text { construção de "bacias secas", para captação das águas } \\
\text { pluviais e manutenção da estrada, no limite da vegetação } \\
\text { de cerrado, favorecendo o crescimento de gramíneas } \\
\text { invasoras (como já está ocorrendo). }\end{array}$ \\
\hline 9 & $226806 / 7603635$ & $\begin{array}{l}\text { Córrego Paulicéia. Há mais de dois anos este local } \\
\text { pegou fogo (Ribeiro, H.J., com.pess.). Verifica-se a } \\
\text { presença de cipós e gramíneas exóticas. }\end{array}$ \\
\hline
\end{tabular}


Tabela 6. Pontos amostrados na área de estudo e a descrição das irregularidades ambientais frente à legislação ambiental, decorrentes dos tipos de uso das terras (Continuação).

Face leste da gleba Pé-de-Gigante, divisa com a rodovia Anhanguera: presença de lixo, como embalagens de produtos, sacos plásticos e restos de alimentos jogados na rodovia pelos veículos.

Em vários locais o crescimento de gramíneas exóticas é intenso, atingindo uma média de 30 a 40 metros no interior da gleba. Em um ponto específico, onde foi construído um canal de drenagem (para escoar a água da estrada em direção a gleba), a faixa de capim atinge aproximadamente 80 metros no interior da gleba.

$11 \quad 229738 / 7594332$

Área limítrofe da gleba Capão da Várzea: cerca de arame e gado em área de nascente; solo hidromórfico, sendo ocupado com cana e pasto; queima da palha da cana após colheita mecânica.

Local de manancial com a presença de mata ciliar, mas as bordas invadidas por capim exótico e os aceiros são estreitos. Esta vegetação ripária é interrompida por uma estrada asfaltada. É provável que o curso d'água que foi represado, em área acima da gleba Capetinga Oeste, unia-se a este manancial, desaguando no rio MogiGuaçu.

$13 \quad 225002 / 7594711$

Pista de vôo. Na área de estudo é comum a aplicação aérea de herbicida e defensivos agrícolas.

Face oeste da gleba Maravilha: há uma faixa de aceiro com apenas 5 metros de largura. $O$ local é íngreme, suscetível à erosão e terra e restos de cultura foram empurrados na borda da gleba. Nas margens do Mogi, a APP não está delimitada a partir do leito maior sazonal, havendo plantio de cana dentro da APP.

Pequeno trecho que foi autuado pela Polícia Florestal e o único local amostrado com aceiro de dez metros. Após o limite da área autuada, verifica-se aceiros com a invasão de gramíneas exóticas e uma largura média de apenas quatro metros. córrego desviado (ver pontos 5 e 6 ). 
Tabela 6. Pontos amostrados na área de estudo e a descrição das irregularidades ambientais frente à legislação ambiental, decorrentes dos tipos de uso das terras (Continuação).

$17225610 / 7596529 \quad$ Idem ponto 16: desvio do curso d'água.

$18225720 / 7596845$ Provável localização da nascente do curso d'água desviado para a implantação dos tanques de decantação.

$19 \quad 227112 / 7596708$

Nascente sem aceiro e invasão de gramíneas; assoreamento.

$20 \quad 229137 / 7598590$

Face sul da gleba Praxedes: talhão de cana foi reformado; restos de cultura empurrados em direção à mata e ausência de aceiro.

$21 \quad 230086 / 7598521$

Área íngreme e cana de açúcar muito próxima à Gleba Praxedes: efeito de borda intensificado pelo processo erosivo acentuado.

Local próximo ao Córrego Rico e Gleba Praxedes: ocorrência de erosão, promovendo o assoreamento do córrego.

$23 \quad 230713 / 7598767$

Córrego Rico: assoreamento, ausência de aceiro; faixa de mata ciliar estreita, com restos de cana de açúcar. A declividade do local é acentuada e o solo possui textura arenosa. Observam-se terraços mal conservados.

$24 \quad 230587 / 7599446$

Local próximo às nascentes: cana na APP (margem esquerda) e, margem direita, 20 a 30 metros de APP com restos da cultura de cana e capim.

Local próximo ao encontro de duas nascentes. Aceiro estreito (média de 4 metros). Declive acentuado .

Local próximo à rodovia Anhanguera e uma nascente: não há aceiro de proteção entre a área da nascente e as áreas cultivadas. manancial, o leito está seco e assoreado. 
Tabela 6. Pontos amostrados na área de estudo e a descrição das irregularidades ambientais frente à legislação ambiental, decorrentes dos tipos de uso das terras (Continuação).

Aceiro próximo à outra nascente que passa pela gleba Praxedes tem apenas 4 metros de largura, está mal conservado e a borda do pequeno trecho de vegetação nativa remanescente encontra-se invadida por gramíneas exóticas e terra amontoada.

Rodovia com declive acentuado próximo a Gleba Capetinga Leste.

O sistema de controle do escoamento das águas pluviais por meio de canaletas retas ("morro abaixo"), praticamente sem um sistema dissipador de energia eficiente, causou a formação de voçoroca e a perda da única nascente que abastecia a Gleba Capetinga Leste.

Morro que faz divisa com a Gleba Capetinga Leste: carreador com declive acentuado.

Entre este morro e a Gleba, há acúmulo de terra e sedimento e invasão de capim nas bordas, aumentando o risco de ocorrência de incêndio.

$31 \quad 232309 / 7597276$

Extremidade norte da gleba Capetinga Leste: eucaliptos por entre a vegetação nativa, indicando que esta parte da gleba pode ter sido um talhão de eucalipto no passado. Mais abaixo há uma nascente no interior da gleba.

Divisa da gleba Capetinga Leste (face leste), onde predominam pequenas propriedades e plantio de pequenas áreas de café, pomar e pasto. Um ponto negativo a ser observado nesta área é o fato da maioria dos proprietários terem cães domésticos de grande porte e de caça, sendo uma ameaça à fauna silvestre (tanto nos aspectos da caça como na transmissão de doenças, para espécies como o lobo-guará e cachorro do mato).

Próximo ao rio Bebedouro: pomar de pequenas propriedades na APP. 
Tabela 6. Pontos amostrados na área de estudo e a descrição das irregularidades ambientais frente à legislação ambiental, decorrentes dos tipos de uso das terras (Continuação).

37 e $\quad 232650 / 7594750$

$38 \quad 232685 / 7594733$

39

$232430 / 7594592$

40

$232270 / 7594576$

41

$232084 / 7594430$

42

$231295 / 7596007$

43

$231624 / 7596791$

44

45

$232050 / 7594855$

$46 \quad 231541 / 7597594$

48
Margens do rio Bebedouro, próximo à rodovia Anhanguera: presença de mata ciliar, porém a continuidade da mata é interrompida pela rodovia.

Margem do rio Bebedouro (próxima à sua foz) com mata ciliar estreita (cerca de $5 \mathrm{~m}$ ) e o restante da faixa de preservação permanente com capim. O aceiro, com cerca de 5-6 m de largura, está com cana-de-açúcar.

Córrego da Gruta desprovido de mata ciliar (apenas capim); leito assoreado e cultivo de cana próximo da zona ripária.

Reflorestamento da Usina Santa Rita S/A (cerca de 100 metros de extensão por 30 metros de largura). Este trecho está sendo reflorestado por ter sido objeto de autuação. $\mathrm{O}$ aceiro de dez metros foi implantado apenas até o limite da área autuada. Nas proximidades, no interior da mata ciliar do rio Mogi-Guaçu, foram encontradas quatro cevas.

Extremidade norte da gleba Cepetinga Oeste. Aceiro de 4 metros de largura (média) e a invasão de gramíneas exóticas e cipós.

Córrego que passa no interior da Gleba Capetinga Oeste, próximo à Rodovia Anhanguera.

Situação Crítica: Curso d'água assoreado e capim alto por todo o leito. O declive é acentuado e solo suscetível à erosão.

Agravante: Única fonte de água para esta Gleba e que se encontra comprometida.

Divisa com a face sul da gleba Capetinga Oeste e local próximo ao Ponto 12: ausência de aceiro e invasão de espécies exóticas.

Ausência de aceiro de dez metros de largura.

Nascente próxima à rodovia Anhanguera: à jusante observa-se que o leito deste córrego está assoreado, com a invasão de gramínea exótica e a área está sendo utilizada como pastagem (vide Ponto 43).

231471 / $7595846 \quad$ Córrego da Gruta: curso d'água estreito (média de $80 \mathrm{~cm}$ de leito), próximo à trilha do Jequitibá, no inteior da gleba Capetinga Oeste. 
Tabela 6. Pontos amostrados na área de estudo e a descrição das irregularidades ambientais frente à legislação ambiental, decorrentes dos tipos de uso das terras (Continuação).

\begin{tabular}{ccl}
49 & $230447 / 7600941$ & $\begin{array}{l}\text { Encontro das } 3 \text { nascentes do Córrego da Água Santa: } \\
\text { assoreamento. }\end{array}$ \\
50 & $228491 / 7601962$ & $\begin{array}{l}\text { Córrego da Água Santa: leito assoreado e trechos sem } \\
\text { mata ciliar nas proximidades da rodovia Anhanguera. }\end{array}$ \\
\hline
\end{tabular}

As informações obtidas em campo foram importantes para direcionar as propostas de implantação de corredores e, principalmente, as propostas de uso para a matriz, procurando reverter os tipos de uso das terras que mais degradam os recursos naturais da área de estudo e aumentam o isolamento das glebas do PEV. Segundo Rodrigues et al. (2001), a influência negativa dos efeitos de borda ocorre em maior ou menor intensidade de acordo com os fatores de degradação do entorno. Os autores acrescentam que as áreas a serem restauradas devem ser isoladas dos fatores de degradação, como fogo (direto ou próximo, elevando a temperatura local), águas pluviais e outros.

4.1.3 Análise das APPs dos corpos d'água utilizando imagem de satélite IKONOS

O mapa apresentado na Figura 22, mostra o uso e cobertura atuais das áreas de preservação permanente, nas áreas de entorno das glebas do PEV. 


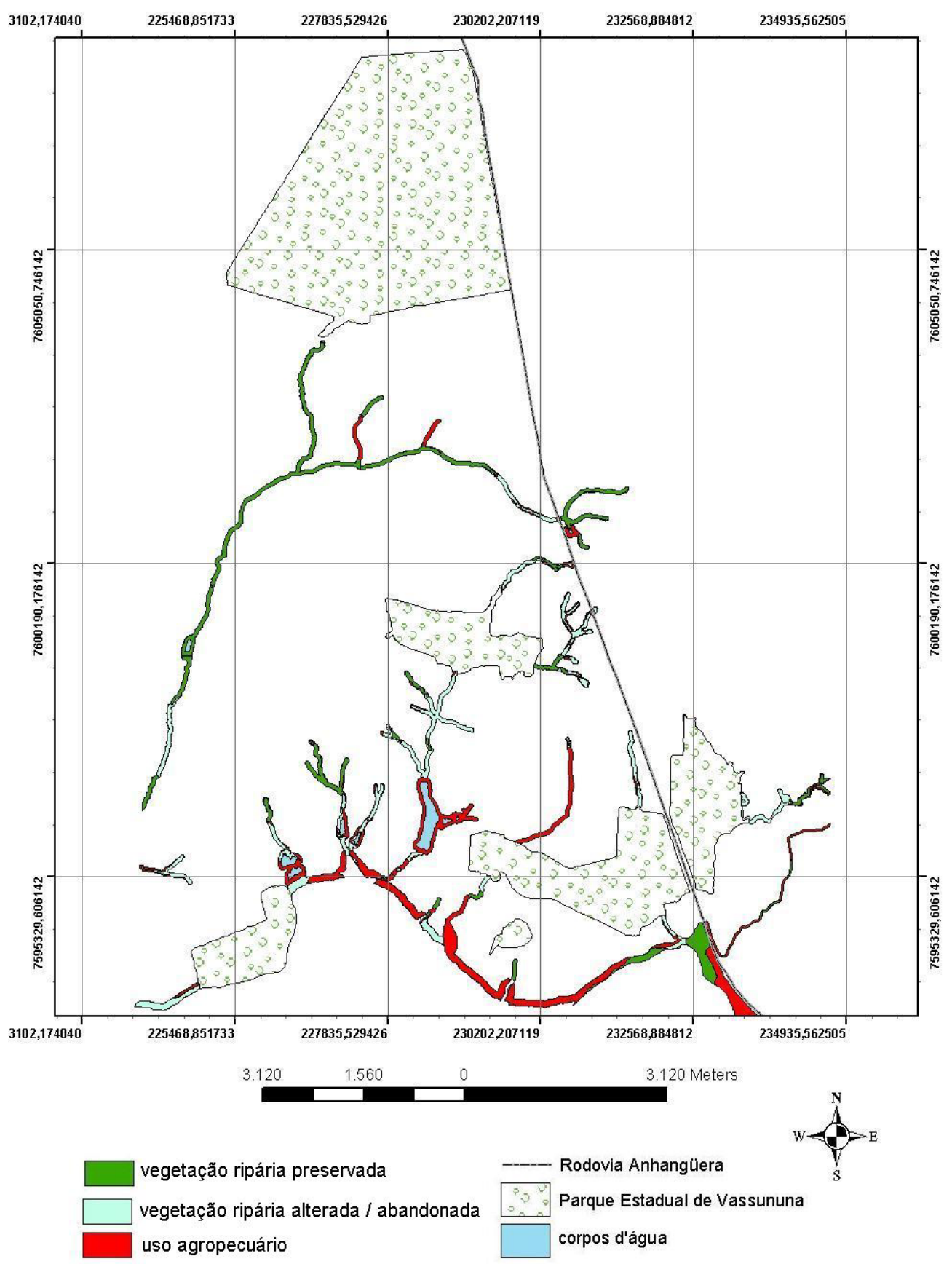

Figura 22 - Cobertura atual das Áreas de Preservação Permanente dos mananciais nos arredores do Parque Estadual de Vassununga. 
A matriz de erros (ou de confusão) (Quadro 1), revela a acurácia da classificação dos tipos de uso e cobertura das áreas de preservação permanente dos corpos d'água, nas imagens de satélite IKONOS (2002). A acurácia total da classificação foi de 93,3\% (sendo que o valor mínimo para aceitar uma classificação é de $85 \%$ ) e o coeficiente de concordância Kappa obtido foi de $\mathbf{0 , 8 9}$, o que corresponde a um desempenho de classificação excelente (Rosenfield \& Fitzpatrick-Lins, 1986).

\begin{tabular}{|c|c|c|c|c|c|c|}
\hline \multirow[b]{2}{*}{ Classificação } & \multicolumn{6}{|c|}{ Verdade } \\
\hline & $\begin{array}{l}\text { Vegetação } \\
\text { ripária } \\
\text { preservada }\end{array}$ & $\begin{array}{l}\text { Vegetação } \\
\text { ripária } \\
\text { alterada }\end{array}$ & $\begin{array}{l}\text { Uso } \\
\text { agrope- } \\
\text { cuário }\end{array}$ & $\begin{array}{c}\text { Total } \\
\text { Observado } \\
\text { (GPS) }\end{array}$ & $\begin{array}{c}\text { Erro } \\
\text { Omissão }\end{array}$ & Acurácia \\
\hline $\begin{array}{l}\text { Vegetação } \\
\text { ripária } \\
\text { preservada }\end{array}$ & 05 & 01 & 0 & 06 & $16,7 \%$ & $83,3 \%$ \\
\hline $\begin{array}{l}\text { Vegetação } \\
\text { ripária } \\
\text { alterada }\end{array}$ & 0 & 10 & 0 & 10 & $0 \%$ & $100 \%$ \\
\hline $\begin{array}{c}\text { Uso } \\
\text { Agropecuário }\end{array}$ & 0 & 01 & 13 & 14 & $7,1 \%$ & $92,9 \%$ \\
\hline $\begin{array}{c}\text { Total } \\
\text { Classificado }\end{array}$ & 05 & 12 & 13 & 30 & & \\
\hline Erro Omissão & $0 \%$ & $16,7 \%$ & $0 \%$ & & & \\
\hline Acurácia & $100 \%$ & $83,3 \%$ & $100 \%$ & & & \\
\hline
\end{tabular}

Quadro 1 - Matriz de Erros ou de Confusão comparando a classificação em campo com a classificação visual da imagem de satélite IKONOS, para as classes de uso e cobertura das terras das APPs.

Com esta margem de erro em relação à qualidade da classificação, realizou-se a quantificação das classes, conforme ilustra a Figura 24: 


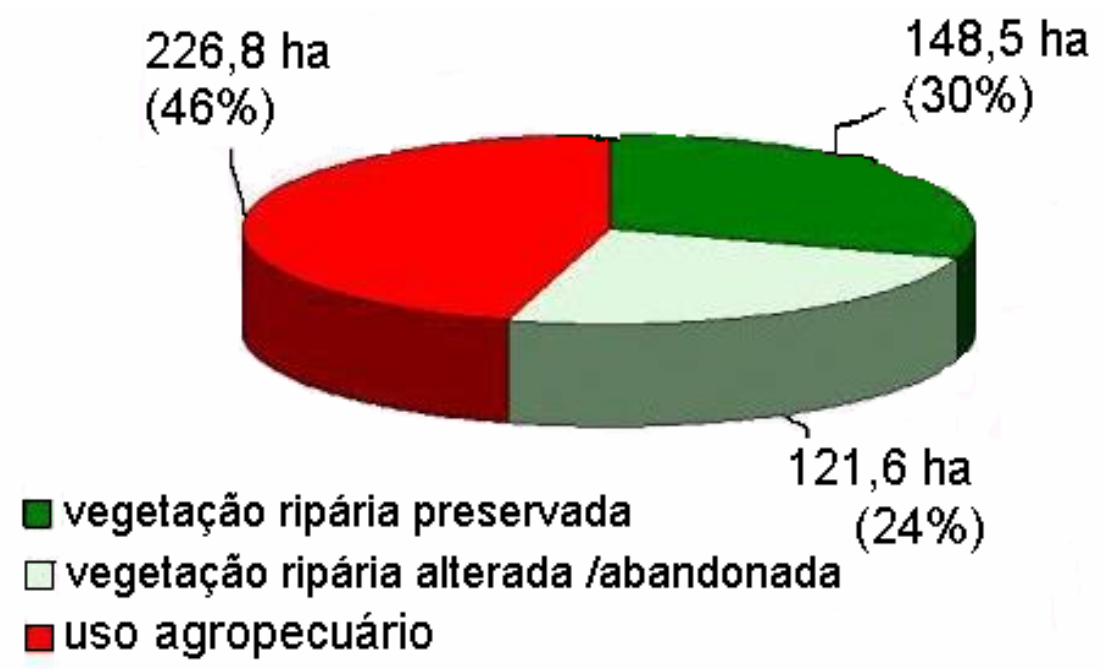

Figura 23 - Quantificação dos usos e ocupação das APPs, classificados na imagem de satélite Ikonos (2002) e aferições em campo.

Os resultados acima confirmam as conclusões obtidas com os índices da paisagem, que indicam ser a vegetação ripária a classe mais fragmentada e de menor ocorrência na paisagem. Centrando-se na importância das margens dos cursos d'água para a manutenção ou o incremento do fluxo gênico e para a proteção dos recursos hídricos, propostas para a recuperação da vegetação ripária são prioritárias.

4.1.4 Mapeamento de áreas de risco de erosão no entorno das glebas do PEV

O mapa de uso das terras e o mapa de solos foram utilizados para integrar os fatores cultural e de erodibilidade, respectivamente. Outro mapa desenvolvido e utilizado para a integração dos parâmetros da EUPS, foi o mapa do Fator LS (Figura 24). 


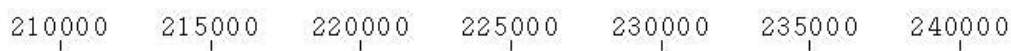

$615000-$

$610000-$

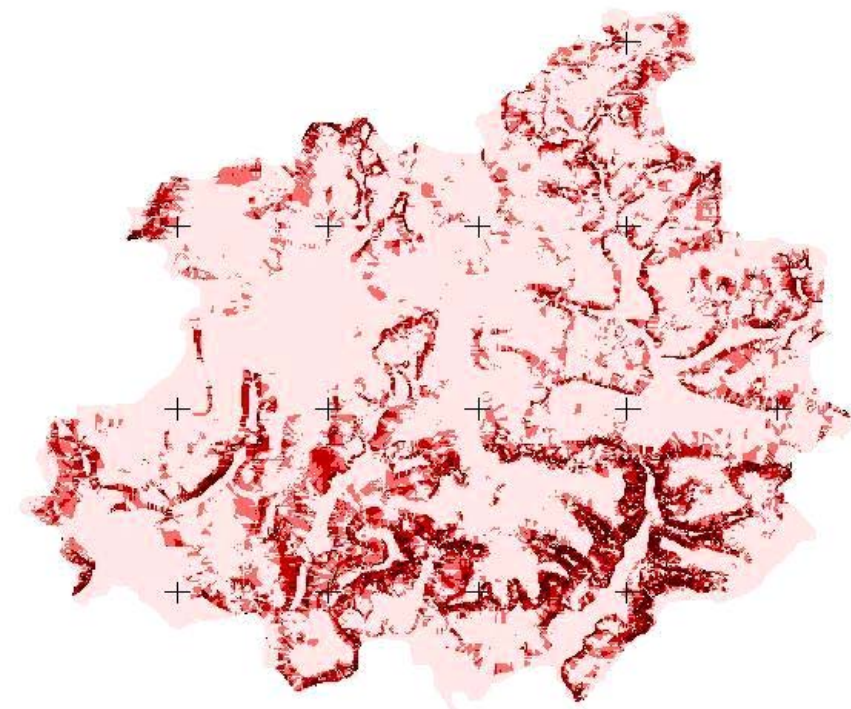

$595000+$

$205^{\prime} 000 \quad 210^{\prime} 000$

$215^{\prime} 000 \quad 220^{\prime} 000$

$225000 \quad 230000$

$235000 \quad 240000$

Fator LS

$0-2$
$2-4$
$4-10$
$>10$

10000

0

10000 metros

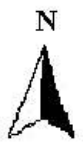

Figura 24 - Mapa do fator topográfico LS. 
O mapa de risco potencial de erosão, gerado com a integração dos planos de informações e dados manipulados, com base na EUPS, está apresentado na Figura 25.

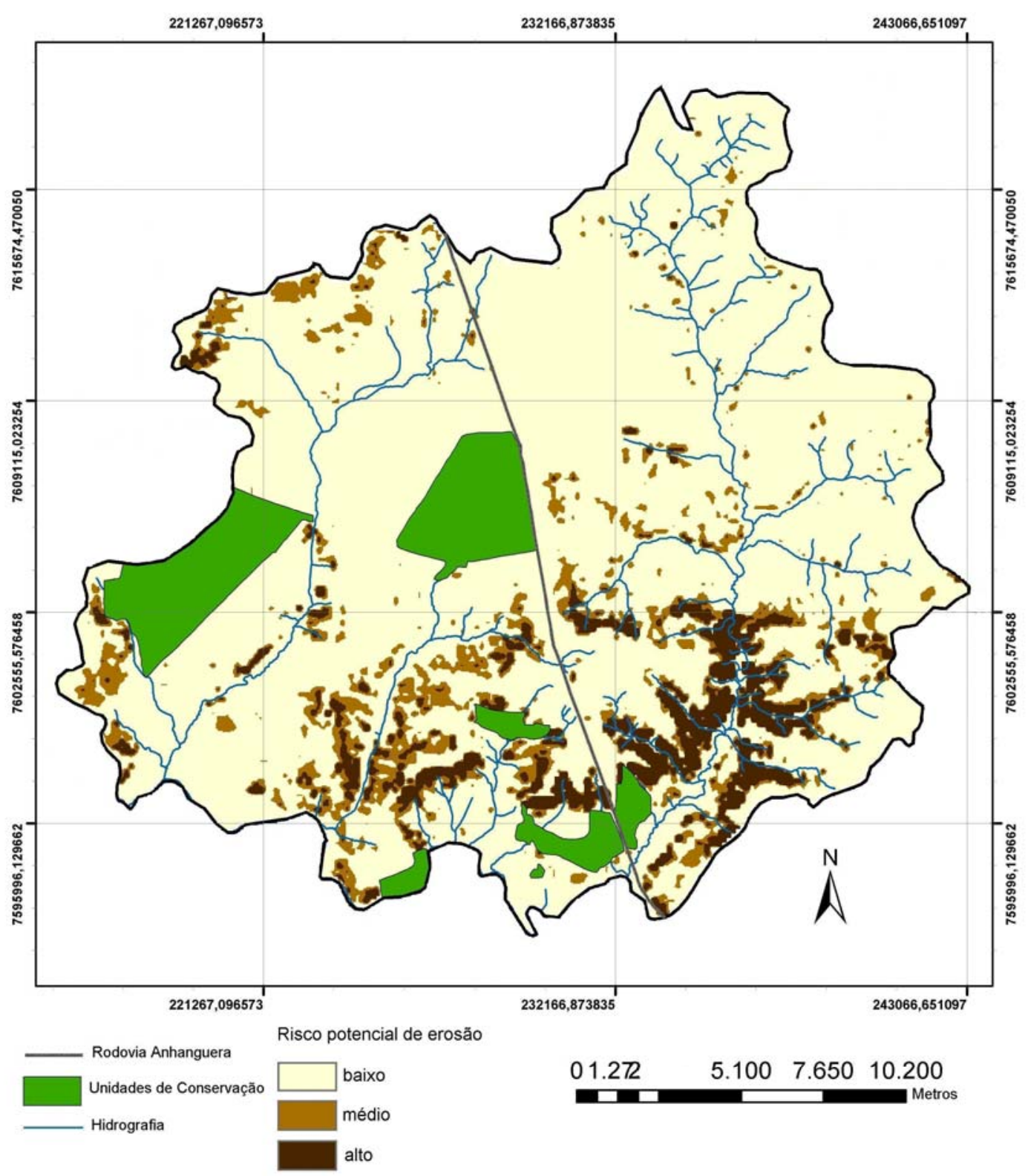

Figura 25 - Mapa de risco potencial de erosão na região de estudo. 
Observa-se na Figura 25 que as áreas indicadas como sendo de maior risco potencial de erosão estão localizadas nas nascentes e próximas aos cursos d'água.

Apesar da EUPS (Equação Universal de Perdas de Solo) ser uma equação empírica para estimar a perda de solo por unidade de área, a metodologia utilizada mostrou-se adequada. A porcentagem de acerto dos pontos amostrados em campo com erosão (Tabela 6) foi de $100 \%$.

Verifica-se que as áreas amostradas com a ocorrência de ravinas e voçorocas, mananciais assoreados e o desaparecimento de nascentes e cursos d'água coincidem com as categorias de riscos mais elevados de erosão do mapa de risco potencial de erosão.

Apesar da maioria dos estudos para determinar níveis aceitáveis de perda de solo estar voltada para a produção agrícola, a metodologia utilizada no presente estudo, aplicando-se a EUPS por meio de técnicas de geoprocessamento, mostrou-se rápida e adequada.

Os resultados obtidos, com a indicação de que as áreas de maior risco de erosão estão localizadas próximas aos cursos d'água e nascentes, explicam a perda de alguns córregos, nascentes e o fato de quase todos os mananciais estarem assoreados. Este assoreamento pode ser verificado na Figura 26, em que a coloração do rio Mogi-Guaçu na Imagem de Satélite Landsat 7 - Sensor $\operatorname{ETM}^{+}$(2001), Bandas 3, 4 e 5, apresenta resposta espectral semelhante à de solo exposto (cor avermelhada). 


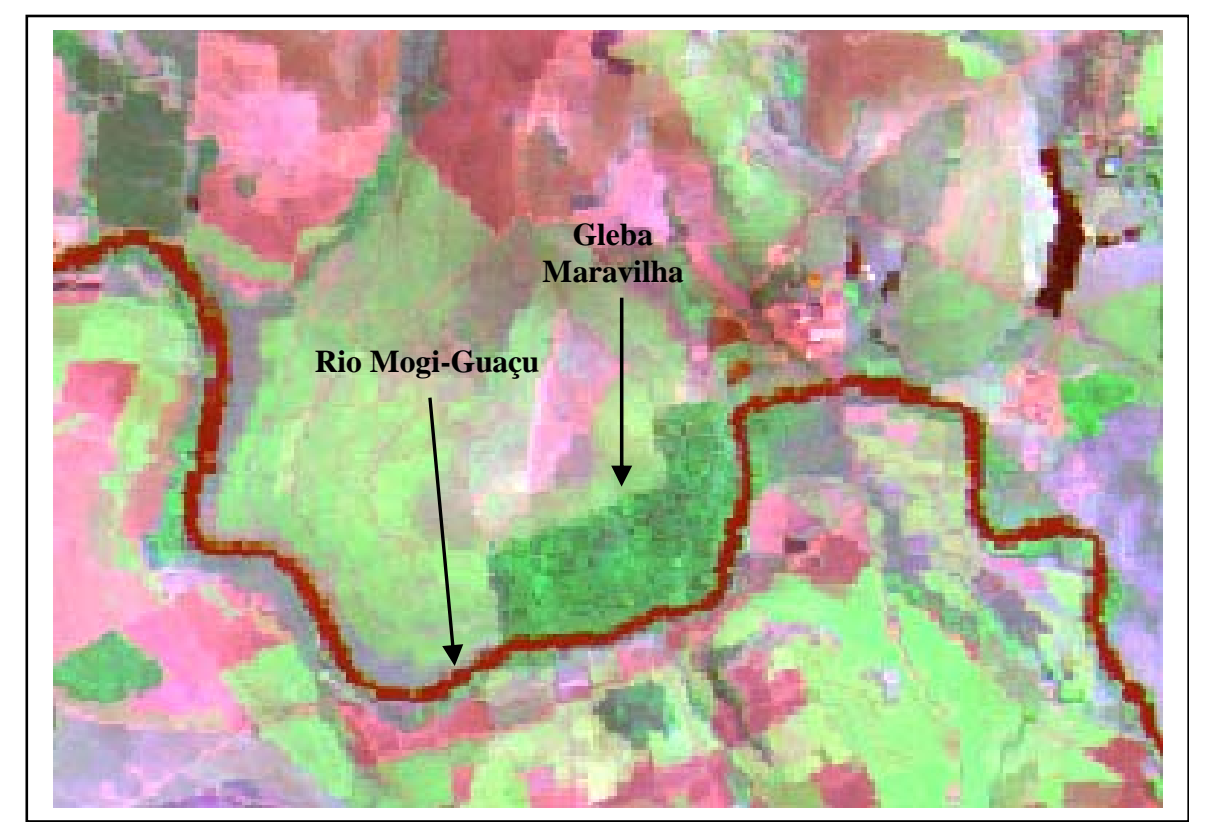

Figura 26 - Detalhe do rio Mogi-Guaçu na imagem de satélite Landsat $7 \mathrm{ETM}^{+}$, composição colorida 3,4,5 (2001), em que o leito do rio aparece com uma coloração avermelhada, correspondente à resposta espectral de solo exposto.

O carreamento de solo e sedimentos em direção aos poucos trechos de mata ciliar remanescentes, colaborando para o aumento do desenvolvimento de espécies invasoras, bem como a perda qualitativa e quantitativa dos recursos hídricos na área de estudo, são decorrentes principalmente do descaso com a conservação do solo e/ou a aplicação de técnicas agrícolas inadequadas, como o mau dimensionamento dos terraços e o plantio de culturas temporárias em solos suscetíveis à erosão ou em áreas com declive acentuado. Estas são algumas das práticas inaceitáveis para o entorno de uma unidade de conservação e contrárias aos objetivos da conservação ambiental.

A indicação das áreas de maior risco de ocorrência de erosão também foi importante para orientar as propostas de alteração do atual uso e ocupação das terras e auxiliar na escolha das áreas para a futura interligação das glebas do PEV e para a proteção dos recursos naturais na região de estudo. 
O fato das áreas de maior risco potencial de erosão estarem próximas as nascentes e cursos d'água, a implantação de corredores ripários incorporando estas áreas, pode ser uma estratégia importante não apenas para a interligação das glebas do PEV, mas também para proteger os mananciais e corpos d'água, minimizando processos de assoreamento e possíveis ocorrências de contaminação pelo carreamento e lixiviação de fertilizantes e defensivos agrícolas.

\subsection{Propostas de interligação e conservação das glebas do PEV}

\subsubsection{Primeira Etapa}

A proposta de interligação das glebas por meio do cumprimento da lelgislação ambiental está apresentada na Figura 27. 


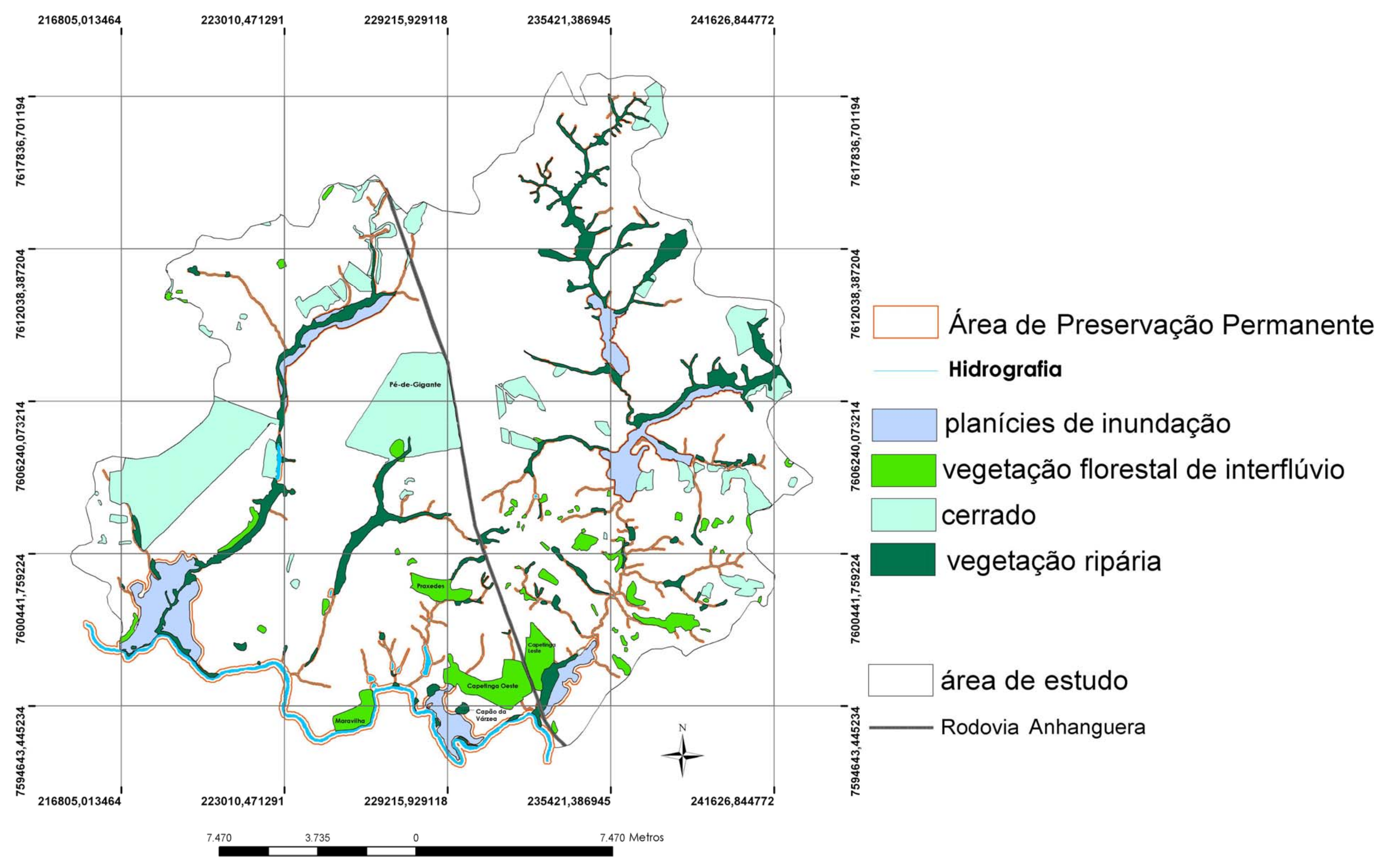

Figura 27 - Etapa 1 - Interligação das glebas do PEV, considerando a legislação ambiental. 
A análise da Figura 27 indica que as glebas do PEV praticamente se interligam pelas áreas de preservação permanente dos corpos d'água (exceção para a gleba Capetinga Leste, que está separada das demais pela rodovia Anhanguera). Porém, devido ao fato da maioria destas APPs estarem em situação irregular, ocupadas por atividades agropecuárias ou com a vegetação ripária degradada e tomadas por gramíneas exóticas, é necessária a recuperação destas áreas. Esta recuperação pode ser realizada por meio do reflorestamento com espécies arbóreas nativas da região ou deixando-se que ocorra a regeneração natural em locais com este potencial, como áreas abandonadas e com banco de sementes (fragmentos florestais nativos próximos).

A área a ser recuperada, estimada por meio da análise da imagem de satélite IKONOS, é de 227 ha. O custo de implantação (rendimentos operacionais e implantação de florestas nativas, adotando-se a metodologia desenvolvida pelo Departamento de Ciências Florestais da Escola Superior de Agricultura "Luiz de Queiroz", da Universidade de São Paulo), é de R\$ 5.040,00 por hectare (cinco mil e quarenta reais) (USP, 2000) ou US\$1.500,00 (cotação do dollar americano em 07/01/2003).

Seria possível reduzir os custos de implantação de florestas nativas, realizando plantio misto - com espécies nativas plantadas entremeadas com culturas agrícolas - para que os proprietários pudessem utilizar esse espaço por dois ou três anos, até que a mata se fechasse. Porém, o fato da nossa legislação não permitir o uso agrícola das APPs dos corpos d'água, considerouse para as análises preliminares de custos de implantação de reflorestamentos com espécies nativas, o valor de R\$5.040,00/ha (US\$1.500,00/ha). Assim, o custo total estimado para recuperar as áreas de preservação permanente dos corpos d'água que "interligam" as glebas do PEV é de R $\$ 1.144 .080,00$ (Um milhão, cento e quarenta e quatro mil e oitenta reais) (US\$ 340.500,00).

Analisando-se os locais onde as áreas de preservação permamente estão em desacordo com a legislação ambiental, dois cursos d'água merecem 
destaque e devem ser emergencialmente recuperados, que são os dois afluentes do rio Mogi-Guaçú que passavam por entre a gleba Capetinga Leste, indicados com setas sobre a imagem de satélite Ikonos na Figura 28.

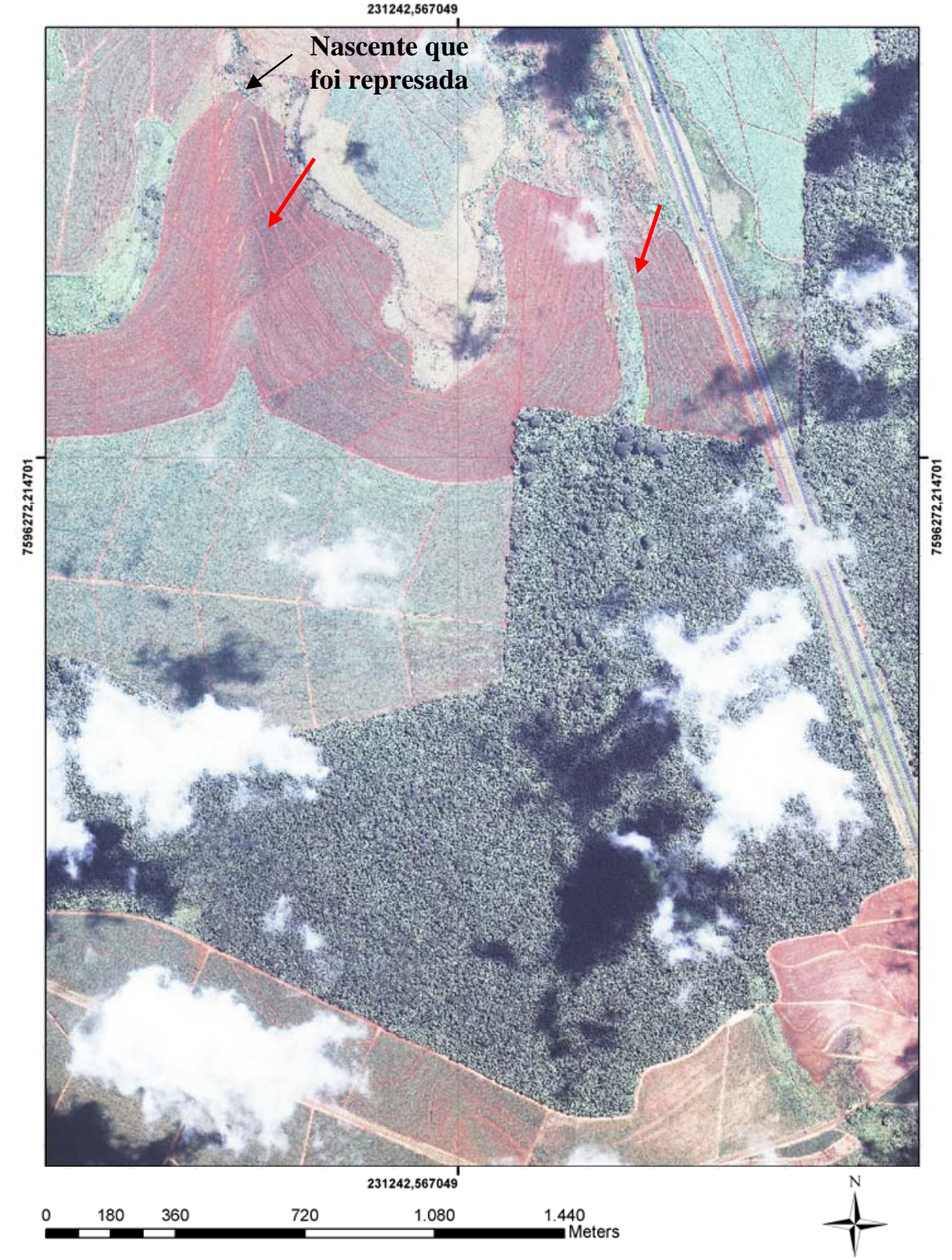

Figura 28 - Cursos d'água prioritários para a recuperação da vegetação nativa indicados com setas na imagem de satélite Ikonos (2002). O curso d'água à esquerda teve a sua nascente represada e, à direita, o córrego que foi isolado com cerca. 
No córrego mais próximo à rodovia Anhanguera (seta à direita), que se encontra assoreado, sem mata ciliar, com invasão de capim e isolado com cerca de arame, servindo de área de pastagem, propõem-se para a sua recuperação:

a) retirar o gado e a cerca de arame;

b) controlar o capim e recuperar o antigo leito do córrego, mediante o seu desassoreamento (observando-se que o material ou a terra e capim retirados não devem ser depositados dentro da faixa de preservação permanente de 30 metros);

c) reflorestar com espécies arbóreas nativas de ocorrência nas matas ciliares da região. A extensão da área sem vegetação nativa e/ou invadida com capim exótico é de aproximadamente 1.700 metros. Desta forma, a área de preservação permanente a ser reflorestada, de acordo com o Código Florestal, é de 10,2 ha. Seriam necessárias 17.000 mudas de árvores nativas (adotandose espaçamento padrão de plantio de $3 \times 2$ metros). Neste caso, o custo aproximado de recuperação deste córrego é de $\mathrm{R} \$ 51.408,00$ (cinqüenta e um mil, quatrocentos e oito reais) (US\$15.300,00).

d) redimensionar ou reformar os terraços nas vertentes, objetivando minimizar os processos de erosão e assoreamento que ocorrem, principalmente após as reformas dos talhões de cana-de-açúcar.

No córrego que teve a sua nascente represada, as principais medidas são:

a) retirar a cultura de cana-de-açúcar e pastagem, e recuperar o antigo leito do córrego;

b) interromper o represamento, permitindo que a água volte a percorrer o leito recuperado até o interior da gleba, ou seja, o retorno à situação original, antes do represamento, conforme a hidrografia representada no mapa do IBGE (IBGE, 1971); 
c) reflorestar com espécies arbóreas nativas de ocorrência na região, nas faixas de 30 metros de cada lado do córrego, totalizando uma área aproximada a ser reflorestada de 12 ha, plantio de 20.000 mudas (espaçamento de $3 \times 2$ metros). O custo aproximado para restaurar este córrego é de $\mathrm{R} \$ 60.480,00$ (sessenta mil quatrocentos e oitenta reais) (US\$18.000,00).

Informações obtidas em fotografias aéreas pertencentes ao arquivo do Parque Estadual de Vassununga (vôo realizado em 1962, pelo Instituto Agronômico de Campinas/Secretaria da Agricultura, escala 1:25:000; e vôos de 1963 e 1965, escala 1:60.000, realizados pelo Exército Brasileiro, segundo informações do IPT - Instituto de Pesquisas Tecnológicas, que detém fotos dos vôos em seu acervo), mostram que o desmatamento da vegetação ribeirinha e a destruição destes corpos d'água, incluindo o represamento de uma das nascentes, foram realizados provavelmente entre as décadas de 60 e 70 .

Esta primeira etapa de interligação das glebas do PEV considera propostas básicas da conservação, pois se trata do cumprimento da legislação ambiental vigente. Porém, para a sua efetiva aplicação, são necessárias políticas públicas que visem capacitar os órgãos ambientais de licenciamento e fiscalização ambiental, bem como conscientizar os produtores rurais e industriais e programas de incentivo para a conservação de suas áreas ambientais e de preservação permanente. Pires (1999) lista algumas abordagens de manejo para a manutenção da biodiversidade de fragmentos de áreas naturais, entre as quais: a implantação de programas de educação ambiental no meio rural e urbano para explicar a importância da manutenção da diversidade biológica e para minimizar práticas de fogo, caça e coleta; a capacitação e/ou treinamento pessoal da Polícia Florestal, Corpo de Bombeiros, etc, e o fomento para a implantação de florestas com essências nativas, por meio de incentivos fiscais e extensão rural aos proprietários. 


\subsubsection{Segunda Etapa}

A figura 29 apresenta o mapa temático das propostas de interligação das glebas do PEV por meio de implantação de corredores e pontos de ligação e a incorporação de áreas às glebas florestais do PEV (Capetingas Leste e Oeste, Maravilha, Praxedes e Capão da Várzea), além da indicação dos locais para a implantação de dispositivos para proteção à fauna nas proximidades de rodovias. 


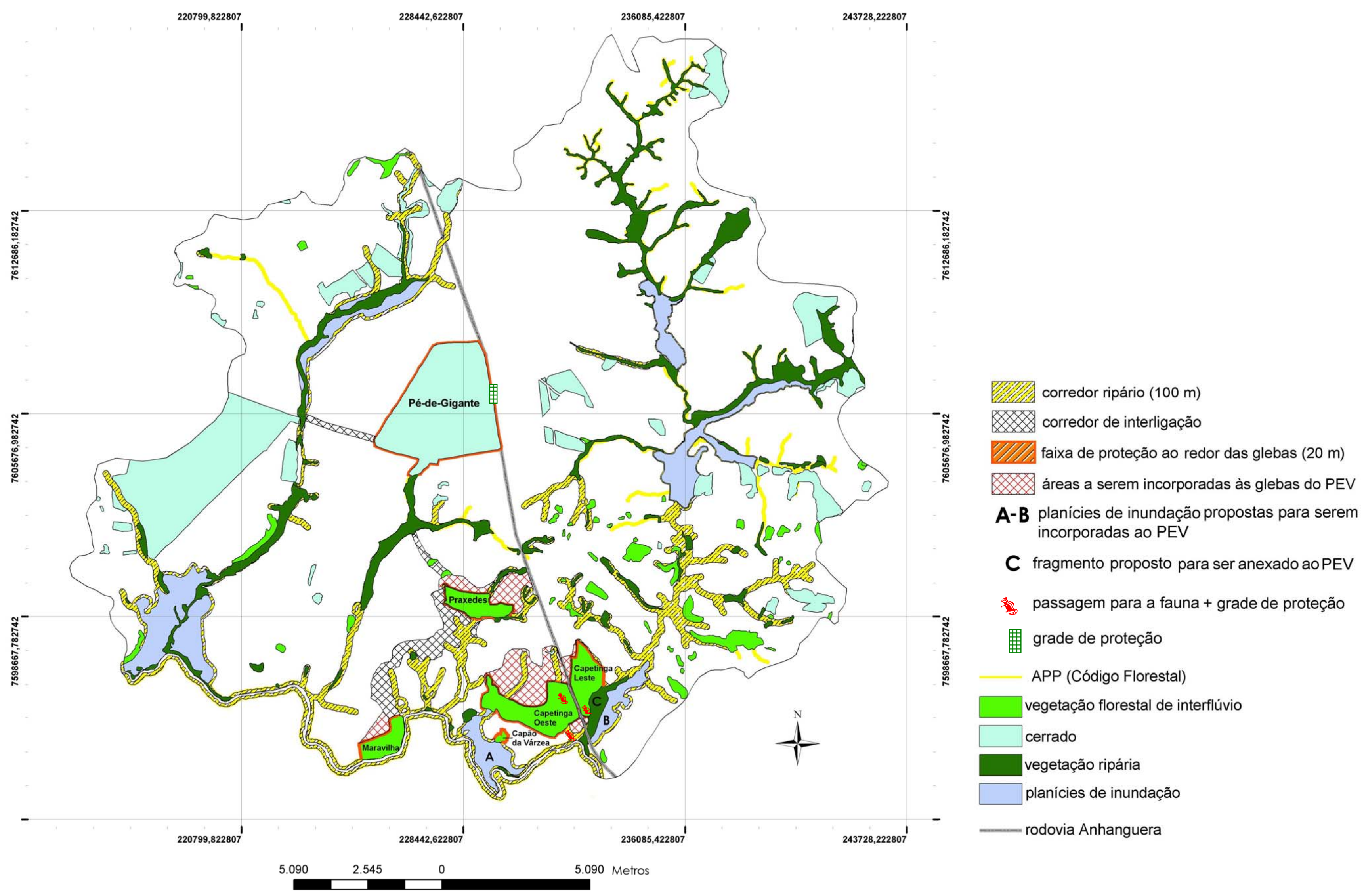

Figura 29 - Etapa 2 com propostas de interligação das glebas por corredores e aumento de área das glebas florestais do PEV. 
Nesta segunda etapa, foi proposta a criação de quatro corredores de interligação entre as glebas:

a) Corredores Ripários:

São os corredores de vegetação ribeirinha, com largura mínima de $100 \mathrm{~m}$ de cada lado das margens, a serem implantados em determinados cursos d'água.

A proposta de implantação dos corredores ripários, com largura superior às estabelecidas pelo Código Florestal, considerou o papel que estes exercem, tanto no fluxo gênico, como na proteção aos recursos hídricos. Diversos autores consideram os ecossistemas ribeirinhos como corredores naturais, servindo de habitat para determinadas espécies da fauna silvestre e de refúgio e área de dispersão para algumas espécies da flora e fauna, bem como por contribuírem na proteção dos recursos hídricos (Noss, 1992; Machtans et al., 1996; Naiman et al., 1997; Johnson et al., 1999; Rodrigues \& Leitão-Filho, 2000). A integridade dos corredores ripários possui crucial importância na prevenção da erosão do solo e na manutenção da qualidade da água (Collinge, 1996; Machtans, 1996; Johnson et al., 1999; Rodrigues \& Leitão-Filho, 2000).

A importância da vegetação ribeirinha ou ripária na área de estudo para diversas espécies de mamíferos foi observada por Jorge (1999). Segundo a autora, a maior riqueza e segunda maior diversidade encontrada na gleba de cerrado (Pé-de-Gigante) e proximidades, foram observadas na floresta ripária. Marinho-Filho \& Castal (2000) também indicam a importância deste ecossitema para várias espécies de mamíferos do cerrado. De acordo com os autores, 4/5 da fauna de mamíferos do cerrado mantém alguma relação com as matas de galeria devido à sua alta complexidade estrutural, permitindo a manutenção de altos níveis de diversidade biológica. 
Segundo Zakia (2002), há autores que consideram não haver métodos definitivos para o estabelecimento da largura mínima da faixa ripária e que possibilite uma proteção satisfatória ao curso d'água. A autora ressalta, portanto, o parecer de Clinnick $(1985)^{3}$, para as condições de áreas florestais na Austrália: "embora existam grandes variações de critérios e larguras de faixa ciliar utilizados, recomenda-se a largura mínima de 30 metros para a proteção de cursos d'água".

A largura mínima proposta neste estudo considerou os valores médios da influência dos efeitos de borda encontrados na literatura para florestas tropicais e/ou na região de estudo (média de 30 a 60 metros). Corredores ripários de no mínimo $100 \mathrm{~m}$ de largura podem propiciar uma faixa de corredor com menor influência dos efeitos de borda. Algumas simulações realizadas neste estudo, com corredores ripários mais largos (200 m, por exemplo), indicaram um aumento excessivo no custo e complexidade na implantação, uma vez que a área agrícola a ser atingida seria maior, incluindo algumas sedes de propriedades e usina.

Os locais escolhidos (Figura 30) para a implantação de corredor ripário com 100 m de cada lado da margem do corpo d'água, são: (i) a rede de drenagem entre as seis glebas do PEV, (ii) os corpos d'água presentes na face leste da rodovia Anhangüera, próximo à gleba Capetinga Leste e (iii) mananciais próximos à rodovia Anhanguera.

A área total estimada para a implantação do corredor ripário de $100 \mathrm{~m}$ é de 2.603 ha. Os locais de implantação que necessitam ser recuperados (reflorestados) são aproximados, pelo fato de terem sido calculados sobre o Mapa de Uso das Terras (Shida, 2000. Modificado), com escala 1:50.000 e resolução espacial de 30 metros. Portanto, a quantificação da área a ser recuperada para a implantação dos corredores ripários não é precisa. O custo

${ }^{3}$ CLINNICK,P.F., 1985. Buffer strip management in forest operations: a review. Australian Forestry, 48 (1): 34-45. 
estimado para implantar os corredores ripários de 100 metros na área de estudo é de $R \$ 13.119 .120,00$ (Treze milhões, cento e dezenove mil e cento e vinte reais) (US\$3.904.500,00).

Destaca-se que, parte da área dos corredores ripários, já deveria estar recuperada (com a presença de vegetação nativa), por serem áreas de preservação, previstas no Código Florestal.

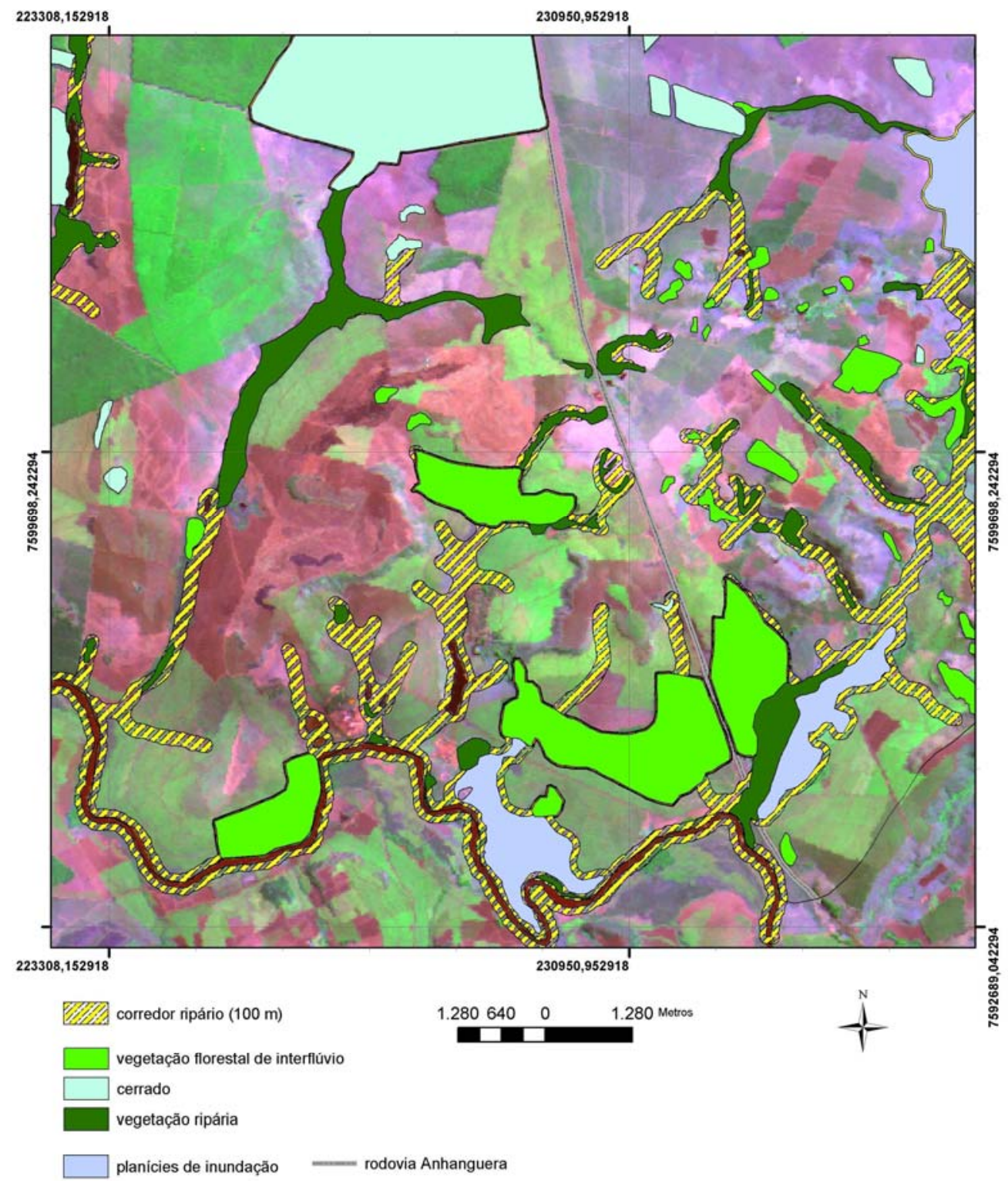

Figura 30 - Indicação na imagem de satélite Landsat $7 \mathrm{ETM}^{+}$(2001) dos principais locais para a implantação de corredores ripários de largura de $100 \mathrm{~m}$ nas margens dos corpos d'água. 
b) Corredor entre a gleba Praxedes e a mata ciliar do córrego da Água Santa:

A área total proposta para este corredor (Figura 31) é de 32,9 ha, com largura variada de 160 a $300 \mathrm{~m}$ e custo estimado de implantação de $\mathrm{R} \$$ 165.816,00 (Cento e sessenta e cinco mil, oitocentos e dezesseis reais) (US\$ 49.350,00).

O objetivo deste corredor é interligar as glebas Pé-de-Gigante e Praxedes, por meio da implantação de um corredor florestal formado por espécies arbóreas nativas, a partir da gleba Praxedes até a mata ciliar do córrego da Água Santa, que se liga, por sua vez, à gleba Pé-de-Gigante. Apesar de possuírem fisionomias de vegetação diferentes (cerrado, floresta estacional semidecídua e mata ribeirinha), o fluxo da fauna silvestre entre as glebas Praxedes e Pé-de-Gigante, passando inclusive por talhões de cana-de-açúcar, ocorre naturalmente, principalmente com algumas espécies de mamíferos de pequeno, médio e grande porte (Ribeiro, H.J. com. pess. e observações de pegadas em campo). Este hábito de locomoção de várias espécies da fauna por entre fisionomias florestais diferentes é comum em regiões do domínio morfoclimático do Cerrado além do cerrado propriamente dito - como a floresta estacional, a floresta ripária (ou ribeirinha), campo úmido e campo rupestre (Coutinho, 1992).

Informações relevantes sobre os padrões biogeográficos de organismos de florestas de ocorrência em regiões de cerrado são encontradas em Silva \& Bates (2002): (i) $56,3 \%$ das espécies de mamíferos não-voadores habitam também florestas; (ii) a maioria das espécies de pássaros $(51,8 \%)$ é dependente de vários habitats florestais; (iii) $82,6 \%$ das espécies de aves de cerrado requerem, em determinado grau, florestas; (iv) em geral, estes dados suportam a hipótese de que as florestas de galeria e florestas estacionais, o qual ocupam menos de $20 \%$ do cerrado, são necessárias e responsáveis por parte significativa da biodiversidade regional. Marinho-Filho \& Castal (2000) revelam que, apesar da pequena representação espacial das florestas de 
galeria no conjunto das formações do domínio do cerrado, que é de apenas 5\%, oito espécies endêmicas ocorrem nesta formação. Isto corresponde à metade do total das espécies endêmicas da região do Cerrado; além de 58 espécies de mamíferos ameaçados de extinção, entre as quais, o lobo guará - Chrysocyon brachyurus e a onça parda - Puma concolor.

Jorge (1999), avaliando o potencial faunístico da gleba Pé-de-Gigante, com base na análise de habitats, verificou a importância da heterogeneidade do habitat, uma vez que seus resultados confirmam a distribuição diferenciada de pequenos mamíferos na paisagem, variando em composição específica e abundância nas manchas de habitats distintos, principalmente em virtude da cobertura vegetal e da presença de água.

É importante destacar que é significativa a ocorrência de animais que morrem carbonizados no período da colheita da cana-de-açúcar por meio da queima dos talhões (Jorge, 1999; Pires et al., 2000). A implantação do corredor ilustrado na Figura 31 asseguraria um transporte mais seguro para a fauna da região, servindo como refúgio e provável habitat para determinadas espécies. 


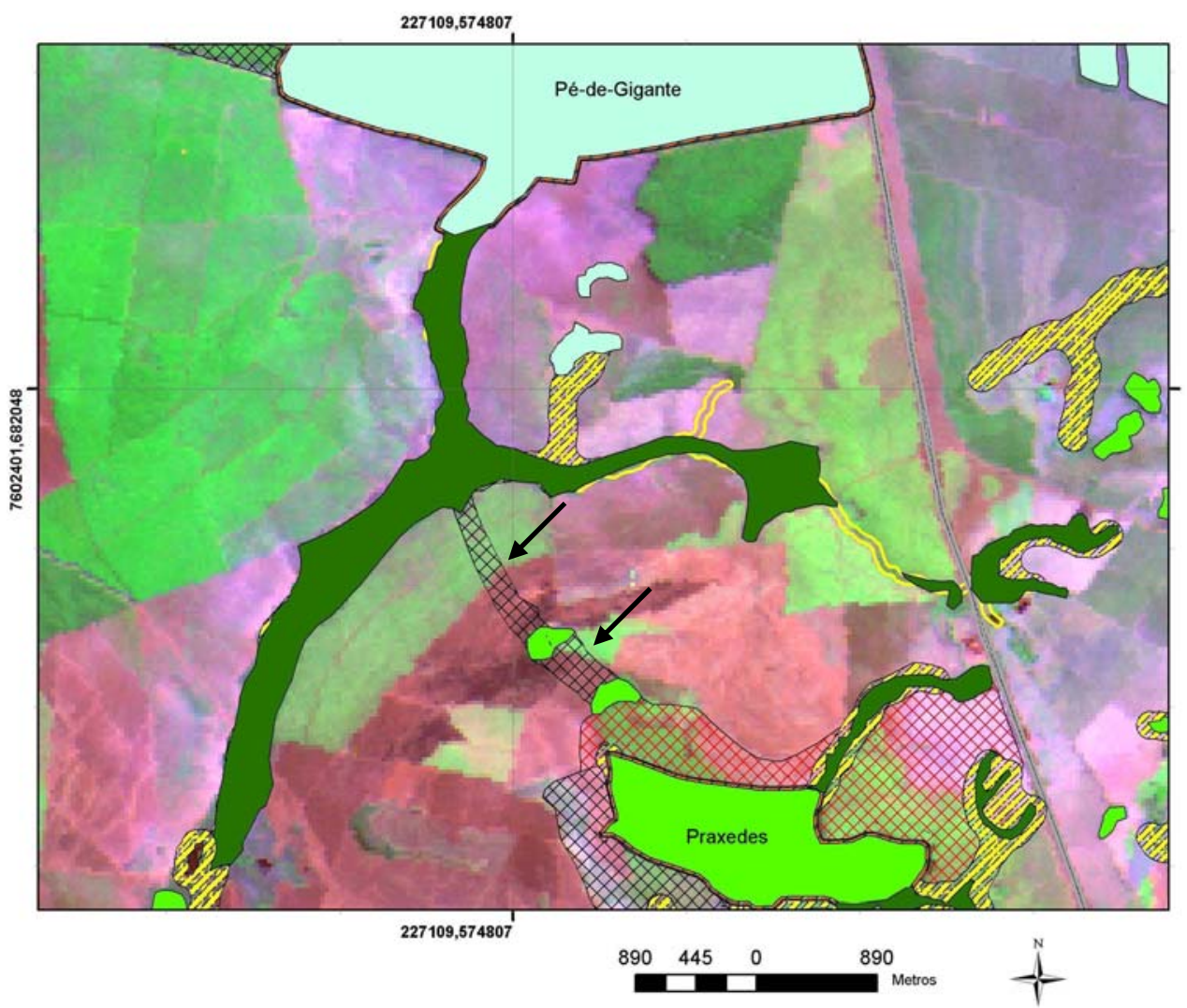

corredor de interligação (gleba Praxedes - córrego da Água Santa)

$X$ áreas a serem incorporadas às glebas

vegetaçăo florestal de interflúvio cerrado

- rodovia Anhanguera

Figura 31 - As setas indicam a localização na imagem de satélite Landsat 7 $\mathrm{ETM}^{+}$(2001) do corredor que interliga a gleba Praxedes com a mata ciliar do córrego da Água Santa. 
c) Corredor entre as glebas Praxedes e Maravilha:

A implantação deste corredor irá interligar duas glebas de floresta estacional semidecídua e outros pequenos fragmentos, além da proximidade com o corredor ripário (Figura 32). A importância deste corredor, além de promover a interligação das glebas, com o aumento potencial do fluxo gênico, relaciona-se, também, à proteção de mananciais, interligando o corredor às nascentes que existem no local; à proteção contra processos erosivos, uma vez que o corredor engloba a encosta de uma serra (Serrote da Saudade) e algumas áreas de maior risco de erosão analisadas no mapa de risco potencial de erosão (item 4.1.4).

A área total deste corredor é de cerca de 334 ha. Portanto, é necessário reflorestar apenas parte da área (excluindo-se a serra Serrote da Saudade, que apresenta afloramento de rocha em alguns locais). Neste caso, a área a ser recuperada mediante o reflorestamento com espécies arbóreas de floresta estacional semidecídua é de aproximadamente 246 ha e com custo estimado de implantação de $R \$ 1.209 .600,00$ (Um milhão, duzentos e novel mil e seiscentos reais) (US\$ $369.000,00)$. 


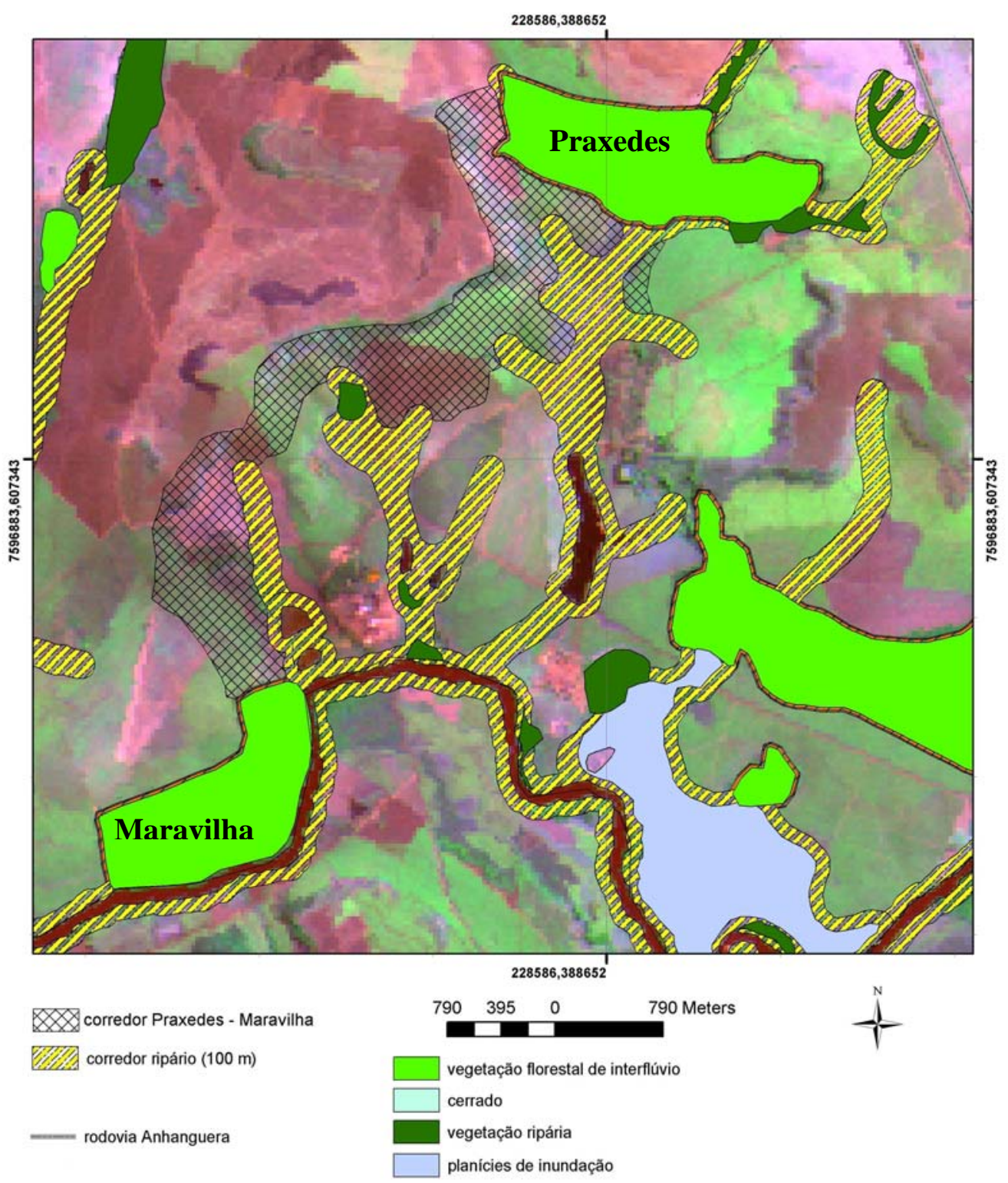

Figura 32 - Localização do corredor Praxedes / Maravilha, sobre a imagem de satélite Landsat $7 \mathrm{ETM}^{+}, 2001$. 
d) Corredor e llhas de Biodiversidade entre a gleba Pé-de-Gigante e um fragmento de cerrado pertencente à Estação Experimental de Luiz Antônio.

O parâmetro considerado para a proposta de implantação deste corredor foi a de interligar os dois maiores fragmentos de cerrado presentes na área de estudo, ambos sob a administração do Instituto Florestal da Secretaria Estadual do Meio Ambiente e propiciar um corredor com as funções de refúgio, condutor e habitat para determinadas espécies da fauna silvestre.

A área para a implantação deste corredor possui, no momento, o plantio comercial de Eucalyptus grandis (Figura 33). As áreas de plantio de eucalipto na região de estudo servem de condutor e refúgio para várias espécies de mamíferos (Jorge, 1999; Munari et al., 2001); mas, para a avifauna, o eucaliptal tem exercido a função de barreira (P.F. Develey. com. pessoal). Estudos realizados nestas áreas de monocultura de eucalipto indicam a importância de se manter um sub-bosque de vegetação nativa arbórea e arbustiva, a fim de fornecer recursos alimentares para a fauna local que transita por estas florestas e aumentar a complexidade estrutural da vegetação. Outra opção seria o manejo do corte do eucalipto, seguindo um cronograma de plantio e corte, deixando-se sempre corredores de árvores (e sub-bosque) para servirem de comunicação entre os talhões não cortados (Pivello, 1997 in Jorge, 1999).

Diante desta situação, a implantação de um corredor composto por vegetação nativa teria várias funções, como a de refúgio, principalmente para mamíferos, e a de habitat e condutor para muitas espécies, incluindo a avifauna. Especificamente em relação à avifauna, propõem-se, além de um corredor contínuo, a implantação de pequenas "ilhas de biodiversidade" (ou ilhas de regeneração) por entre os talhões de eucalipto (Figura 33).

Considerou-se, também, para a implantação deste corredor, a facilidade e o sucesso de implantação. No eucaliptal não haveria a necessidade de reflorestar a área, uma vez que se observa, na região de estudo, a rápida regeneração do sub-bosque, com o desenvolvimento diversificado de espécies 
arbóreas nativas. Este intenso processo de sucessão secundária no subbosque de talhões de Eucaliptus grandis também foi analisado por Carneiro (2002), no município de Itatinga, região norte do estado de São Paulo. O autor considera viável a condução da regeneração com o objetivo de restaurar a vegetação natural.

A largura mínima proposta para este corredor é de 200 m, com 2,4 km de comprimento e totalizando uma área de 50 ha.

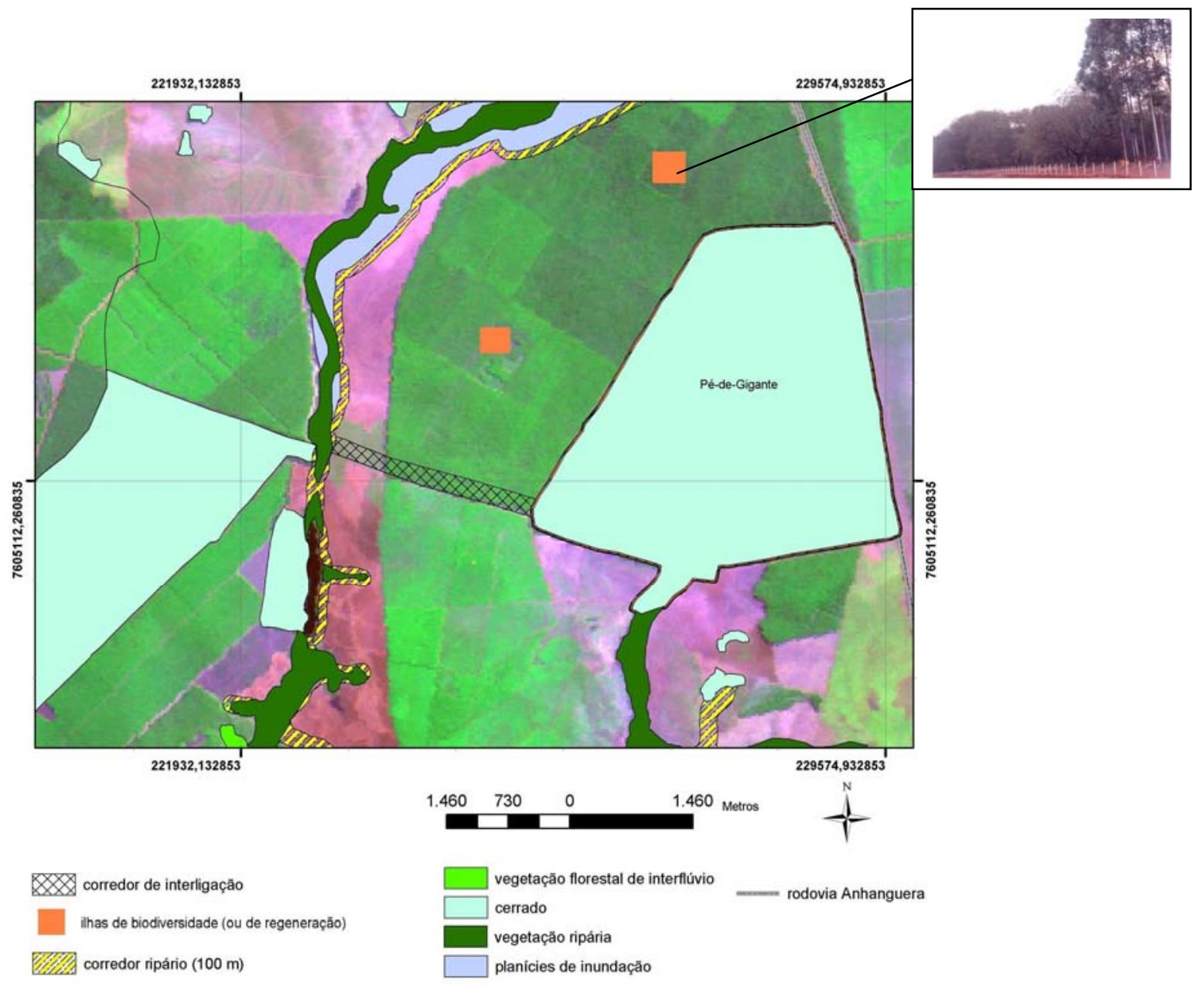

Figura 33 - Localização do corredor Pé-de-Gigante - Estação Experimental de Luiz Antônio, sobre imagem de satélite Landsat $7 \mathrm{ETM}^{+}, 2001$ e algumas ilhas de biodiversidade. À direita, foto ilustrativa exemplificando uma ilha de biodiversidade por entre talhões de eucalipto. 
Além de corredores de interligação, realizou-se proposta para o aumento das glebas florestais do PEV e implantação de faixas de proteção (zonas tampão) nas suas bordas.

Interligar as glebas do PEV por corredores e pontos de ligação, desconsiderando medidas para a conservação das mesmas, seria de pouca eficácia para a conservação do Parque, uma vez que estão sob influência dos efeitos de borda.

De acordo com Collinge (1996), a influência dos tipos de atividades humanas do entorno sobre a integridade ecológica das áreas destinadas à conservação e o grau de heterogeneidade dos tipos de habitat, podem influenciar significativamente no fluxo de nutrientes e sedimentos, bem como na persistência de espécies de plantas e animais.

Rodrigues et al. (2001), propuseram a implantação de "cinturões de proteção" ao redor de fragmentos florestais remanescentes inseridos em 62 propriedades agrícolas da Cia. Açucareira Vale do Rosário, em áreas de plantio de cana-de-açúcar. Os "cinturões verdes" têm como objetivo retirar os fatores de degradação nas bordas destes fragmentos, principalmente os riscos de ocorrência de incêndios durante o período de colheita da cana-de-açúcar. Estas faixas de proteção consistem na implantação de um aceiro de dez metros ao redor do fragmento e uma faixa de $100 \mathrm{~m}$, denominada de "cinturão de proteção", em que a cana-de-açúcar deve ser colhida crua.

A colheita da cana-de-açúcar, utilizando-se fogo em áreas próximas a fragmentos de vegetação nativa, é uma ameaça à biodiversidade, não apenas pelo risco direto de incêndio no fragmento, mas também pelo aumento dos efeitos de borda, causados pelo excessivo calor que atinge essas áreas e, provavelmente, eliminam espécies locais (Pires, 1999; R. R. Rodrigues, com. pess.; H. J. Ribeiro, com. pess.).

No presente estudo, as propostas para eliminar ou reduzir os fatores de degradação das bordas, além da eliminação do uso de fogo para a colheita da 
cana-de-açúcar e manejo do pasto e a manutenção de aceiros com largura mínima de $10 \mathrm{~m}$ (mantidos limpos, principalmente no período da estiagem), são:

a) Faixas de proteção de $20 \mathrm{~m}$ ao longo de todo o perímetro das glebas do $\mathrm{PEV}$, reflorestadas com espécies arbóreas nativas de rápido crescimento $\mathrm{e}$ fuste liso, para minimizar a proliferação de cipós, lianas e gramíneas exóticas. Esta largura proposta, de $20 \mathrm{~m}$, baseia-se na Informação Técnica AT-DRPE 001/96, desenvolvida por técnicos do Instituto Florestal. Na face norte dos fragmentos, estas faixas de proteção podem ser maiores, de acordo com as recomendações conservacionistas de Rodrigues (1998). Este autor sugere que, em fragmentos florestais pequenos, os esforços de conservação devem se concentrar nas bordas voltadas para o norte, pelo fato de, em regiões tropicais, os fatores abióticos serem mais intensos nesta face. O desenvolvimento de um "cordão verde" de proteção ao redor das glebas, tem como objetivo absorver os impactos ou fatores de borda (vento, calor, luz), além de promover o sombreamento da borda do fragmento, diminuindo o crescimento das gramíneas exóticas, cipós e lianas.

Com a degradação que ocorre nas bordas das glebas - a incidência de espécies gramíneas exóticas e o desenvolvimento de cipós e lianas, prejudicando o sucesso da regeneração de espécies nativas de crescimento lento - deve-se implantar faixas de proteção e realizar o manejo das espécies invasoras. A área ocupada para a implantação (reflorestamento) das faixas de $20 \mathrm{~m}$ é de 74,8 ha (descontando-se a área correspondente aos $10 \mathrm{~m}$ de aceiro). Utilizando-se espaçamento de plantio de $3 \times 2 \mathrm{~m}$, serão necessárias cerca de 125.000 mudas de espécies nativas. Este espaçamento de $3 \mathrm{~m}$ entre linhas facilita os procedimentos de controle das espécies invasoras. Após a implantação, estas faixas de proteção podem ser utilizadas como banco genético, mediante a coleta de sementes. 
b) Manejo/controle de espécies invasoras. Além da implantação de um cordão de reflorestamento com espécies arbóreas nativas de rápido crescimento, devese realizar o controle das gramíneas exóticas e o manejo de cipós e lianas. Praticamente inexistem estudos aplicados sobre metodologias para o controle de espécies invasoras, principalmente, para o controle de lianas. Rodrigues et al. (2001) ressaltam que a eliminação destas espécies, sem critérios técnicos, pode levar à perda de parte da biodiversidade do fragmento. Os autores recomendam que, mediante a evidência de crescimento excessivo de algumas espécies de lianas que estejam em desequilíbrio, pode-se propor algum tipo de manejo apenas para estas espécies e com o acompanhamento de profissionais habilitados. Para a eliminação das gramíneas, além do sombreamento com a implantação da faixa de proteção, deve-se realizar roçadas periódicas.

Em relação ao aumento efetivo das glebas florestais, as áreas propostas para serem incorporadas à área total do PEV estão descritas a seguir e ilustradas na Figura 34. 


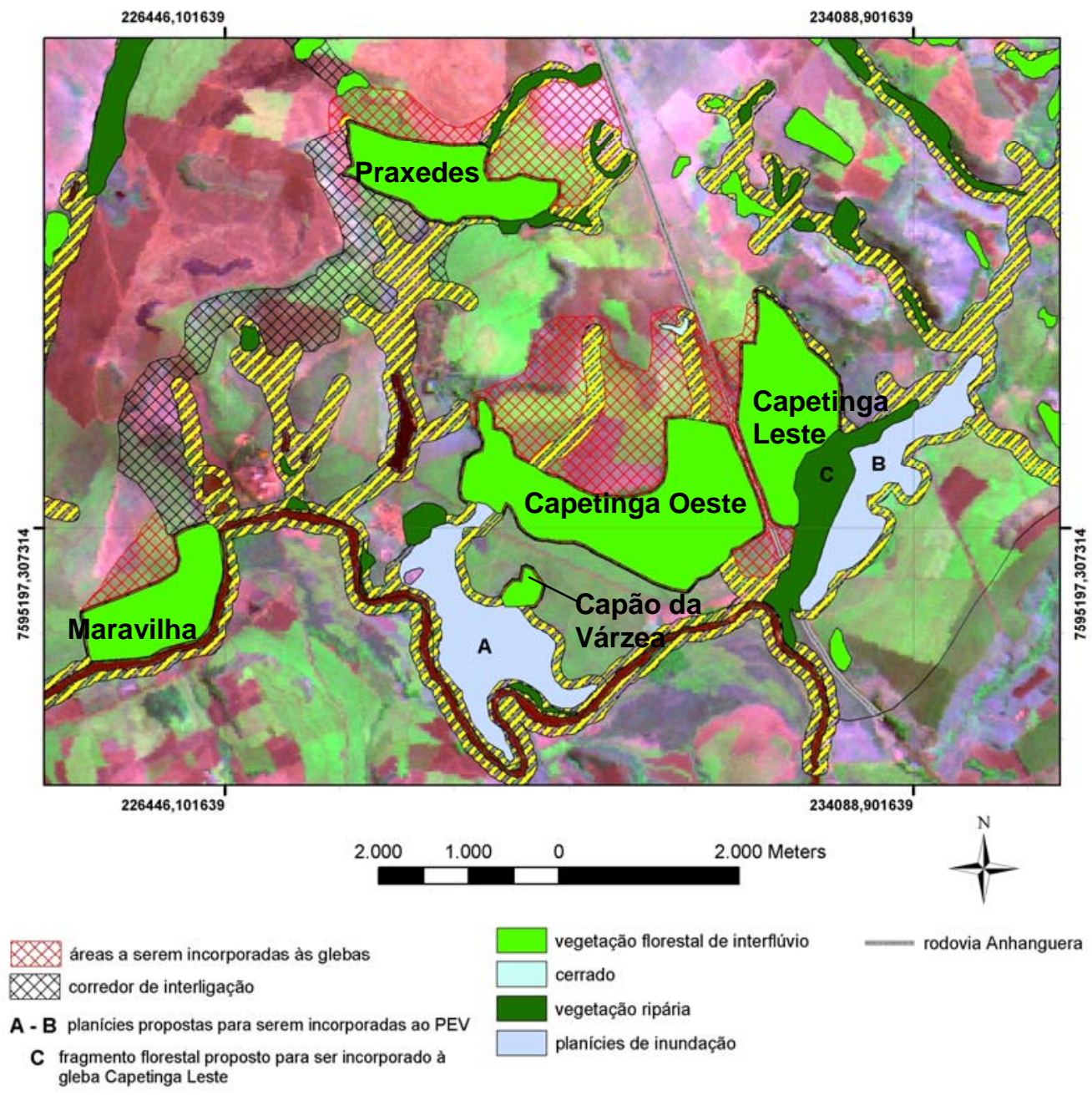

Figura 34 - Localização sobre a imagem de satélite Landsat 7 ETM+, 2001, as áreas propostas para serem incorporadas às glebas do PEV. 
De acordo com a figura 34, as áreas propostas para serem anexadas à área total do PEV são:

- Gleba Praxedes: a área proposta para ser reflorestada e anexada à gleba Praxedes possui 175 ha e localiza-se na face norte da gleba. O aumento de área será maior, se considerarmos o corredor que interliga esta gleba a gleba Maravilha, com aumento efetivo de área, também em sua face sul. A proposta englobou, também, além do formato alongado da gleba e os efeitos de borda, a interligação desta área a pequenos fragmentos florestais remanescentes e a proximidade com corredores ripários, aumentando ainda mais o tamanho efetivo da gleba.

- Glebas Capetingas Leste e Oeste: propõe-se um aumento de área para as glebas Capetinga Leste e Oeste de 563 ha, incluindo a incorporação de um fragmento florestal e uma área de várzea, contiguos à gleba Capetinga Leste, conforme ilustra a Figura 34. A proposta de incorporar a várzea tem o objetivo principal de assegurar a integridade deste ecossistema que, a cada ano, vem sendo destruído por queimadas e pelo avanço do plantio da cana-de-açúcar.

Outra área proposta é o morro próximo à rodovia Anhangüera e que faz divisa com a gleba Capetinga Leste (em sua face Oeste). A ausência de manejo e manutenção desta área torna o local suscetível à ocorrência de incêndios e, também, o fato de parte da área ser íngreme em direção à gleba e sem terraços para conter a erosão acelerada. Além de melhorar o fator de forma destas glebas, estas áreas incorporam pequenos fragmentos remanescentes de floresta estacional semidecídua e as áreas de maior risco potencial de erosão. A incorporação das áreas de risco potencial de erosão e a alteração do uso das terras por meio da restauração da vegetação nativa irão promover a proteção das duas únicas nascentes e cursos d'água que passam pela gleba Capetinga Oeste e a interligação com os corredores ripários. O represamento de uma nascente e a destruição de um dos córregos que abastecia a gleba Capetinga 
Oeste, passou a fazer com que muitos animais (principalmente médios e grandes mamíferos) viessem a passar por entre o canavial, percorrendo quase $2 \mathrm{~km}$ até chegar à nascente represada, como foi observado nos levantamentos de campo, com o registro de inúmeras pegadas e a observação visual de um cervídeo que saiu da gleba, passando por meio dos talhões de cana-de-açúcar, indo em direção à nascente.

As áreas que necessitam ser restauradas para o aumento da extensão das glebas Capetinga Leste e Capetinga Oeste - mediante o reflorestamento com espécies arbóreas nativas - totalizam 334 ha.

\section{- Gleba Capão da Várzea:}

O aumento de área proposto para esta gleba, que possui cerca de 12 ha, é de 180 ha. A área proposta corresponde à planície de inundação do rio MogiGuaçu, delimitada pela carta planialtimétrica do IBGE (IBGE, 1971).

Parte da várzea desta planície foi drenada e vem sendo cultivada (canade-açúcar e pasto). A recuperação desta área promoveria o aumento no tamanho da gleba Capão da Várzea, bem como da gleba Capetinga Oeste, pelo fato desta planície interligar-se também a esta outra gleba (figura 34). A conservação das várzeas existentes no entorno do PEV são fundamentais para manter os inúmeros serviços ambientais que este ecossistema oferece, entre os quais: o controle do regime de vazões dos rios (no caso, o rio Mogi-Guaçu), a manutenção da qualidade da água, área de nidificação e de reprodução de várias espécies da fauna silvestre, entre outros. 
- Gleba Maravilha

Esta gleba também possui um formato bastante alongado e localiza-se em área íngreme, com declividade acentuada em direção ao rio Mogi-Guaçu. Propõem-se a incorporação e restauração de 44 ha na face Norte da gleba, melhorando-se a forma do fragmento e aumento-se o tamanho da gleba na face que recebe uma maior influência dos efeitos de borda, de acordo com as recomendações técnicas de Rodrigues (1998).

A área total proposta para ser incorporada ao Parque Estadual de Vassununga é de aproximadamente 963 ha. Desta área, 553 ha necessitam ser recuperados, mediante o reflorestamento com espécies arbóreas nativas e/ou a condução da regeneração natural (em locais com "banco de sementes" próximos). Para as áreas de várzea, deve-se interromper o uso agropecuário e os drenos devem ser abandonados (sem a limpeza dos mesmos), para que os processos de vazão dessas áreas sejam restaurados.

- Estimativas preliminares dos custos de implantação, mediante o reflorestamento com espécies arbóreas nativas, dos corredores e das áreas propostas para serem incorporadas ao PEV:

Somando-se a área total de corredores - 2.882 ha, com a área de 74,8 ha das faixas de $20 \mathrm{~m}$ de proteção ao redor das glebas e área de 553 ha propostas para o aumento das glebas Maravilha, Capetinga Leste, Capetinga Oeste e Praxedes, a área total que necessita ser reflorestada com espécies arbóreas nativas é de 3.510 ha, com custo de implantação de $\mathrm{R} \$ 17.690 .400,00$ (dezessete milhões, seiscentos e noventa mil e quatrocentos reais) (US\$ 5.265.000,00). Este custo de implantação pode ser reduzido se algumas técnicas forem adotadas e/ou passíveis de implantação como, por exemplo, a 
recuperação de algumas áreas por meio da regeneração natural (principalmente em locais onde há fonte de sementes próximas) ou o plantio misto, com espécies nativas plantadas entremeadas com culturas agrícolas, para que os proprietários possam usar esse espaço por dois ou três anos, até que a mata se feche. Outra opção seria o manejo sustentável destas áreas, após a implantação de alternativas como a exploração sustentável, com a extração de sementes ou produtos medicinais (folhas, óleos, etc).

Este custo total não considera o valor da terra, caso seja necessária a desapropriação, pois não é objeto deste estudo realizar levantamentos detalhados de custos. Porém, se faz importante o registro de algumas alternativas para viabilizar a restauração e implantação das áreas dos corredores e de aumento das glebas do PEV, entre as quais: (i) a desapropriação propriamente dita pelo governo estadual ou federal e posterior recuperação ou restauração dessas áreas por empresas com passivos ambientais, por exemplo, empresas que foram autuadas e precisam cumprir termos de ajuste de conduta; (ii) implantação da reserva legal da usina de açúcar e álcool que circunda as glebas do PEV; (iii) implantação de reservas legais obrigatórias na forma de "condomínio" entre vários proprietários agrícolas da região que não possuem a porcentagem mínima de $20 \%$ de vegetação nativa em suas propriedades ou a negociação com os proprietários das terras para alterar os atuais usos da terra, mediante a implantação de sistemas agroflorestais ou a implantação de florestas de manejo. Para estas últimas propostas, é imprescindível que programas de incentivo aos proprietários sejam implantados, como assistência técnica, isenção de impostos, subsídios, etc. (iv) em relação à recuperação das APPs, mesmo sendo de responsabilidade dos proprietários das terras, poderiam-se firmar convênios, com fundos estaduais ou federais, como o FEHIDRO - Fundo Estadual de Recursos Hídricos e, também, convênios com empresas privadas. 


\subsubsection{Propostas para a matriz:}

As propostas dos itens anteriores, para aumentar o tamanho efetivo das glebas do PEV - com aumento de área e zonas tampão - e a interligação dessas glebas por corredores, estarão comprometidas se determinadas práticas de uso das terras persistirem na região de estudo, como o uso de fogo na colheita da cana-de-açúcar, a prática de empurrar restos de cultura em direção aos fragmentos de vegetação nativa, a falta de conservação e manejo adequado do solo e práticas de pulverizações aéreas de defensivos agrícolas e fertilizantes.

O manejo da matriz também como estratégia para o aumento da conectividade da paisagem, relaciona-se à resistência das unidades da matriz aos fluxos biológicos, ou seja, o grau de permeabilidade da matriz (Collinge, 1996; Metzger 1999).

Para que a interligação das glebas por corredores e pontos de ligação ocorra de fato, é preciso que as atividades ou tipos de uso das terras que coloquem em risco ou são contrárias à conservação dos ecossistemas da região sejam alterados, promovendo uma matriz mais permeável.

As propostas para a matriz indicadas neste estudo são:

a) Transformação da área de estudo (por Lei ou Decreto Estadual), em APA Área de Proteção Ambiental:

Esta iniciativa tem como objetivo promover uma integração entre as atividades produtivas e a conservação ambiental, estabelecendo o uso sustentável dos recursos naturais. Esta categoria de área protegida foi estabelecida pela Lei $n^{\circ} 6.902$, de 27 de abril de 1981, e está voltada para a proteção dos recursos naturais que estejam inseridos em um contexto de ocupação humana.

A criação de uma APA na área de estudo facilitaria ou contribuiria para a adoção ou implantação de muitos dos procedimentos propostos neste estudo. 
b) Elaboração do Plano de Manejo do PEV:

Este Plano de Manejo deve contemplar propostas não apenas para as áreas internas do Parque, como também o seu entorno - as zonas de amortecimento e os corredores de interligação (Lei 9985/2000 - SNUC). Estes locais devem ser delimitados em campo e em planta planimétrica, especificando-se quais as atividades que podem ou não ser desenvolvidas nessas áreas.

Sugere-se que o Plano de Manejo seja desenvolvido junto aos centros de pesquisas, como as universidades de ensino e pesquisa, e também órgãos ambientais federais, estaduais e municipais, com a participação da comunidade (organizações não governamentais, estudantes, proprietários agrícolas e empresários).

c) Ampliação dos Recursos Humanos e Materiais do PEV

Atualmente, o PEV possui um número reduzido de funcionários (sendo apenas dois para a fiscalização de suas seis glebas) e poucos recursos financeiros e materiais. O ideal seria que o quadro de funcionários fosse ampliado, e houvesse a setorização de equipes. Equipes técnicas próprias para a fiscalização, equipe administrativa, equipe técnica de manejo e equipe de educação ambiental, por exemplo. Quanto aos funcionários da fiscalização, estes devem estar munidos e ter acesso a torres de fiscalização, rádios de comunicação, veículos tracionados, motocicletas próprias para estradas rurais, binóculos, estojo de primeiro socorros, GPS e máquinas fotográficas (para eventuais registros da fauna silvestre ou de danos ou impactos ambientais). Pelo menos dois destes funcionários deveriam ter telefones rádios de comunicação ou telefones celulares para casos emergenciais, como a necessidade de contato com o corpo de bombeiros, usinas próximas, etc, durante a ocorrência de incêndios nas proximidades do Parque. É fundamental que todos os funcionários recebam treinamentos específicos para a fiscalização 
e treinamentos técnicos sobre combate a incêndios, atendimentos de primeiros socorros e noções básicas de conservação biológica.

Para o amplo funcionamento de um programa administrativo e de fiscalização para o PEV, são necessários mais recursos financeiros, cabendo ao governo estadual o cumprimento deste papel e incentivando a cooperação/participação do setor privado.

d) Interrupção do uso de fogo na área de estudo para a queima de talhões de cana e áreas de pastagens:

A Portaria IBAMA 94-N/98, a Lei Estadual 10.547/00 e o Decreto Estadual 45869/01 proíbem o uso de fogo para a colheita da cana-de-açúcar numa faixa de 50 metros ao redor de uma unidade de conservação (a partir do aceiro de proteção, que deve possuir largura mínima de dez metros) e 15 metros de cada lado das rodovias. Porém, considerando-se os relatos de pessoas da região sobre a alta incidência de animais que morrem no interior dos talhões, no momento da queima da cana-de-açúcar e a verificação em campo da quase total ausência de aceiros, esta prática coloca em risco a manutenção da biodiversidade regional, além dos aspectos negativos que promovem para a saúde humana.

Em palestra proferida no Centro de Estudos Regionais da Universidade de São Paulo, Campus Ribeirão Preto, em 31 de março de 1992, o Prof. Dr. Antonio Ribeiro Franco, docente do Departamento de Medicina Social da Faculdade de Medicina da USP de Ribeirão Preto, afirmou que, em se tratando da análise dos efeitos da poluição atmosférica provocada pela queimada dos canaviais, o que se tem em vista é a saúde da população. Utilizando dados de internações e altas hospitalares do Centro de Processamento de Dados do Departamento de Medicina Social da USP/Ribeirão Preto, referentes aos anos de 1988 a 1990, cobrindo a área de 21 municípios da região canavieira de Ribeirão Preto, o pesquisador verificou que as doenças do aparelho respiratório tiveram destacada relevância, sendo responsáveis por quase 50 mil internações 
naqueles três anos, num universo de 911.426 habitantes, constando-se, ainda, 2.739 óbitos atribuídos a esse grupo de doenças. $O$ referido pesquisador conclui que "não há dúvidas que durante a época das queimadas dos canaviais há uma piora na qualidade do ar da região" (São Paulo, 2002c).

Estudos realizados por $\mathrm{V}$. Kirchhoff, Instituto Nacional de Pesquisas Espaciais (INPE), demonstram que, em regiões brasileiras que realizam queimadas para o manejo do pasto e para a colheita de culturas, geralmente em períodos de estiagem (maio a meados de setembro), as concentrações de monóxido de carbono (CO) e ozônio (O3) são bem maiores, degradando a qualidade da atmosfera (São Paulo, 2002c).

A queima da cana geralmente é feita em meses com ventos fortes. Observações na região de Ribeirão Preto revelam ser comum que labaredas de fogo sejam levadas pelo vento a distâncias bem superiores de 10 metros, atingindo as bordas ou o interior dos fragmentos. Esta largura mínima de aceiro (10 metros) muitas vezes não impede a propagação do fogo para os fragmentos florestais próximos. Diante do exposto, recomenda-se, para a área de estudo, a colheita mecânica em locais passíveis de mecanização. Em áreas onde a colheita mecânica não for possível, deve ser feito um estudo técnico e sócioeconômico para alterar o atual uso das terras (por culturas perenes, silvicultura ou outros projetos compatíveis com a conservação ambiental, como os projetos voltados ao turismo rural ou ecológico).

A implantação da colheita mecânica em toda a área de estudo pode ser feita gradualmente, seguindo-se cronograma de implantação para não promover na região impactos sociais negativos, decorrentes da substituição da mão-de-obra canavieira. Enquanto não se efetivar a total proibição do uso de fogo na área de estudo, recomendam-se medidas de segurança preventivas, como a implantação de faixas de proteção (já descritas) e a colheita da cana crua nos talhões de cana contíguos às glebas. Rodrigues et al. (2001) recomendaram, para o plano de adequação ambiental de várias propriedades agrícolas na região norte e nordeste do estado de São Paulo, a implantação de 
faixas de 100 metros ao redor dos fragmentos de vegetação nativa, onde a cana-de-açúcar é colhida crua, sem o auxílio de queimadas, além da construção de aceiros com $10 \mathrm{~m}$ de largura.

e) Interrupção das pulverizações aéreas de defensivos agrícolas.

Não há estudos que indiquem os danos diretos e indiretos promovidos nos recursos naturais da região pela pulverização aérea de fertilizantes e defensivos agrícolas. Porém, considerando-se o fato de que muitas espécies (flora e fauna) ainda não foram descobertas ou catologadas e, dentre as espécies identificadas, se desconhecem as possíveis implicações desta prática, infere-se que a realização de aspersão de defensivos agrícolas e fertilizantes no entorno das glebas do PEV ou de qualquer unidade de conservação próxima deve ser interrompida, respeitando-se distâncias inferiores a $10 \mathrm{~km}$. Pires (1999), considera, além dos problemas relativos ao isolamento, as ameaças de eliminação biológica às quais a maioria dos fragmentos estão submetidos, sendo a deriva durante a aplicação de defensivos agrícolas uma das fontes de risco de contaminação e eliminação biológica. O autor ressalta que as áreas naturais possuem uma grande variedade de espécies de invertebrados e vegetais inferiores, que desempenham muitas vezes papel fundamental na cadeia trófica e cuja população pode ser eliminada devido ao contato com estes produtos químicos. Além disto, muitos deles possuem metais pesados e outros produtos sintéticos e/ou naturais cujos efeitos cumulativos foram pouco estudados.

f) Sistema de fiscalização ambiental mais efetivo.

Uma fiscalização ambiental melhor qualificada e com um número adequado de funcionários e mais recursos materiais, certamente poderá coibir os procedimentos verificados em campo, como o uso irregular das APPs, a prática usual de se empurrar restos de culturas em direção às glebas e demais 
fragmentos de vegetação nativa, a caça de animais silvestres, a má conservação do solo, entre outros.

A eficiência desta fiscalização deve ir além do caráter punitivo, procurando-se contemplar, também, a orientação e conscientização ambiental para as comunidades da região (urbana, rural e industrial). Para isto, o corpo técnico e de fiscalização deve receber treinamento quanto aos aspectos ambientais (importância ambiental dos ecossistemas a serem protegidos), tipos e formas eficientes de fiscalização/proteção (com o incentivo da fiscalização educativa e preventiva) e o combate emergencial de incêndios ou acidentes ambientais. As equipes devem estar munidas de equipamentos de suporte adequados, como rádios de comunicação, GPS, máquinas fotográficas e veículos tracionados (com disponibilidade de combustível e assistência mecânica).

g) Planejamento e reforma do atual sistema viário.

Analisando-se as ocorrências de atropelamentos da fauna silvestre na rodovia Anhanguera e vias vicinais da região de estudo (Jorge, 1999; Pires et al., 2000), conclui-se que é fundamental a realização de pesquisas para implantação de túneis, passagens e grades de proteção, estando os locais para a implantação dos mesmos indicados nas Figuras 30 e 35, com exemplos de alguns modelos utilizados em rodovias da Alemanha. Todos os exemplos que ilustram este item foram extraídos do Projeto de Ampliação da Capacidade Rodoviária das Ligações com os Países do Mercosul BR-101 Florianópolis(SC)Osório(RS) (DNER/IME, 2002).

O número de passagens recomendado neste estudo para a rodovia Anhanguera, entre as glebas Capetinga Leste e Oeste é de 02 túneis (com distância entre eles de 500 m) e, na rodovia próxima a gleba Praxedes e Capão da Várzea, 01 túnel. Estes túneis devem estar associados a grade ou rede de proteção, evitando que os animais saiam da gleba diretamente em direção à rodovia, como a ocorrência observada no ano de 1998, em que uma espécie de 
veado (Mazama $\mathrm{sp}$ ) saiu diretamente da gleba Pé-de-Gigante em direção à rodovia e outros relatos de atropelamentos de animais silvestres (Ribeiro, H.J. com.pess.).

A Figura 35 ilustra alguns exemplos de dispositivos de proteção que poderiam ser utilizados.

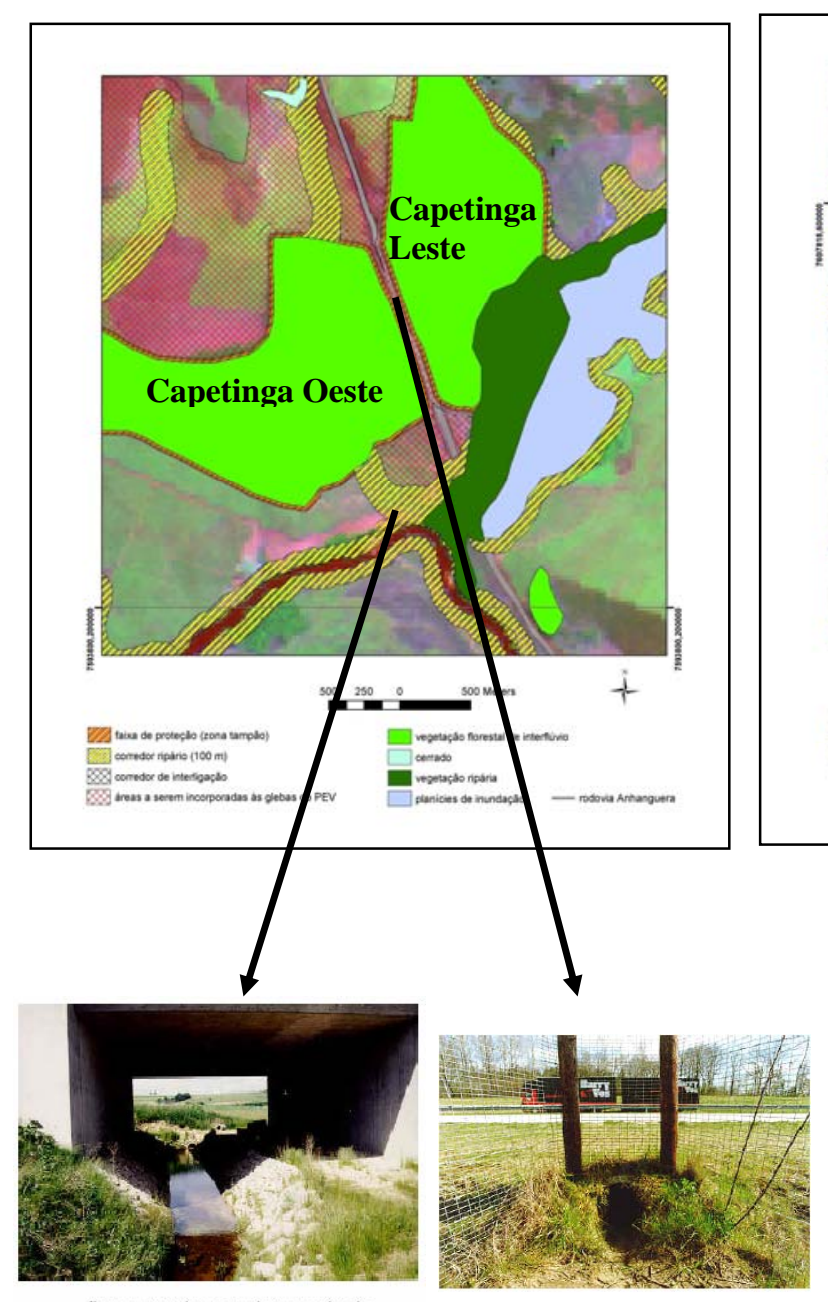

Passagem mista para àgua e animais

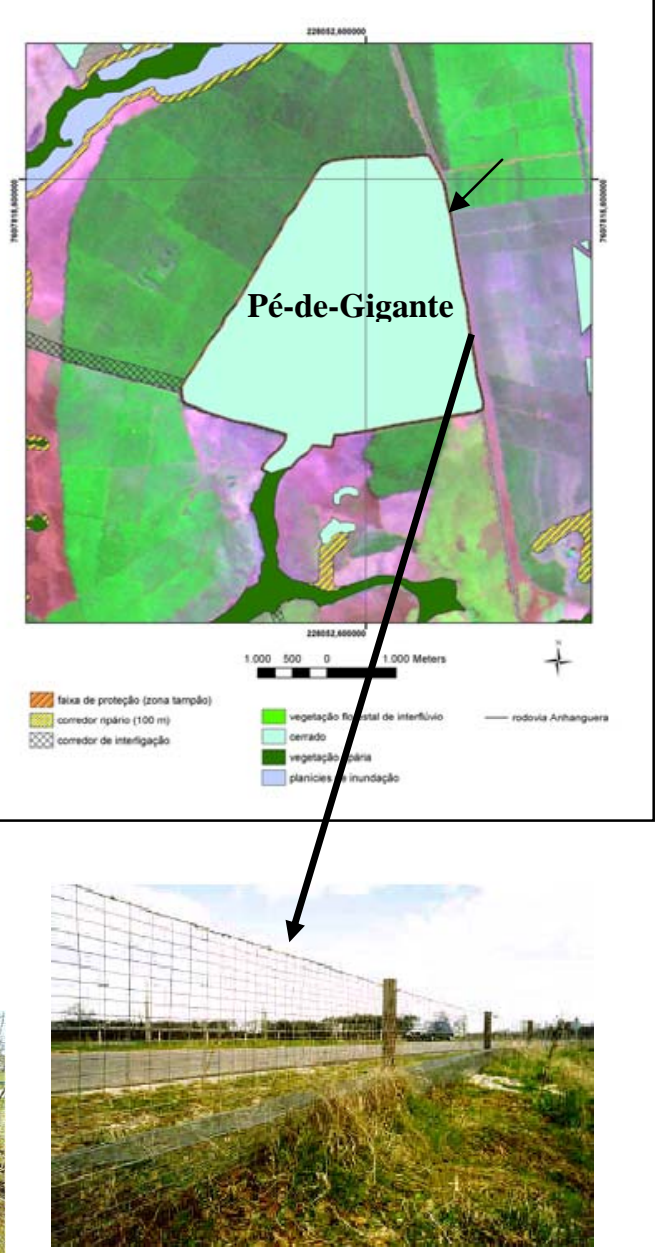

Fonte: (DNER/IME 2002)

Figura 35 - Indicação dos locais prioritários para se implantar dispositivos viários de proteção à fauna silvestre. 
Recomenda-se, portanto, que o entorno dos túneis e passagens seja reflorestado com espécies arbóreas e arbustivas e/ou trepadeiras (espécies nativas de ocorrência na região e que não ofereçam risco de proliferação e/ou invasão dessas espécies para o interior das glebas do PEV). Pesquisas devem ser realizadas para a escolha das espécies mais adequadas.

O objetivo de vegetar as entradas/saídas destas passagens, preferencialmente interligando outros fragmentos florestais próximos, é evitar ou diminuir a predação (ataque de animais predadores, como grandes mamíferos, gaviões, etc). Quanto a predação pelo homem (caça), esta deve ser mitigada pela implantação de uma fiscalização ambiental eficiente e, principalmente, a conscientização ambiental. A implantação de mais de uma passagem por rodovia também seria uma medida para diminuir a predação.

Além das passagens para proteger a fauna silvestre e, considerando a destruição de uma nascente que abastecia a gleba Capetinga Leste após a implantação da rodovia Anhanguera, procedimentos emergenciais devem ser tomados, entre os quais:

- A análise e estudos técnicos para melhorar os sistemas de escoamento das águas pluviais que necessitam ser reestruturados ou eliminados, pelo fato de promoverem o assoreamento dos corpos d'água e o surgimento de voçorocas. Instituições públicas, como o IPT - Instituto de Pesquisas Tecnológicas, possuem técnicos capacitados para orientar e divulgar tecnologias adequadas aos proprietários e empresários da região;

- Dispositivos para reduzir a velocidade na rodovia Anhanguera e vias vicinais e a implantação de placas ou painéis eletrônicos explicativos sobre a proximidade de uma Unidade de Conservação, bem como sobre suas características e importância ambiental. Estas propostas objetivam reduzir os riscos de acidentes e atropelamentos, servindo também de instrumento de divulgação do Parque e dos recursos naturais da região; 
- Transformação da rodovia Anhangüera, no trecho próximo às glebas Capetingas Leste e Oeste, em "estrada parque" (no trecho aproximado de 3,0 km, no limite da extensão das glebas até o quilômetro 2.42 da rodovia); ou mesmo o desvio desta rodovia no trecho próximo a estas glebas e à gleba Péde-Gigante. Apesar da complexidade e prováveis dificuldades em transformar a rodovia Anhangüera em "estrada parque" ou a construção de um novo trecho distante das glebas do Parque, é importante que se registre no presente estudo, condições que seriam mais adequadas ou ideais, não apenas para a conservação destes fragmentos e a diminuição dos atropelamentos da fauna, mas também, como instrumentos de divulgação e de educação e conscientização ambiental. No Brasil, um exemplo de estrada-parque é a Estrada-Parque do Pantanal, com 120 km de extensão, que liga a cidade de Corumbá (MS), ao entroncamento da BR-262.

h) Diretrizes de parcelamento do solo para as áreas de expansão urbana

Deve-se contemplar, tanto no Plano de Manejo do PEV como no Plano Diretor ou em leis municipais de parcelamento do solo dos municípios de Santa Rita do Passa Quatro e Luiz Antônio, algumas diretrizes para prevenir os impactos causados pelo crescimento urbano sobre o PEV. Pires et al. (2000) definiram para o entorno do Parque Estadual de Jataí, distante cerca de 3,5 km do PEV, uma área crítica periurbana, em que seria permitido somente o loteamento para a implantação de chácaras e sítios de lazer, com baixa densidade de ocupação e área mínima de 5 ha, não sendo permitido o uso industrial. Qualquer atividade potencialmente prejudicial à biota do referido Parque deverá ser obrigatoriamente licenciada pelo órgão ambiental com prévia autorização da administração da Unidade de Conservação.

Estas diretrizes podem ser adotadas para as áreas de expansão urbana próximas ao PEV; portanto, as atividades permitidas ou não nas áreas de entorno ou de expansão urbana, devem estar definidas e descritas no Plano de Manejo e/ou planos diretores ou leis municipais. 
Quanto ao tamanho ou área mínima para os lotes de chácaras ou sítios, é fundamental que vários estudos científicos sejam realizados, principalmente relativos à fauna silvestre, aos recursos hídricos e à vegetação nativa. Tão importante quanto a preocupação com o tamanho de lotes e densidade de ocupação, deve ser a preocupação com a distribuição espacial, a manutenção e/ou a implantação de corredores de interligação, o aumento e eficiência na fiscalização ambiental e o desenvolvimento de programas de conscientização ambiental.

As propostas indicadas nesta segunda etapa, com a indicação de procedimentos para serem implantados nas glebas do PEV, a implantação de corredores, além das propostas para a matriz de entorno, são estratégias que conciliam a conectividade da paisagem (com a interligação das glebas e de outros remanescentes de vegetação nativa), a restauração de habitats, aumentando-se a porcentagem de vegetação nativa na área de estudo e a proteção dos mananciais e corpos d'água da região. 


\section{CONCLUSÕES}

Apesar da importância ambiental e econômica (com a geração de benefícios para a região provenientes do turismo ecológico, por exemplo), o Parque Estadual de Vassununga encontra-se isolado em uma paisagem fragmentada, sofrendo forte pressão das áreas de entorno, decorrentes de várias atividades incompatíveis com a manutenção e conservação dos recursos naturais, além de problemas relativos à falta de recursos financeiros e de infraestrutura, incluindo problemas fundiários.

As propostas para reverter a atual realidade e que foram indicadas neste estudo são emergenciais: ressalta-se a necessidade de mais estudos e pesquisas sobre a influência e dimensão dos efeitos de borda, estudos sobre a fauna (espécies mais ameaçadas, espécies-chave, formas de deslocamento, etc) e a realização de levantamentos mais detalhados sobre a viabilidade de se implantar as propostas descritas neste estudo, principalmente as indicadas na segunda etapa.

As propostas correspondentes à primeira etapa - a interligação das glebas do PEV por meio do cumprimento da legislação ambiental - não deveriam fazer parte deste estudo, pois estão previstas na legislação ambiental (federal e estadual), incluindo a Constituição da República e do Estado de São Paulo e, portanto, correspondem aos direitos e deveres ambientais de todos os cidadãos.

Respeitar as áreas de preservação permanente, por exemplo, irá promover uma paisagem mais permeável e com uma maior conectividade entre as glebas do PEV. No entanto, verificou-se, neste estudo, o atual estado de degradação 
dos ecossistemas do PEV e região, o isolamento de suas glebas, a baixa porcentagem de habitats nativos na área de estudo e a degradação dos recursos hídricos. Diante desta realidade, esforços devem concentrar-se na implantação das propostas indicadas na segunda etapa. O manejo das unidades estruturais da paisagem, com propostas de conservação para as glebas do PEV (aumentando-se as suas áreas, diminuindo os efeitos negativos de borda), a implantação de corredores e pontos de ligação, a alteração dos usos das terras, acompanhados de ações políticas públicas (assistência técnica e financeira pelos órgãos responsáveis, programas de conscientização ambiental, programas públicos de incentivos aos proprietários que realizarem ou implantarem em suas propriedades/empresas projetos de recuperação e/ou conservação ambiental), são essenciais para que o Parque Estadual de Vassununga e os demais ecossistemas naturais da região possam cumprir suas funções ambientais, assegurando para a região de estudo, benefícios biológicos, físicos, econômicos e sociais.

A luta pela manutenção da biodiversidade não deve ser isolada, ou restrita a unidades públicas de conservação, pois, conforme observado no diagnóstico da área de abrangência deste estudo, as iniciativas de conservação que centradas apenas na unidade de conservação, ignorando a matriz, terão sempre sucesso limitado. A perda de espécies que ocorrem na região é percebida também pela população local. Jorge (1999), por meio de entrevistas junto à população local, verificou que todos os entrevistados afirmaram que a quantidade de animais diminuiu com a degradação do cerrado, acarretando, inclusive no desaparecimento de algumas espécies como a ema (Rhea americana), a onça-pintada (Panthera onca), o queixada (Tayassu pecari) e a anta (Tapirus terrestris).

É importante destacar que as espécies não existem de forma isolada e, quando uma espécie desaparece ou é extinta, podem desaparecer várias outras espécies associadas a esta, ocorrendo sérias alterações no ecossistema. Muitas destas perdas e alterações não são percebidas, 
conhecidas ou registradas a curto prazo, e nem sequer sabemos como poderão nos afetar.

Pires (1999) alerta para o fato de ainda desconhecermos a capacidade em amortizar os impactos ambientais e o papel da biodiversidade na manutenção das funções ecológicas importantes para assegurar a saúde e integridade dos sistemas ambientais.

O custo econômico para recuperação e conservação dos recursos naturais é elevado e requer tecnologias específicas (muitas das quais faltam estudos e pesquisas). É de fundamental importância despertar a consciência das autoridades públicas e privadas para o fato de que a implantação de procedimentos e dispositivos conservacionistas possui custos relativamente baixos quando comparados aos serviços ambientais e benefícios biológicos, sociais e econômicos proporcionados pela conservação dos recursos naturais do Parque Estadual de Vassununga e da região.

Outra visão que deve ser expandida, e talvez seja menos egoísta do que a preocupação em relação aos benefícios ou serviços ambientais e econômicos que os recursos naturais propiciam para a atual geração, é a de que devemos, ao menos, ter a preocupação moral e ética de entregarmos para as gerações futuras um mundo com a mesma diversidade biológica que nos foi entregue. 


\section{REFERÊNCIAS BIBLIOGRÁFICAS}

BATALHA, M.A. Análise da vegetação da ARIE cerrado Pé-de-Gigante (Santa Rita do Passa Quatro, SP). São Paulo, 1997. 185p. Dissertação (Mestrado) - Instituto de Biociências, Universidade de São Paulo.

BEIER, P.; NOSS, R.F. Do habitat corridors provide connectivity. Conservation Biology, v.12, p.1241-1252, 1998.

BENNETT, A.F. Habitat corridors and the conservation of small mammals in a fragmented forest environment. Landscape Ecology, v.4, p.109-122, 1990.

BERTONI, J.; LOMBARDI NETO, F. Conservação do solo. 2.ed. São Paulo: Ícone, 1990. 355 p.

BERTONI, J.; LOMBARDI NETO, F. Conservação do solo. São Paulo: Livroceres, 1985. $392 \mathrm{p}$.

BIERREGAARD JÚNIOR, R.O.; STOUFFER, P.C. Understory birds and dynamic habitat mosaics in amazonian rainforests. In: LAURANCE, W.F.; BIERREGAARD JUNIOR, R.O. (Ed.). Tropical Forest Remnants: Ecology, management, and conservation of fragmented communities. Chicago: The University of Chicago Press, 1997. cap. 10, p.138-155.

CARNEIRO, P.H.M. Caracterização florística, estrutural e da dinâmica da regeneração de espécies nativas em um povoamento comercial de Eucaliptus grandis em Itatinga, SP. Piracicaba, 2002. 131 p. Dissertação (Mestrado) - Escola Superior de Agricultura "Luiz de Queiroz", Universidade de São Paulo. 
CASTRO, A.G. Técnicas de sensoriamento remoto e sistemas geográficos de informações no estudo integrado de bacias hidrográficas. São José dos Campos, 1992. 145 p. Dissertação (Mestrado) - Instituto Nacional de Pesquisas Espaciais.

CERRI, C.E.P. Mapeamento das áreas de risco de erosão dos solos da bacia do rio Piracicaba. Piracicaba, 1999. 89 p. Dissertação (Mestrado) - Escola Superior de Agricultura "Luiz de Queiroz", Universidade de São Paulo.

CHIARELLO, A.G. Conservation value of a native forest fragment in a region of extensive agriculture. Revista Brasileira de Biologia, v.60, n.2, 2000.

CLERGEAU, P.; BUREL, F. The role of spatio-temporal patch connectivity at the landscape level: an example in a bird distribution. Landscape an Urban Planning, v.38, p.37-43, 1997.

COLLINGE, S.K. Ecological consequences of habitat fragmentation: implications for landscape architecture and planning. Landscape an Urban Planning, v.36, p.59-77, 1996.

COLLINGE, S.K. Spatial arrangement of habitat patches and corridors: clues from ecological field experiments. Landscape and Urban Planning, v.42, p.157-168, 1998.

COUTINHO, L.M. Ecological effects of fire in Brazilian cerrado. In: HUNTLEY, B.J.; WALKER, B.H. (Ed.). Ecology of Tropical Savannas. Berlin: SpringerVeralg, 1982, p.273-291.

DEPARTAMENTO DE ÁGUAS E ENERGIA ELÉTRICA DO ESTADO DE SÃO PAULO. Dados Mensais de precipitação da estação C4-095 - Usina Santa Rita, Bacia Turvo - 1971 a 1999. Santa Rita do Passa Quatro, SP. http://www.daee.sp.gov.br/srvicos/bancodados.htm (12 jun. 2001) 
DEPARTAMENTO NACIONAL DE ESTRADA DE RODAGEM, Ministério dos Transportes/Instituto Militar de Engenharia, Ministério da Defesa. Projeto de ampliação da capacidade rodoviária das ligações com os países do mercosul BR-101 Florianópolis (SC) - Osório (RS). Projeto Básico Ambiental. Tomo $\mathrm{V}$ - Subprograma de proteção à fauna. http://www.ime.eb.br/dner (27 fev.2002)

DERNARDIN, J.E. Erodibilidade do solo estimada por meio de parâmetros físicos e químicos. Piracicaba, 1990. 114 p. Tese (Doutorado) - Escola Superior de Agricultura "Luiz de Queiroz", Universidade de São Paulo.

EMBRAPA. Centro nacional de Pesquisa de Solos. Sistema brasileiro de classificação de solos. Brasília: EMBRAPA, 1999. 412 p. Produção de Informação.

ENVIRONMENTAL SYSTEM RESEARCH INSTITUTE. ArcView GIS version 3.1., Redlands, CA: ESRI, 1998. 340 p.

ENVIRONMENTAL SYSTEM RESEARCH INSTITUTE. ArcView GIS version 8.1., Redlands, CA: ESRI, 2002.

FONTES, M.A.L. Unidades de Conservação. Lavras: Universidade Federal de Lavras - FAEP, 2001. 46 p.

FORMAN, R.T.T. Land Mosaics: the ecology of landscape and regions. UK: Cambridge University Press, cap.1, 1997. p.3-40.

FORMAN, R.T.T.; COLLINGE, S.K. Nature conserved in changing landscape with and without spatial planning. Landscape and Urban Planning, v.37, p.129-135, 1997.

GASCON, C.; LOVEJOY, T.E.; BIERREGAARD JUNIOR, R.O.; MALCOLM, J. R.; STOUFFER, P.C.; VASCONCELOS, H.L.; LAURANCE, W.F.; ZIMMERMAN, B.; TOCHER, M; BORGES, S. Matrix habitat and species richness in tropical forests remnants. Biological Conservation, v.91, n.2/3, p.223-229, 1999. 
GUSTAFSON, E.J.; GARDNER, R.H. The effect of landscape heterogeneity on the probability of patch colonization. Ecology, v.77, n.1, p.94-107, 1996.

HARRIS, L.D.; SILVA-LOPEZ, G. Forest fragmentation and the conservation of biological diversity. In: FIEDLER, P.L.; JAIN, S.K. Conservation Biology the theory and practice of nature conservation, preservation and management. London: Chapman and Hall, 1992. p. 197-238.

HENEIN, K.; MERRIAN, G. The elements of connectivity where corridor quality is variable. Landscape Ecology, v.4, p.157-170, 1990.

HESS, G.R.; FISCHER, R.A. Communicating clearly about conservation corridors. Landscape and Urban Planning, v.55, p.195-208, 2001.

HICKEY, R.; SMITH, A.; JANKOWSKI, P. Slope length calculations from a dem within ARCINFO Grid. Comput. Environmental and Urban System, v.18, n.5, p.365-380, 1994.

IBAMA. Instituto Brasileiro do Meio Ambiente e dos Recursos Naturais Renováveis (a). 2003. IBAMA on line. http://www.ibama.gov.br/ (06 jan.2003) IBAMA. Instituto Brasileiro do Meio Ambiente e dos Recursos Naturais Renováveis (b). 2001. IBAMA on line. http://www.worldbank.org (24 jun.2002) INPE - Instituto Nacional de Pesquisas Espaciais. Curso de Hidrologia Florestal: erosão e sedimentação e sua relação com florestas. cap. 8, INSTITUTO BRASILEIRO DE GEOGRAFIA E ESTATÍSTICA. Luis Antônio: Carta do Brasil, Folha SF-23-V-C-IV-2, Escala 1:50:000, 1971.

INSTITUTO FLORESTAL. Informações sobre o Parque Estadual de Vassununga. Coordenadoria de Informações Técnias, Documentação e Pesquisa Ambiental. Secretaria Estadual do Meio Ambiente, 5 p, s/d.

INSTITUTO FLORESTAL. Secretaria Estadual do Meio Ambiente. http://www.iflorestsp.br/ (24 jun.2002)

INSTITUTO DE PEQUISAS TECNOLÓGICAS. Mapa Geológico do Estado de

São Paulo, São Paulo: IPT, 1981. v.1. (Série Monografias, 6). 
JOHNSON, M.A.; SARAIVA, P.M.; COELHO, D. The role of gallery forests in the distribution of cerrado mammals. Revista Brasileira de Biologia, v.59, n.3, 9 p., 1999.

JORDÁN, F. A reliability-theory approach to corridor design. Ecological Modelling, v.128, p.211-220. 2000.

JORGE, M.C.L. Avaliação do potencial faunístico da ARIE - Área de relevante importância ecológica - cerrado Pé-de-Gigante, parque estadual de Vassununga, Santa Rita do Passa Quatro, SP, com base na análise de habitats. São Paulo, 1999. 83 p. Dissertação (Mestrado) - Instituto de Biociências, Universidade de São Paulo.

JORGE; M.C.L.; PIVELLO, V.R.; MEIRELLES, S.T.; VIVO; M. de. Riqueza e abundância de pequenos mamíferos em ambientes de cerrado e floresta, na reserva cerrado Pé-de-Gigante, Parque Estadual de Vassununga (Santa Rita do Passa Quatro, SP). Naturalia, v.26, p.287-302, 2001.

KRONKA, J.F.E. Áreas de domínio do cerrado no Estado de São Paulo. São Paulo: Secretaria do Meio Ambiente, Governo do Estado de São Paulo, 1998. $84 \mathrm{p}$.

LAL, R. Soil Erosion Impact on Agronomic productivity and environment quality. Plant Sciences, v.17, n.4, p.319-464, 1998.

LAURANCE, S.G.; LAURANCE, W.F. Tropical Wildlife Corridors: use of linear rainforest remnants by arboreal mammals. Biological Conservation, v.91, p.231-239, 1999.

LAURANCE, W.F. Edge effects in tropical forest fragments: application of a model for the design of nature reserves. Biological Conservation, v.57,p.205-219, 1991.

LAURANCE, W.F. Introduction and synthesis. Biological Conservation, v.91, p. 1001-107, 1999.

LAURANCE, W.F.; BIERREGAARD JUNIOR, R.O. (Ed.). Tropical Forest Remnants: Ecology, Management, and Conservation of Fragmented Communities. Chicago: The University of Chicago Press, 1997. 616 p. 
LEVY, M.C.T.C. Avaliação de cenários da produção agrícola visando a sustentabilidade do uso das terras de Piracicaba (SP) . Piracicaba, 1995. 104 p. Dissertação (Mestrado) - Escola Superior de Agricultura "Luiz de Queiroz", Universidade de São Paulo.

LIMA, M.G.; GASCON, C. The conservation value of linear forest remnants in Central Amazonia. Biological Conservation, v.91, p.241-247, 1999.

LOUZADA, J.N.C.; SOUZA, O.F.F.; BERG, E. Ecologia e manejo de fragmentos florestais. Lavras: Universidade Federal de Lavras-FAEP, 2001. 42 p.

MacARTHUR, R.H.; WILSON, E.O. The theory of island biogeography. Princeton: Princeton University Press, 1967. 203 p.

MACHTANS, C.; VILLARD, M.A.; HANNON, S.J. Use of riparian buffer strips as movement corridors by forest birds. Conservation Biology, v. 10, n.5, p.1366-1379, 1996.

MARINHO-FILHO, J.; CASTAL, M.L. Mamíferos das matas ciliares dos cerrados do Brasil central. In: RODRIGUES, R.R.; LEITÃO-FILHO, H. de F. (Ed). Matas Ciliares: conservação e recuperação. São Paulo: Universidade de São Paulo, FAPESP, 2000. cap.13, p.209-221.

MARTINS, F.R. O método de quadrantes e a fitossociologia de uma floresta residual do interior do Estado de São Paulo: Parque Estadual de Vassununga. São Paulo, 1979. 238 p. Tese (Doutorado) - Instituto de Biociências, Universidade de São Paulo.

MARTUSCELLI, P; OLMOS, F. Reconhecimento Preliminar da Fauna do parque Estadual de Vassununga e da Estação Ecológica do Jataí (Santa Rita do Passa Quatro - Luis Antônio, SP). Secretaria do Meio Ambiente, Coordenadoria de Informações Técnicas, Documentação e Pesquisa Ambiental do Instituto Florestal. Processo SMA 40.797, 1993. 
McGARIGAL, K.; MARKS, B.J. FRAGSTATS: special pattern analysis program for quantifying landscape structure. Portland, OR: U.S. Department of agriculture, forest service, pacific northwest research station, 122 p, 1995. (Gen. Tech. Rep. PNW-GTR, 351).

MEFFE, G.K.; CARROLL, C.R. (Ed.). Principles of Conservation Biology. Massachusetts, Sunderland: Sinauer Associates, 1994. 600 p.

MESQUITA, R.C.G.; DELAMÔNICA, P.; LAURANCE, W.F. Effect of surrounding vegetation on edge-related tree mortality in Amazonian forest fragments. Biological Conservation, v.91, p.129-134, 1999.

METZGER, J.P. Estrutura da paisagem e fragmentação: análise bibliográfica. In: Anais da Academia Brasileira de Ciência, Rio de Janeiro, 1999. Anais. Rio de Janeiro: v. 71, n.3-1, p. 445-463, 1999.

MINISTÉRIO DO MEIO AMBIENTE. Lei nº 9985 de 18 de julho de 2000. Diário Oficial, 19 jul. 2000. http://www.mma.gov.br (31 jan.2003)

MUNARI, D.P.; PIVELLO, V.R.; MEIRELLES, S.T. Uso de silvicultura de eucalipto no entorno da gleba "Cerrado Pé-de-Gigante" (Parque estadual de Vassununga, SP) pela mastofauna. In: CONGRESSO DE ECOLOGIA DO BRASIL, 5 Porto Alegre, 2001. Resumos. Porto Alegre: UFRGS, v.1, 2001.

MURCIA, C. Edge effects in fragmented forests: implications for conservation. Tree, v.10, n.2, p.58-62, 1995.

NAIMAN, R.J.; DÉCAMPS, H. The ecology of interfaces: riparian zones. Annual Review Ecology System, v.28, p.621-658, 1997.

NOHLGREN, E.; GUSTAFSSON, L. Vegetation Corridors: a literature review with comments from a Swedish forest perspective. Skog Forsk: The Forestry Research Institute of Sweden. 42 p., 1995. (Report n.1)

NOSS, R.F. Corridors in real landscapes: a reply to Simberloff. Conservation Biology, v.1, p.159-164, 1987.

NOSS, R.F. The Wildlands Project - Land Conservation Strategy. Wild Earth. Plotting a North America Wilderness Recovery Strategy, p.10-25, 1992.

ODUM, E.P. Ecologia. Rio de janeiro: Editora Guanabara, 1986. 434 p. 
OGATA, H. Manejo de Fragmentos de Floresta em Parque Municipal de São Paulo. In: SEMINÁRIO CIÊNCIA E DESENVOLVIMENTO SUSTENTÁVEL, São Paulo, 1997. Anais. São Paulo: USP/CNPq, 1997. p.45-47.

PIRES, A.M.Z.C.R. Diretrizes para a conservação da biodiversidade em planos de manejo de unidades de conservação. Caso de Estudo: Estação Ecológica de Jataí e Estação Experimental de Luiz Antônio. São Carlos, 1999. 208 p. Tese (Doutorado) - Centro de Ciências Biológicas e da Saúde, Universidade Federal de São Carlos.

PIRES, A.M.Z.C.R.; SANTOS, J.E.; PIRES, J.S.R. Zoneamento ambiental e plano de manejo para uma unidade da paisagem. Estudo de caso: Estação Ecológica de Jataí e Estação Experimental de Luiz Antônio. In: SANTOS, J.E.; PIRES, J.S.R. Estudos integrados em ecossistemas - Estação Ecológica de Jataí. São Carlos: RIMA, 2000,v.1, 346 p.

PIRES, J.S.R. Considerações sobre a estratégia de conservação "inter situ". Revista Holos, n.1, 1999. p.109-116 (compact disc).

PIVELLO, V.R.; SHIDA, C.N.; MEIRELLES, S.T.. Alien grasses in Brazilian savannas: a threat to the biodiversity. Biodiversity and Conservation, v.8, p.1281-1294, 1999.

RANIERI, S.B.L. Estimativa da erosão do solo em uma bacia hidrográfica no município de Piracicaba (SP), utilizando os modelos USLE e WEPP. Piracicaba, 2000. 95 p. Tese (Doutorado) - Escola Superior de Agricultura "Luiz de Queiroz", Universidade de São Paulo.

RODRIGUES, E. Efeito de bordas em fragmentos de floresta. Cadernos da Biodiversidade, v.1, n.2, p.1-6, 1998.

RODRIGUES, R.R.; GANDOLFI, S.; NAVE, A.G.; FARAH, F.T.; NOVAES, E.; PIROMAL, R.A.S. Programa de Adequação Ambiental das Áreas Agrícolas da Cia. Açucareira Vale do Rosário. São Paulo: USP, Departamento de Ciências Biológicas, Laboratório de Ecologia e Restauração Florestal, 2001. $122 \mathrm{p}$. 
RODRIGUES, R.R.; LEITÃO-FILHO, H. de F. Matas Ciliares: conservação e recuperação. São Paulo: EDUSP, FAPESP, 2000. 320 p.

ROSADO, S.C. da S.; CARVALHO, D. Biodiversidade e Conservação Genética de Espécies Arbóreas. Lavras: Universidade Federal de LavrasFAEP, 2001. $35 \mathrm{p}$.

ROSENFIELD, G.H.; FITZPATRICK-LINS, K. A Coefficient of agreement as a measure of thematic classification accuracy. Photogrammetric Engineering and Remote Sensing, v.52, p.223-227, 1986.

SÃO PAULO. Governo do Estado. Documentos Ambientais: Decreto 750 Mata Atlântica. Regulamentação para o Estado de São Paulo. 2.ed. São Paulo: Secretaria Estadual do Meio Ambiente. 49 p. 1997a.

SÃO PAULO. Ministério Público do Estado de São Paulo. Promotoria de Justiça do Meio Ambiente. www.mp.sp.gov.br (06 dez.2002)

SÃO PAULO. Secretaria do Meio Ambiente do Estado de São Paulo. Cerrado: bases para a conservação e uso sustentável das áreas de cerrado do Estado de São Paulo. São Paulo: Secretaria de Estado do Meio Ambiente. 113 p. 1997b. (Série Probio)

SHIDA, C.N. Levantamento da distribuição espacial e temporal dos elementos da paisagem e de seus determinantes, na região dos municípios de Luiz Antônio e Santa Rita do Passa Quatro (SP), como subsídio ao planejamento ambiental. São Paulo, 2000. 114 p. Dissertação (Mestrado) - Instituto de Biociências, Universidade de São Paulo.

SILVA, J.M.C.; BATES, J.M. Biogeographic patterns and conservation in the South American Cerrado: a tropical savanna hotspot. BioScience, v.52, n.3, p.225-233, 2002.

SIZER, N.; TANNER, E.V.J. Responses of woody plant seedlings to edge formation in a lowland tropical rainforest, Amazônia. Biological Conservation, v.91, n.2/3, p.135-142, 1999. 
TABARELLI, M.; BAIDER, C.; MANTOVANI, W. Efeitos da fragmentação na floresta Atlântica da bacia de São Paulo. Hoehnea, v.25, n.2, p.169-186, 1998.

TABARELLI, M.; MANTOVANI, W.; PERES, C.A. Effects of habitat fragmentation on plant guild structure in the montane Atlantic forest of southeastern Brazil. Biological Conservation, v.91, p.119-127, 1999.

TIEBOUT III, H.M.; ANDERSON, R. A. Comparison of corridors and intrinsic connectivity to promote dispersal in transient successional landscapes. Conservation Biology, v.11, n.3, p. 620-627, 1997.

USP. Universidade de São Paulo. Agência de Notícias. Coordenadoria de Comunicação Social. São Paulo. http://www.usp.br/agen/bols/2000/rede 517.htm. (26 nov.2002)

VIANA, V.M. Biologia e manejo de fragmentos florestais naturais. In: CONGRESSO FLORESTAL BRASILEIRO, 6, Campos de Jordão, 1990. Anais. São Paulo: SBS-SBEF, 1990. p.113-118.

WISCHMEIER, W.H.; JOHNSON, C.B.; CROSS, B.W. A soil erodibility monography for farmland and construction sites. Journal of Soil and Water Conservation, v.26, n.5, p.189-193, 1971.

WISCHMEIER, W.H.; SMITH, D.D. Predicting rainfall erosion losses: a guide to conservation planning. Washington: Department of Agriculture, 1978. 47 p. www.Itid.inpe.br/dsr/vianai/CursoHF/Capitulo8c.htm (14 jan. 2002)

ZAKIA, M.J.B. Identificação e caracterização da zona ripária em uma microbacia experimental: implicações no manejo de bacias hidrográficas e na recomposição de florestas. São Carlos, 1998. 99p. Tese (Doutorado) USP -Universidade de São Paulo, Escola de Engenharia de São Carlos.

ZANZINI, A.C. da S. Princípios de ecologia e manejo da paisagem para a conservação da fauna silvestre. Lavras: Universidade Federal de LavrasFAEP, 2001. 117 p. 